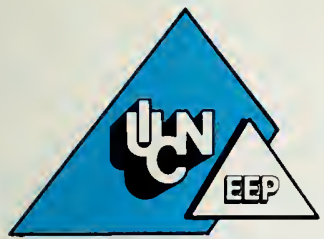

World Conservation Union

East European Programme

\title{
Protected Areas
}

\section{in Eastern and Central Europe and the USSR}

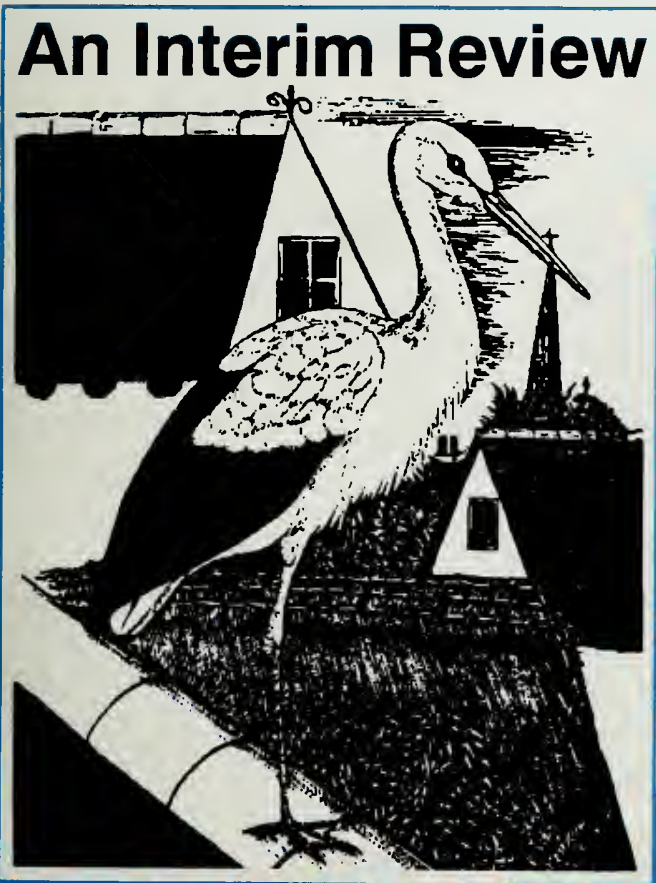

$$
x
$$$$
\text { sen- }
$$

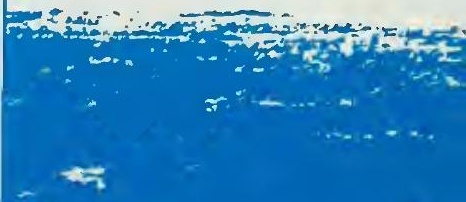

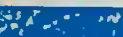

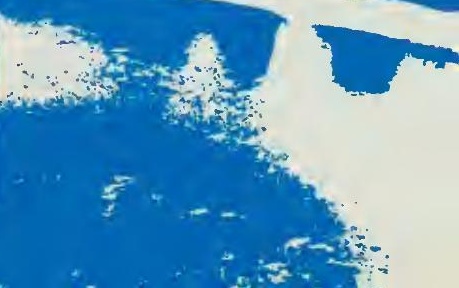


Digitized by the Internet Archive in 2010 with funding from UNEP-WCMC, Cambridge 
IUCN East European Programme

and

World Conservation Monitoring Centre

in collaboration with

IUCN's Commission on National Parks

and Protected Areas

\section{Protected Areas in \\ Eastern and Central Europe and the USSR \\ (An Interim Review)}


The views expressed in this volume do not necessarily reflect those of IUCN. Neither do the presentation of material and geographic designations employed imply any expression of any opinion whatsoever on the part of IUCN concerning the legal status of any country, territory or area, or concerning the delimitation of its frontiers or boundaries.

C 1990 International Union for Conservation of Nature and Natural Resources

Reproduction of material in this volume for educational and other non-commercial purposes is authorised without prior permission from the copyright holder.

Reproduction of material in this volume for resale or other commercial purposes is prohibited without prior permission of the copyright holder.

ISBN 2-8317-0038-8

Camera-ready copy and cover design by The Nature Conservation Bureau Ltd., 36 Kingfisher Court, Newbury, Berkshire, UK.

Printed by Information Press, Oxford, UK. 


\section{Contents}

Foreword.

Acknowledgements.....................................................................................................................

Country Accounts...................................................................................................................... 5

Albania, the People's Socialist Republic of....................................................................... 6

Bulgaria, the People's Republic of ................................................................................. 10

The Czech and Slovak Federative Republic................................................................... 17

The Eastern Länder of the Federal Republic of Germany

(formerly the German Democratic Republic)......................................................... 24

Hungary, the Republic of........................................................................................ 31

Poland, the Republic of................................................................................................... 37

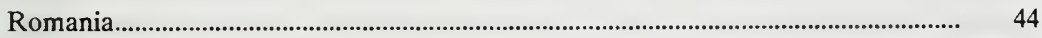

The Union of Soviet Socialist Republics.................................................................... 49

Yugoslavia, the Socialist Federal Republic of............................................................... 56

Protected Area List.......................................................................................................... 63

Albania, the People's Socialist Republic of..................................................................... 64

Bulgaria, the People's Republic of................................................................................ 65

The Czech and Slovak Federative Republic................................................................... 68

The Eastern Länder of the Federal Republic of Germany

(formerly the German Democratic Republic)..................................................... 71

Hungary, the Republic of ............................................................................................ 79

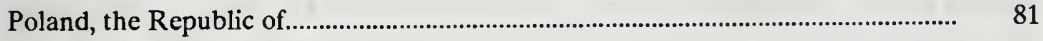

Romania..................................................................................................................... 84

The Union of Soviet Socialist Republics....................................................................... 87

Yugoslavia, the Socialist Federal Republic of.............................................................. 96 


\section{Foreword}

The changes that have transformed east and central Europe, politically and economically, have also resulted in a fresh evaluation of the state of the environment and the consequent need to restructure environmental policy. As we approach the end of 1990 there is continued uncertainty as to the final shape that this environmental policy will take. This fluid situation shows no sign of settling. Throughout the region environmental legislation, administration and management are in the process of evolution: different countries are changing at different rates. The IUCN's East European Programme, therefore, faced with a choice between waiting for all the changes to be finalised or of presenting a snapshot of the situation, one year after, chose the latter, in the full knowledge that what is written here will soon almost certainly be in need of updating. The opportunities to safeguard sites of biodiversity will also change (and disappear) rapidly. Witness the hectic rush to develop the previously closed and thus protected border areas, and the move to privatise and break-up existing protected sites. Hence the need to provide information, now.

This report is therefore seen as a contribution to efforts to ensure that those areas already protected remain and to secure new site of biodiversity within a network of protected areas.

The information for any one country has been compiled from a number of available sources and does not represent the views of any one individual. The information contained in this publication consists of standardised descriptions of the protected areas systems in each country using the best available information; a listing of protected areas qualifying for UN List status; and maps showing the known locations of national parks (a category which has seen a rapid increase in designations in the region).

\section{Acknowledgements}

The text has been compiled and edited by staff of IUCN's East European Programme and the World Conservation Monitoring Centre's Protected Areas Data Unit, by Robert Atkinson and Mark Spalding with assistance from Dr. Zbigniew Karpowicz. The maps were prepared by Crawford Allan. The protected areas lists were originally compiled by PADU for the 1990 UN list of National Parks and Protected Areas. 
Country Accounts

\section{Country Accounts}




\section{COUNTRY: People's Socialist Republic of Albania}

AREA $28,752 \mathrm{~km}^{2}$

POPULATION 3,200,000 (1989) Natural Increase $2 \%$ per annum

GNP US\$992 per capita (1988)

\section{POLICY AND LEGISLATION}

The Albanian Constitution proclaims that "The protection of the land, the natural resources and the waters from damage and pollution is a duty of the state and of all public and economic organizations, as well as of all citizens" (1976).

All land and natural resources are legally in the public domain, making all protected areas state property. Two relevant pieces of legislation are the Law on Forest Protection, No. 3349 of 3 October 1963, and the Law on Hunting, No. 1351 of 1 November 1951 (IUCN, 1967; Borisov et al., 1985). National parks are created under these laws.

Bogliani (1987) states that protected areas are classified into three categories. Parqet Nationale (National Parks) have the dual role of providing for public access, recreation and education, and for protection of the landscape. In national parks no permanent human occupation or exploitation is permitted. Hunting is prohibited and ancient grazing rights have been withdrawn, although villagers from neighbouring settlements are allowed to gather dead wood. Tourism is encouraged (IUCN, 1971). Each national park has a forest lodge for accommodation and vehicular access is permitted. Integral Reserves are strictly protected for nature conservation. A total protection regime is imposed, with no entry, occupation or exploitation permitted. Hunting is prohibited and ancient grazing rights have been withdrawn. Orientated Reserves provide for traditional human activities, education and protection of the landscape or wildlife. Recreational fishing is permitted (Bogliani, 1987).

\section{INTERNATIONAL ACTIVITIES}

Albania is party to the World Heritage Convention, which was ratified on 10 July 1990 . No natural sites have yet been inscribed on the World Heritage list. It also became party to the UNEP Regional Seas Programme (Barcelona Convention) in the same year, thereby 
completing the list of Mediterranean countries participating in this convention. Proposals for the inclusion of six coastal sites under the convention are being considered (J. de Grissac, 1990 pers. comm.).

\section{ADMINISTRATION AND MANAGEMENT}

There is a state body with responsibility for nature protection (Nowak, 1974), within the Ministry of Forest and Water Resources (IUCN 1971; Borisov et al. 1985). The Ministry of Agriculture is responsible for wetland conservation.

Within national parks, funds are allocated to cover salaries, as well as for reafforestation, other forestry programmes, civil engineering works, construction of pioneer camps, villas and infrastructures such as electricity and water supplies.

\section{SYSTEMS REVIEWS}

According to F. Markgraf (Davis et al. 1986), there arc four natural vegetation zones moving from east to west across the country, beginning with a narrow coastal strip in the west, now largely agricultural, but with some maquis, phrygana and secondary steppe. To the east of this lies a broad Mediterranean and transitional deciduous forest zone. European deciduous montane forests of beech Fagus sylvatica dominate the eastern mountain belt, with scattered patches of Macedonian pine (Pinus peuce). Finally, in the highest elevations along the Yugoslavian border, there is a subalpine and alpine zone.

The coast, which appears to be the least altered part of the country, is approximately $400 \mathrm{~km}$ in length and physically diverse. There are four large lakes (between 6,000ha and $35,000 \mathrm{ha}$ ) shared with Yugoslavia and/or Greece. All of these had significant waterfowl populations in the past, but their importance has greatly diminished as a result of extensive land reclamation and drainage. Similar strong pressures to convert land for agricultural purposes, coupled with a drive against malaria, have led to the drainage and reclamation of extensive areas of coastal marshes and lagoons. Between 1966 and 1970, 20\% of all capital investment was devoted to major hydrological projects. Drainage had already started in 1946 with the Maliq Lake and marshes. Between 1946 and 1974 some 60,000 ha of wetlands were drained and a further 170,000 ha were 'improved' for agricultural production; of the remaining 30,000 ha of coastal plains it is proposed that some 18,000 ha will be developed for agricuture and intensive fisheries in the future. Concern has been expressed (Imboden, 1990 , in litt.) over several new projects for soil improvement and land reclamation. Three of these overlap or adjoin coastal wetlands considered by the ICBP and IWRB to be of international importance (Kusse and Winkels 1990).

Water pollution is affecting fisheries and possibly flora and fauna; in the coastal plains 
the more important rivers are visibly polluted by industrial wastes and there has been a suggestion to establish 'river parks', similar to those in Greece (Prigioni et al., 1986) Many of the rivers in the coastal belt have been regulated and canalised.

Some $43 \%$ of the country's surface area is forested; some 16 million trees were planted in 1983. Forests are used for honey and silkworm production, with only small amounts of wood exported (Ellenberg and Damm, 1989). A major management proposal for 1987 was to combat erosion by further forestry development. The plan involved a national undertaking to expand and improve the forests. During December 1987 over 9 million saplings were to be planted, about $2,400 \mathrm{ha}$ of forest improved and $12,000 \mathrm{~km}^{2}$ of mountainous land protected (Anon., 1987).

\section{ADDRESSES}

- Ministry of Forest and Water Resources, Tirana, Albania.

- Secretary, Central Commission for Environmental Protection, The Council of Ministers, Tirana.

\section{REFERENCES}

Anon. (1987). ATA in English 0900 gmt 5 Dec 1987.

Bogliani, G. (1987). C'E'Del Verde in Albania - Riscopriamo una nazione che cambia. Airone, 74, June 1987, Italy.

Borisov, V.A., Belousova, L.S., Vinokurov, A.A. (1985). Okhranyaemye prirodnye territorii Mira. Natsional'nye parki, zapovedniki, rezervaty. Moskva, Agropromizdat.

Carp, E. (1980). Directory of Wetlands of Intemational Importance in the Westem Palaearctic. IUCN-UNEP-WWF, Gland, Switzerland. (unseen)

Cobani, J. (1988). Problems of state in protection of the atmospheric environment. (Abstract). Balkan Scientific Conference, Environmental protection in the Balkans. Varna, Bulgaria, 20-23 September, 1988. (unseen)

Davis, S. D., Droop, S. J. M., Gregerson, P., Henson, L., Leon, C. J., Lamlein

Villa-Lobos, J., Synge, H. and Zantovska, J. (1986). Plants in danger, what do we know?

IUCN, Gland, Switzerland, and Cambridge, UK. 461 pp.

Ellenberg, H. and Damm, K. (1989). Albanien 1989. Institut for Geographie, Technische Universitat Berlin. 384 pp.

IUCN (1967). Liste des Nations Unies des Parcs Nationaux et Reserves Analogues. IUCN, Brussels.

IUCN (1971). United Nations list of national parks and equivalent reserves. Second edition. 
Hayez, Brussels. (Translation from the French edition, 1967).

Karadimov, I. (1989). Balkan Mayors on the Environment. Sofia Press,Bulgaria. (unseen) Kusse, P.J. and Winkels, H.J. (1990). Remarks on desalination and land reclamation in the coastal area of the Peoples Socialist Republic of Albania. Dutch Ministry of Agriculture, Nature Management and Fisheries. 28 April 1990, unpublished report.

Mara, H. (1988). Des Problèmes de l'Etat et de la Protection del'Environnement Naturel en RPS d'Albanie. Environmental Protection in the Balkans. Balkan Scientific Conference. Varna, Bulgaria, 20-23 September, 1988. (unseen)

Nowak, E. (1976). Albania. In: Smart, M. (Ed.) Proc. Interm. Conf. on Conservation of Wetlands and Waterfowl, Heiligenhafen, Fed. Rep. of Germany, 2-6 December 1974. IWRB Publication, Slimbridge, England. Pp 67-72.

Prigioni, C., Bogliani, G., and Barbieri, F. (1986). The Otter Lutra lutra in Albania. Biological Conservation 36. Pp 375-383.

Wirth, H. (Ed.) (1979). Nature Reserves in Europe. Edition Leipzig, Leipzig, German Democratic Republic. 331 pp. (unseen)

DATE October 1987; reviewed October 1990 


\section{COUNTRY: People's Republic of Bulgaria}

AREA $110,911 \mathrm{~km}^{2}$

POPULATION $9,000,000$ (mid-1989 estimate) Natural Increase $0.1 \%$

GNP US\$ 7,129 per capita (Anon, 1990)

\section{POLICY AND LEGISLATION}

The Constitution refers to nature conservation under Article No.31 (1971). In Articles 22 and Article 23 of the Constitution proposals for designation of protected natural sites can be submitted by enterprises, institutions, organizations and by individuals.

Countryside protection dates from 1928 (Carter, 1977), when a 'union for nature protection': the Council for the Protection of the Countryside was formed. The first Conservation of Nature Act was issued in 1936 (Cerovsky, 1986). Little more was acheived during the war (1939-45) and in the ten years that followed. A nature protection decree was formulated on 27 August 1960 and brought into force by rules published on 5 June 1961, with the legislation applying equally to reserves and national parks (Article 7 of the Rules) (IUCN, 1971).

The 1967 Law on Nature Protection covers the preservation, restoration, rational use of nature and natural resources, monuments, historical sites, development of science and scientific research. This Law, and the 1969 Code of its Application, effectively repealed the Ordinance related to the protection of nature and the Decree of 1960.

The duties of all organisations and agencies in the field of flora, fauna and habitat protection are further defined in a number of acts including Protection of Air, Water Resources and Soil from Pollution (1963), Water (1969), Protection of Cultivated Lands and Pastures (1973) and Forests and Hunting and Fishery. Some other acts may also include relevant sections (ECE, 1986).

The Komitet za opazvane na prinodnata sreda (KOPS) (Committee for Environmental Protection) of the Council of Ministers was set up in 1976. KOPS declares a locality or an object under protection, by an order of the Committee's President, after consultation with the Academy of Science's Institute of Ecology and interested departments on whose territory the objects are located. These orders are published in the State Gazette. 
In 1977 a new document, entitled 'The Guidelines for the Protection and Reproduction of the Environment in the People's Republic of Bulgaria' was approved by State Council (Cerovsky,1986). This document covers environment preservation, restoration and management policies and now plays a central role in formulating state environmental policy (Stoilov et al, 1981). Another major policy document written in the early 1980s was the General Plan of the People's Republic of Bulgaria. This treats the environment as a complex integrated system. In particular the sections dealing with 'Recreation' and 'Standard Regional Planning Measures' refer to the important role played by legally protected areas (Mladenova and Paychev, 1985). Resources needed for protection measures are provided for in five-year and annual plans adopted by the Government and People's Assembly (Parliament) (ECE, 1986).

According to the 1967 Law there are five types of protected areas: nature reserves, national parks, nature sanctuaries, protected sites and historical sites. All land is state owned and reserve boundaries are marked with symbols and occasionally fenced.

Rezervat (nature reserves): these are areas strictly protected, containing rare plant and animal communities, threatened by depletion or extinction, and used for scientific research. Economic exploitation, including any agricultural and industrial activities, is prohibited. Admittance to, and movements in, reserves requires the approval of KOPS and is restricted to defined roads and paths. A special directive was adopted designating the creation of buffer zones around the reserves. In exceptional circumstances clear felling is allowed for forest protection reasons.

Naroden park (national parks): cover comparatively larger areas suitable for short-term recreation and tourism and for research. Other categories of protected areas may be included within the boundaries of national parks. National parks are also termed 'People's Parks' and tourism development is encouraged especially by state enterprises such as Balkan Tourist. Entry is free and unrestricted. Tourism may be well developed in the form of road networks, tourist chalets, resthouses, restaurants, cable cars and camping sites (IUCN, 1971). These areas have general protection throughout, with no settlement or exploitation allowed; hunting, fishing and flower-picking is forbidden. Some national parks are zoned into a scientific zone (no exploration, visitors restricted to certain paths), a tourist zone (accommodation, tree-felling and afforestation) and a commercial forest zone (IUCN, 1971).

Nature Sanctuaries: specific natural formations protected because of aesthetic and scientific significance, preserved for public interest due to national, geographic or scientific values as well as phenomena of aesthetic, natural or historical value, which includes single items, such as trees and rocks.

Protected Sites: specific locations with picturesque landscapes or characteristic habitats suitable for recreation. 
Historical Sites: the sites of major historical events, and historical monuments, graves as well as protected specific natural features of the landscape and their surrounding areas. Certain sites are protected jointly by KOPS and the Committee for Culture and the Institute for the Monuments of Culture (Stoilov et al., 1981).

\section{INTERNATIONAL ACTIVITIES}

The World Heritage Convention was signed on 7 March 1974 with two natural sites inscribed in 1983. The Ramsar Convention instrument was deposited on 24 September 1975 and the Paris Protocol instrument was signed on 27 February 1986; four sites have been designated. Seventeen sites, covering 25,201 ha, were registered as Biosphere Reserves by UNESCO in 1977. The Institute of Ecology is also active in international environmental conservation activities organized by UNESCO, UNEP, FAO and CMEA.

\section{ADMINISTRATION AND MANAGEMENT}

In 1971 the Ministry of Forests and Environmental Protection was established; this Ministry largely concentrated its attention on natural sites, establishing new reserves and improving those already in existence (Stoilov et al., 1981). In 1972 the Research and Coordination Centre for Preservation and Restoration of the Environment of the Bulgarian Academy of Sciences was established (Cerovsky, 1986).

In 1976 the Committee for Environmental Protection, the Komitet za opazvane na prirodnata sreda (KOPS), was set up at the Council of Ministers. This was the main governmental inter-departmental coordinating and controlling body, the President is of ministerial rank and the committee has 16 regional inspectorates and one scientific centre (Cerovsky,1986). It had the task of controlling, coordinating and implementing the policy and decisions of the Central Committee of the Bulgarian Communist Party, the National Assembly, the State Council and the Council of Ministers on questions of environmental protection and restoration and water resource utilization. The committee elaborates state plans on nature protection along with plans for research and development (ECE, 1986). The committee was also directed to establish a system to provide scientific data for matters relating to environmental protection - the Unified National System for Observation and Information on the State of the Environment was set up which includes a subsystem of 'Protected Natural Sites and Objects'. A card index on protected natural sites has been prepared by the committee, as well as sets of methods for a comprehensive study of protected natural sites and objects (Stoilov et al., 1981).

In December 1986 the ministerial council set up at the Council of Agriculture but was abolished in 1987 when the Ministry of Agriculture and Forests was created (Ashley, 1988). 
In the party congress of April 1986, the Bulgarian Communist Party committed itself to a new "National Programme for Environmental Protection to the Year 2000 and Afterwards". This was a long-term ecological programme which largely concentrated on the control and reduction of pollution control. In May 1988 a Politburo decision recommended that KOPS be merged with the Ministry of Agriculture and Forests to create the new Ministry of the Land, Forests and Environmental Protection (Ashley, 1988).

The Institute of Ecology, formerly known as the 'Research and Coordination Centre for the Conservation and Renewal of the Environment' (NKCOVOS), at the Academy of Sciences, has worked alongside KOPS in the designating of protected areas. It is a research institute with a staff of 60 who coordinate ecological research within the Academy of Sciences and with other scientific research establishments and universities (Cerovsky, 1986). It is also active in international environmental conservation activities. It maintains lists and data describing protected areas (Fisher, 1990).

Direct administration of protected areas falls to a number of bodies with varying levels of responsibility. These include Ministry of Forests and Forest Industry, Ministry of Architecture and Works, Balkan Tourist, Academy of Sciences, Nature Protection Commission, Ministry of Education, Committee of Arts and Culture, Academy of Agricultural Sciences and the Bulgarian Union of Hunters and Fishermen. Other organisations involved include the Standing Commission on Nature Protection of the People's Assembly and the Council on the Protection and Reproduction of the Natural Environment (within the State Council). The on-the-ground supervision of reserves is the responsibility of the forest administration and is carried out on a part-time basis by forest rangers. The control of reserves has been improved. Over 1200 checks were carried out in 1977 and 160 violations were notified, falling in 1978 to 1121 checks and 144 violations (Stoilov et al., 1981).

Voluntary environmental conservation groups were, until 1990, organized in the framework of the Patriotic Front, through a system of Committees for Nature Conservation at the Patriotic Front Councils on all levels. These were centralised in the All-National Committee for Nature Conservation at the National Council of the Patriotic Front, Obshchenarodniya Komitet za zashchita na prirodata, which promoted environmental awareness.

The Bulgarian Union of Anglers and Hunters is active in the role of conservation, while the Bulgarian Hiker's Union publicises natural sites within the country and promotes care of these sites (Stoilov et al., 1981). 'Ecoglasnost' is a non-governmental organisation set up in early 1989 with a particular interest in ecological problems. It has become a very influential movement and has been involved in a number of anti-pollution campaigns. In its 'Charter '89' Ecoglasnost devotes considerable space to its polices on protected areas, which it suggests should be greatly expanded, with numerous new areas being designated in all biogeographical regions. Ecoglasnost is made of local groups, about 50 in Sofia and 30 
in the rest of the country. There is a possibility it will become more involved in party politics in the future (Fisher, 1990). Recently, the Wilderness Fund, another non-governmental organisation, has been set up. It aims to further the conservation of natural areas and to facilitate the self-recovery of areas that have suffered human alteration (Ivanov, 1989).

\section{SYSTEMS REVIEWS}

The country straddles the boundary between continental and Mediterranean climates. It can be approximately divided into five regions: the fertile Danube plain in the north, running along the border with Romania; the Stara Planina Mountains, a large $600 \mathrm{~km}$ mountain chain running east-west, dividing the country; the central plain and valleys of the River Maritsa immediately south of the Stara Planina; the mountains of the Rila Planina, Pirin Planina and Rodopi Planina in the south-west and the relatively flat areas along the Black Sea coast (Grimmett and Jones, 1989). Lowlands $(0-200 \mathrm{~m})$ cover $31 \%$ of the total surface area of the country; hills $(200-600 \mathrm{~m})$ cover $41 \%$; highlands $(600-1600 \mathrm{~m})$ cover $25 \%$ and mountains (over $1600 \mathrm{~m}$ ) cover $3 \%$. The climax vegetation is Quercus up to $1000 \mathrm{~m}$, Fagus between 1000 and $1500 \mathrm{~m}$ and coniferous woodland up to $2200 \mathrm{~m}$, with some especially well-developed stands of Pinus peuce in the Rila, Pirin and Rodopi mountains.

Under the initiative of the 1928 Council for the Protection of the Countryside a number of bills and decrees were published and the country's first national park, Mount Vitosha, was declared in 1933. After this date few new areas were established until the 1960s. The total number of sites protected has risen from 50 in 1940 to about 130 in 1973 to 3922 in 1989. In 1989 these areas covered 195,155ha or nearly two per cent of the country (Anon., 1989). It is planned to increase this figure to three per cent by the year 2000 (ECE,1986). Zoogeographically, $77 \%$ of reserves belong to the Balkan and the Rila-Rhodopi Range. An inventory has been carried out of representative ecosystems covering areas over 1000 ha in separate reserves - over 20 forest formations have been catalogued. In 1982 forests covered $38,590 \mathrm{~km}^{2}$. (35\% of the land surface). More than $25 \%$ of forests are under special protection (ECE, 1986).

The main wetlands lie along the Danube and the Black Sea coast - many of the marshes and coastal lakes have been drained largely for agriculture; the remainder are particularly important for nigratory bird species. The north-eastern part of the Black Sea coast has some remnant steppe areas. The lowlands have largely been converted to agricultural land. In the uplands large areas have been devastated by grazing, mostly by sheep. Tourism and especially skiing are a potential threat to the remaining less disturbed upland areas (Grimmett and Jones, 1989). In certain regions (sea-coasts and mountains), as a result of urbanisation, road construction and increase in motor traffic and access to sites, there have been increases in the number of visitors to protected areas. Nature trails are popular and are being constructed first of all in protected areas. Threats arise partly from the lack of suffi- 
ciently severe penalties, or from the non-application of governmental decrees. Cattle grazing is still allowed in some nature reserves and poaching (hunting/fishing) continues to be prevalent in others.

\section{ADDRESSES}

- Komitet za opazvane na prirodnata sreda (Committee for Environmental Protection) 1000 Sofia, ul. Trialitza 2. Tel: 719138 . Telex: 22145 BANSF.

- Institute of Ecology, Academy of Science, ul Garagin 2, 1113 Sofia. Tel. 705498. Telefax: 803418 .

\section{REFERENCES}

Anon. (1989). Protected natural sites: invaluable national heritage. Committee for the Protection of the Environment with the Council of Ministers of the People's Republic of Bulgaria. ECO Facts and Figures. Sofia Press, Bulgaria.

Anon. (1990). PC Globe Inc., Tempe, Arizona, USA.

Ashley, S. (1988). Politburo Announces "New" Ecological Policy. Radio Free Europe. Vol. 13. No. 21. 27 May 1988. Pp.9-13.

Carter, F.W. (1978). Nature reserves and national parks in Bulgaria. L'Espace Geographique. No. 1. Pp.69-72.

Cerovsky, J. (1986). Nature Conservation in the Socialist Countries of East Europe. EastEurope Committee, IUCN Commission on Education. Administration of the Krkonose (Giant Mountains) National Park, Vrchlabi.

Cerovsky, J. (1988). Nature Consenvation in the Socialist Countries of East Europe. EastEurope Committee, IUCN Commission on Education. Ministry of Culture of the Czech Socialist Republic, Praha.

ECE (1986). Meeting Finland 25-29 August 1986. ENV/SEM. 16/R.1.

Fisher, D. (1990). Environmental Politics in Bulgaria. Report on a visit to Bulgaria 24-28 Febuary 1990. Ecological Studies Institute, Pentonville Road, London.

IUCN (1971). United Nations List of National Parks and Equivalent Reserves (2nd), Hayez. Brussels.

Ivanov, L. (1989). Memorandum of Association of the Wilderness Fund. Unpublished. Sofia, Bulgaria.

Johnson, H. and J.M. (1977). Environmental Policies in Developing Countries. Erich Schmidt, Verlag.

Mladenova, M. and Peychev, V. (1985). Concept of the General Plan of the Peoples Republic of Bulgaria on Legally Protected Areas. P. 40ff. Vol.1 in: Nedialkov, S. (1985). 
(Ed). Intemational Symposium 'Conservation of Natural Areas and of the Genetic Material They Contain' - Project 8, MAB-UNESCO 23-28 September 1985. Blagoevgrad, Bulgaria. Collection of reports Vol. I. 446p. Vol. II 380p. Vol. III 300p. Jusautor, Sofia. Profirov, L. (1989). Internationally recognised nature reserves. Bulgaria, Special Issue

(Eds. Gerassimov, P. and Staleva, M.). Sofia Press, Bulgaria.

Spiridonov, J. (1977). Oazisi na divata priroda (in Bulgaria). Zemizdat, Sofia. Stoilov, D., Noshtev, V., Gerasimov, S., Velev, V. (1981). Protected Natural Sites in the People's Republic of Bulgaria, Jurautor, Sofia.

DATE March 1987; reviewed October 1990 


\section{COUNTRY: Czech and Slovak Federative Republic}

AREA $127,870 \mathrm{~km}^{2}\left(78,860 \mathrm{~km}^{2}\right.$ of the Czech Republic and $49,010 \mathrm{~km}^{2}$ of the Slovak Republic)

POPULATION $15,600,000$ (mid-1989 estimate) Natural Increase $0.2 \%$ per annum

GNP US\$ 9,472 per capita (Anon., 1990)

\section{POLICY AND LEGISLATION}

The relevant section of the Constitution, relating to protected areas, is the Law No. 100/ 1960, Article 15. The first conservation of nature acts were introduced in the years 1955 and 1956.

The two republics have separate laws dealing with conservation: the State Nature Conservancy Act of 1955 - Law No. 1/SNR 1955 for the Slovak Republic, and the State Nature Conservancy Act of 1956 - Law No. 40/1956, for the Czech Republic. In 1986 the Czech and Slovak national councils enacted Laws No. $65 / 1986$ and No. $72 / 1986$ respectively, to impose penalties for offences against the State Nature Conservancy decrees of 1956. Republic acts are brought together and integrated by Federal legislation. In June 1990 a Commission for the Environment was set up at the federal level. The integration of natural resource conservation with economic activities is dealt with by sectors such as forests, water management, agriculture, mineral surveys, mining, industrial production and construction.

The State Nature Conservancy Acts at republic level define nature conservation as the preservation, renewal, enhancement and use of natural wealth and the special protection of important areas and natural features. These laws are supplemented by separate republic guidelines issued in 1978 and 1980 dealing with nature conservation development. The overall objective is to integrate conservation and use of natural resources and to apply principles of ecosystem conservation.

Protected areas were established under the 1955 and 1956 Acts by the respective Ministries of Culture. The Ministries of Culture decided on the establishment of all protected area categories with the exception of national parks which were also established under the 1955 and 1956 Acts by decrees of the Czech and Slovak National Councils. Regional National Committees give guidance to the District National Committees which are responsible for nature conservation, protected areas and the establishment of protected 
natural features and monuments at the district level (Marsakova and Skrivanek, 1982). There are three main categories of protected areas:-

Narodni parky (national park): these are defined as areas with very valuable natural resource, influenced little by human activity, with great climatic, health and recreational importance. National parks have complete protection, except for some forest exploitation which is strictly controlled. The parks are zoned with a 'controlled area' for recreational development which includes villages, holiday homes, sanitaria, camp sites and other facilities. Hunting is prohibited. National parks are fully open to visitors with the exception of access to strict nature reserves within the park. Tourism is regarded as a main objective of national parks.

Chranene Krajinne Oblasti (CHKO) (protected landscape areas): these are areas of lower natural values but with significant scenic and aesthetic qualities, they represent the harmonious interaction between natural components and traditional human activities. They aim to protect all values and typical features of the landscape and encourage the rational use of natural resources (Povolny, 1986). They are also used extensively for recreation (IUCN, 1971). Within CHKOs the most valuable parts are strictly protected as nature reserves or natural features. Although they are not excluded from further exploitation, all economic activities are carried out in accordance with the understanding of the republic-level nature conservation bodies. Projects dealing with water management, forest management, agriculture, industry, transportation, building, tourism and recreation, as well as exploitative activities such as mining, must be conducted in accordance with goals of the protected area and accordingly territorial planning is conducted, discussed and revised to be in line with this (Marsakova and Skrivanek, 1982). All CHKOs in the Slovak Republic have buffer zones (Wiltowski, 1979).

Statni Prirodni Rezervace (SPR) (national nature reserves): these are areas where the complete ecosystem is subject to conservation management (Marsakova and Skrivanek,1982) and are strictly protected areas of great scientific and research importance (IUCN, 1971).

A further five categories of protected areas are also used :-

Chranene Studijni Plochy (CHSP) (protected study areas): are small protected sites designated for research and teaching purposes.

Chranene Prirodne Vytvory Krasove Javy (CHPV) (protected natural features): are geological features, especially karst areas, as well as individual monumental trees.

Chranene Parky a Zahrady (CHPZ) (protected park or gardens): historic parks protected under the Cultural Monument Act. 
Protected Habitats: these are sites in which the occurrence of one or more plant or animal species are subject to preservation.

Chranene Naleziste (protected natural monuments): these are natural features documenting human activities or associated with historical events.

\section{INTERNATIONAL ACTIVITIES}

The Ramsar Convention was acceeded to on 2nd July 1990; eight sites have been designated. Six sites, covering 364,170ha, were registered as Biosphere Reserves by UNESCO by 1990 . The World Heritage Convention was signed in 1990 and tentative lists of sites for nomination are in the process of being drawn up in both Czech and Slovak republics.

\section{ADMINISTRATION AND MANAGEMENT}

In 1940 the Trust for Enhancement and Protection of Native Country was founded in Prague. The State Institute for Protection of Monuments and Conservation of Nature was established in Prague in 1958.

The administration of protected areas was the responsibility of the respective Ministry of Culture in each republic, with the central conservation authority within these Ministries being the Department for Nature Conservation. From 1988 a new Ministry of Interior and Environment was established in each republic. This was the central authority for the management of the environment, as well as for co-ordinating and controlling environmental functions of other ministries.

In June 1990 a federal level State Commission for the Environment was set up, headed by the Federal Environment Minister. There are four departments: legislation and landscape planning, policy, projects and international cooperation. At the republiclevel a Czech Ministry was established by act of the National Assembly No 173/1989 and was defined as the highest state control authority in environmental protection. It is responsible for water, air and nature protection as well as land protection aspects of agriculture and forestry and mineral resource protection. A Slovak Commission was established by act of the Slovak national assembly, No 96/1990 in March 1990. It has authority to carry out administration of nature conservation, but not forestry, land use and mineral resource issues. The republican ministries will concentrate on executive and inspection functions, while the federal commission will concentrate on forward planning and strategy. A 13-member Federal Committee for the Environment, headed by the Federal Environment Minister, was also set up in 1990 which meets regularly to discuss environmental matters (Fisher, 1990). 
At the federal level, the environment was controlled by the State committee for scientific, technical and investment development (Stani Komise Provedecky, Technicky a Investicni Rezvej) acting through the Czech Centre for State Protection of Monuments and Nature Conservation (Ustredi statni pamatkove pece a ochrany prirody SUPPOP) and the Slovak Centre for State Nature Conservation (Ustredie statnej ochrany prirody USOP) (Cerovsky, 1988). Before 1990 there were eleven Regional Centres for Protection of Monuments and Conservation of Nature which had representatives present from the nature protection departments (IUCN, 1971). A Council for Environment acted as an advisory and consultative body for both republics and dealt with the key problems of natural resource conservation (Marsakova and Skrivanek, 1982; Cerovsky, 1988). A key exercise was the preparation and revision every ten years of a special planning document, the 'territorial project of nature conservation' which was elaborated for all national parks and protected landscape areas (Povolny, 1986; Cerovsky, 1988).

From 1990, the SUPPOP was restructured as the Czech Institute for Nature Conservation Cesky Ustav Ochrany Prirody (CUOP) with an equivalent Slovak Institute for Nature Conservation Slovensky Ustav Ochrany Prirody (SUOP) replacing USOP. The main aim of the two institutes continues to be the selection, management and use of protected natural components. They are also likely to continue to carry out wide-ranging research on threats to protected areas, monitoring and basic inventory work for each protected area and prepare management plans (Marsakova and Skrivanek, 1982).

The Ministry of Forest and Water Management and Timber Industry is responsible for water and atmospheric conservation, pollution control, forest management and conservation. In the Czech Republic, respective District National Committees declare, in accordance with territorial plans, 'quiet areas' where motor vehicles, camping and other recreational activities are prohibited.

The administration and management of the national parks tend to vary from site to site. For example, the High Tatra National Park is under the direct responsibility of the Slovak Ministry of Forest and Water Management, while the authority which runs this park is also responsible for the running of the Pieninsky National Park. The Krkonosze National Park is subordinate to the East-Bohemian Regional National Committee. Many of the frontier national parks and protected areas are organized on a bilateral basis.

Protected Landscape Areas (CHKOs) are administered by separate offices for each area which deal directly with the local and regional authorities (Wiltowski, 1979, Karpowicz, pers. comm. 1990). They employ an average of four to ten professional staff, who are principally involved in planning, managment, monitoring and eduational work. Research in CHKOs is conducted by the Academies of Science or by the Research Institutes of the competent ministry. In the Czech republic CHKOs are likely to be supervised by the Institute for Nature Conservation (J. Cerovsky, 1990, pers. comm.). In the Slovak Republic, 
CHKOs are administered by the Slovak Institute for Nature Conservation.

In 1969 the Slovak Union of Nature and Landscape Conservationists (Slovensky svaz ochrancov prirody a krajiny) (SZOPK) was founded with 14,000 individual members, over 400 collective members, 260 local groups and more than 600 youth groups with 11,000 members; and the Czech Union of Nature Conservationists (Cesky svaz ochrancu prirody) (CSOP) was founded ten years later in 1979 with 24,000 individuals, over 350 collective members and 768 local groups (Cerovsky, 1988).

\section{SYSTEMS REVIEWS}

Most of the Slovak Republic is mountainous as are the northern and southern boundaries of the Czech. Agricultural land covers $69,000 \mathrm{~km}^{2}$ ( $54 \%$ of the land surface): $48,000 \mathrm{~km}^{2}$ of this are arable, $8,000 \mathrm{~km}^{2}$ are meadow and $8,000 \mathrm{~km}^{2}$ are pasture. Much of the remaining area of the country is covered by forest, with broad-leaved deciduous forest (and extensively reafforested areas of Picea and Pinus) at lower altitudes, giving way to mixed coniferous and deciduous woodland at higher altitudes, and Pinus in subalpine zones. The forests, particularly in the northwest are among the worst affected by air pollution in Europe. In warmer areas, close to the Hungarian border, there are remains of steppe-woodland and steppe-grassland vegetation (Grimmett and Jones, 1989).

Land is in the most part under state ownership, but where private enclaves occur in protected areas the owners are obliged to conform to legal requirements.

On the basis of the document The Environment in Czechoslovakia (Vavrousek, 1990) in June 1990 a 'Draft concept of state ecological policy' was produced (Vavrousek et al., 1990a) which described future potential policy directions. This was followed in July 1990 by the document Ecological Programmes and Projects, Czech and Slovak Federative Republic (Vavrousek et al., 1990b) which added the details to the policy and described specific objectives including the development of national and international parks.

Major environmental threats are from acid precipitation and agricultural mechanisation. The Czech Ministry of Environment, through its state nature conservation bodies, has an advisory input to discussions regarding state and republic plans, agricultural and water management and energy projects and all types of physical planning. In response to environmental crises a national plan - 'the eco-programme' - was being developed, aimed at integrating ecology and economic activities (Cerovsky, 1986). A national conservation strategy was also being prepared and contains a Species Preservation Strategy for the Czech Republic.

Total protected area is given as $10,869 \mathrm{~km}^{2}$ in the Czech Republic $(13.8 \%)$ and $8,163 \mathrm{~km}^{2}$ in the Slovak Republic (16.7\%) Cerovsky, 1988). 
The first recorded establishment of protected areas was in 1838 when two forest reserves were created in south Bohemia, followed by additional reserves in 1858 and 1884 . An ordinance giving protection to natural monuments was decreed in Slovakia in 1900. The first national park was created in the mountainous High Tatras in 1948, and the first protected landscape area (Cesky raj) in 1955. A plan for the development of the protected area network to the year 1990 envisages an increased area of 490,000 ha or an addition of $10 \%$ to the surface area (Wiltowski, 1979).

\section{OTHER RELEVANT INFORMATION}

Special governmental decisions were passed in 1976 and 1978 regarding environmental education which was to be promoted in both republics, at all levels. Some universities offer courses on 'Protection of the Natural Environment'. Selected protected areas are used very extensively for educational purposes and have visitor centres and nature trails. In the Slovak Republic a conservation training centre operates in Gbelany near Zilina and in the Czech Republic there is an establishment in the Krkonose National Park. The Centre for Nature Conservation Development in Bratislava has since 1982 published Chranene uzemia Slovenska-spravodajca a yearbook on protected areas in Slovakia.

\section{ADDRESSES}

\section{Federal}

- Federal Committee for the Environment, Slezska 9, 12029 Praha 2. Tel. 256488. Fax. 2152659. Telex. 121427.

\section{Czech Republic:}

- Ministerstvo Zivotniko Prostredi (Ministry of Environment CR) Lazarska 7, CS-110 00 Praha 1. Tel: 731357.

- Cesky Ustav Ochrany Prirody Valdstejnske nam e 1,11800 Praha 1. Tel. 5131770. Slovak Republic:

- Commission of the Environment 03101 Liptovsky Mikulas ulica 1. maja 43.

- Institute for Nature Conservation 03101 Liptovsky Mikulas ulica 1. maja 43.

\section{REFERENCES}

Anon. (1990). PC Globe Inc., Tempe, Arizona, USA.

Cerovsky, J. (1986). Nature Conservation in the Socialist Countries of East-Europe. EastEurope Committee, IUCN Commission on Education, Administration of the Krkonose 
(Giant Mountains) National Park. Vrchlabi.

Cerovsky, J. (1988). Nature Conservation in the Socialist Countries of East-Europe. EastEurope Committee, IUCN Commission on Education, Ministry of Culture of the Czech Socialist Republic, Praha.

Cerovsky, J and Petricek, V. (1985). Rukovet oclirance prirody. (Handbook of Nature Conservationists). Ministry of Culture of CSR, Praha. (not seen).

Fisher, D. (1990). Environmental policy in central Europe: some notes on a visit in July 1990. Unpublished report.

Grimmett, R. F. A., and Jones, T. A. (1989). Impontant Bird areas in Europe. International Council for Bird Preservation, Cambridge, UK. 888 pp.

IUCN. (1971). United Nations List of National Parks and Equivalent Reserves. (2nd) Hayez, Brussels.

Marsakova, M. (Ed.) (1983). Statni ochrona prirody v CSR. (State Nature Conservancy in the CSR). SUPPOP. Praha. (not seen).

Marsakova, M. \& Skrivanek, F. (1982). Conservation of Nature and Natural Environment in the Czechoslovak Socialist Republic. OBIS SUPPOP, Praha.

Marsakova-Nemejcova, M., Mihalik, S. et al. (1971). Naıdni parky, rezervace a jiha chranena uzemi prirody $v$ Ceskoslovensku. (National parks, reserves and other natural protected areas in Czechoslovakia). Academia, Praha.

Vavrousek, J. (1990). The Environment in Czechoslovakia. UTEIN, Praha.

Vavrousek, J., Moldan, B., Ondrus, V. et al. (1990a). Draft concept of state ecological policy. Unpublished document.

Vavrousek, J., Moldan, B., Tirpak, I. et al. (1990b). Ecological Programmes and Projects, Czech and Slovak Federative Republic. State Commission for Science, Technology and Investments; Ministry of Environment of the Czech Republic and Slovak Commission for Environment, Prague and Bratislava.

Wiltowski, J. (1979). Ochrana przyrody w Slowacji. Clıronmy PrzyrodeOjczysta. R. 35 z.l. Pp 46-52.

DATE March 1987; reviewed October 1990 


\section{COUNTRY: The Eastern Länder of the Federal Republic of Germany (FRG)}

formerly the German Democratic Republic (GDR). The reinstated Länder, superceded in July 1952 by the Bezirks system, are: Brandenburg, Mecklenburg, Saxony, Saxony-Anhalt and Thuringia (Sword 1990).

AREA $107,860 \mathrm{~km}^{2}$

POPULATION $16,766,000$ (UN 1985)

Natural Increase $0.1 \%$ per annum $16,600,000$ (1989 estimate)

GNP US\$ 11,754 per capita

\section{POLICY AND LEGISLATION: GDR}

The relevant sections of the East German constitution are Article No. 15, Item (1) and (2) (Cerovsky, 1988). The first law on Conservation of Nature was enacted in 1935. In 1954 the Conservation and Care of Native Nature came into force, to be replaced on 14 May 1970 by the first comprehensive environmental law - the Landeskulturgesetz (Culture of Country Act, full title 'PlannedCreation of the Socialist Country Culture in the German Democratic Republic'). As a consequence of this basic document on area protection, an ordinance covering species protection linked to habitat conservation (flora and fauna) was passed in October 1984.

Measures enacted by the 'post-revolution' government were aimed at preserving ecologically intact and unique habitats and supporting programmes for protection of endangered plant and animal species (Steinberg, 1990).

Up until November 1989 there were three categories of protected area:

Naturschutzgebiet, NSG (Natural Nature Reserve or Protected Area): areas established for the protection of a wide variety of species and ecotypes. Management was geared to nature conservation, although some rural land-use was allowed. Up to $6.7 \%$ of the total NSG area consisted of strict reserves purely for nature conservation.

Landschaftschutzgebiet, LSG (Landscape Protected Area or Reserve): areas estab- 
lished primarily for the protection of rural and scenic landscapes including geological features. Forest management and agricultural use occur throughout the designated LSGs (Cerovsky, 1986).

Flächennaturdenkmaler (Natural Monuments): are natural elements, such as geological features, ancient trees or natural objects often associated with historical events. They are classed as Naturdenkmäler (ND) if single natural objects or Flächennaturdenkmaler (FND) if a small area no greater than 3ha (Cerovsky, 1988).

\section{POLICY AND LEGISLATION: FRG}

Constitutionally a federal republic; the protected area categories, establishment procedures and responsibilities for nature conservation being defined in the nature conservation legislation at the province level (länder).

However, there are general legislative provisions for conservation such as the Federal Law on Nature Conservation (1976) which specifies Länder landscape programmes, regional landscape development plans, local landscape plans and their respective contents. General measures are set out for the protection, maintenance and development of nature and landscape. These measures also define which general activities and land uses are considered to be in conflict with nature and landscape. The Länder have adopted their legislation on nature conservation and physical planning in conformity with this Act (Holzner, 1986).

At present, existing or potential areas of nature or landscape interests are identified in the regional plans. These plans are based on complex negotiations sometimes lasting up to ten years or more between public authorities, institutions, interest groups and experts; they are led by the regional planning agencies attached to the Länder governments who act for the county planning associations, the members of which are the district and local authorities. The plans are enacted by Länder government orders. National parks and nature parks are established by the Länder; large-scale nature or landscape conservation areas by the counties; smaller ones by the districts. The conservation orders describe the site and its demarcation, and the reasons for its designation; they contain a set of prohibitions and list the activities for which permission is required and for which exceptions are granted. Depending on the type of conservation area, there are various restrictions on agriculture. These may preclude drainage, removal of landscape features, intensification, the construction of buildings or other permanent facilities, fencing and so on. Usually there are no compensation payments, but there may be grants for active conservation works.

There are five main types of protected areas: national parks, nature reserves, natural monuments/sites, protected landscapes and nature parks. Creation of reserves under the Nature Conservation Law does not exclude hunting and separate declarations of controlled 
hunting areas or non-hunting areas must be made under the Hunting Laws (Holzner, 1986). Apart from the different categories based on the legal provisions in the field of nature conservation, the forest administration of the Länder has designated small natural forest reserves and natural forest units. No silviculture takes place in these areas (Ertz, 1979).

\section{INTERNATIONAL ACTIVTTIES: GDR}

The instrument of the Ramsar Convention was deposited on 31 July 1978 with a total of eight sites designated. Under the Unesco MAB programme two sites were declared biosphere reserves in 1979, with six more proposed in September 1990. The GDR ratified the World Heritage Convention on 12 December 1988 but no natural sites have been designated.

The Society for Nature and Environment is a member organization of IUCN and of the East-Europe IUCN Commission on Education. The GDR also participated in the environmental activities of Unesco, UNEP and CMEA.

\section{INTERNATIONAL ACTIVITIES: FRG}

The Ramsar Convention was ratified on 26 February 1976, with to date 21 sites designated. The World Heritage Convention was signed on 23 August 1976, no natural sites are listed as yet. One Biosphere Reserve was designated in 1981.

\section{ADMINISTRATION AND MANAGEMENT}

Pre WWII Germany

In 1904, the first set of objectives and tasks for the care of natural monuments was formulated and in 1906 the first government nature conservation authority, the Prussian (later Central German) Board for Care for Natural Monuments, was established in Berlin (Cerovsky, 1988).

\section{$G D R$}

The supreme authority for nature conservation, including protected areas, was the Ministry of Agriculture, Forest Management and Food, with the regional authorities being the Regional Councils' Forest Management Departments in all 15 Bezirks. Research and advice was provided by the Institut für Landschaftsforschung und Naturschutz, (Institute for Landscape Survey and Nature Conservation of the Academy of Agricultural Sciences) cre- 
ated in 1953 with five regional branches at Dresden, Greifswald, Halle, Jena and Potsdam. The state nature conservation bodies often actively cooperated with voluntary bodies in programmes of species protection (Cerovsky, 1988).

In late 1989 a Ministry of Environment was created, to be replaced in 1990 by a Ministry for the Environment, Nature Conservation, Energy and Nuclear Safety. The change in structure also saw an increase in staffing levels (just 20 in 1989).

In 1904 the Bund Deutscher Heimatschutz (German Trust for Protection of the Native Country) was founded and continued to exist (in Saxony only) until the end of World War II. Other voluntary organizations include the Gesellschaft für Natur und Umwelt im Kulturbund der DDR (the Society for Nature and Environment in the Cultural Union of GDR) founded in 1980 and with 60,000 members. The modern ecological parties, such as the Green Party and Alliance 90, all have an interest in protected areas as a general element in preserving the environment.

Although the protected areas system of East Germany was extensive many sites have been degraded through use for military and economic purposes. The country is also littered with waste dumps and has one of the highest sulphur dioxide emissions in the world, these factors adding additional stress to the network of areas.

\section{FRG}

At the federal level the Department of Nature Protection, Environment and Health within the Ministry of Environment, Nature Protection and Nuclear Safety, is responsible for administration of nature conservation together with scientific and technical agencies. Nearly all nature reserves are established on private land and in most some form of land use continues. Relatively few sites (mostly bird reserves) have staff specifically employed for nature conservation purposes, their expenses tend to be paid from a general budget. The administration and management of nature reserves is the responsibility of the Councils for Nature Conservation and Landscape Management which work at local, district, Länder and federal administrative levels, advising the authorities concerned. National parks are administered by park authorities responsible to their respective Länder governments. 'The Federal Institute for Vegetation Research, Nature Conservation and Landscape Management with its Department of Nature Conservation is responsible for research and provision of advice to federal bodies.

A number of non-governmental organisations also own nature reserves, or parts of nature reserves, or have taken over management or wardening of reserves (especially bird reserves) (Ant and Engelke, 1973; Erzt, 1979; Holzner, 1986). 


\section{SYSTEMS REVIEWS: GDR}

Mostly an agricultural landscape. To the north, oak Quercus spp., beech Fagus sylvtica, and pine Pinus spp., comprise the main woodland cover, much of this having been replaced with conifer plantations. In the south there is a vertical zonation of oak and hornbeam Carpinus betulus forest which gives way to montane beech forests. Above $500 \mathrm{~m}$ there are forests of beech, fir and spruce (Davis et al. 1986). Forests cover $29,500 \mathrm{~km}^{2}$ (27\% of the country). Threats to the environment are largely from industrial and agricultural development.

The first protected site in the Eastern Länder area was established in 1852 at 'Teufelsmauer' (Devil's Wall) near Quedlinburg, followed in 1886 by the bird protection station at Seebach near Mulhasen (Cerovsky, 1988).

Total area protected is $2,068,000$ ha which is more than $19 \%$ of the surface area of the country, classified as 766 natural protected areas and covering 104,000 ha (of which 6,980 ha were strict reserves); 404 landscape protected areas, covering 1,964,000ha; and 9,500 natural monuments, covering over 4,000ha (Cerovsky, 1988). In September 1990 the first five national parks were designated, along with a proposal for six new Biosphere Resrves and 3 sites under a new designation of nature parks (Anon., 1990).

The 'post-revolution' government planned to set aside $10 \%$ of the nation's area for nature protection, utilising those lands previously used by the military and the former leadership. On 12 September 1990, five national parks, three nature parks, and 6 Biosphere Reserves were designated by the Volkskammer (GDR parliament). However it is the Bundesländer who will complete the designations (Anon 1990).

\section{ADDRESSES}

\section{$G D R$}

- Ministerium für Land-, Forst-und Nahrungsguterwirtschaft, Haupteilung Forstwirtschaft, Sektor Zagd/Landeskultur (Ministry of Agriculture, Forest Management and Food. Department of Forestry, Hunting and Land Cultivation Section), Köpenicker Allee 39-57, DDR-1157 Berlin.

\section{FRG}

- Bundesministerium für Umwelt, Naturschutz und Reaktorsicherheit, Abteilung Naturschutz, Umwelt und Gesundheit, Postfach 1206 29, 5300 Bonn 1.

(Each of the Länder has additional authorities for nature conservation) 


\section{REFERENCES}

Anon. (1990). National Parks for Germany, material for building a common European home. European Bulletin. Vol. 28, No. 107. Pp 10-11.

Ant, H. and Engelke, H. (1973). Die Naturschutzgebiete der Bundesrepublik Deutschland. Bundesanstalt für Vegetationskunde, Naturschutz und Landschaftspflege. Bonn-Bad Godesberg.

Cerovsky, J. (1986) (Ed.). Nature Conservation in the Socialist Countries of East - Europe. Administration of the Krkonose National Park, Vrchlabi.

Cerovsky, J. (1988) (Ed.). Nature Conservation in the Socialist Countries of East - Europe. East-Europe Committee, IUCN Commission on Education. Ministry of Culture of the Czech Socialist Republic, Praha.

Charlton, P. and Stiles, R. (1974). Landscape work in the countryside Landscape Design, 124. Pp 17-25. (unseen)

Davis, S. D., Droop, S. J. M., Gregerson, P., Henson, L., Leon, C. J., Lamlein Villa-Lobos, J., Synge, H. and Zantovska, J. (1986). Plants in Danger. what do we know? Threatened Plants Unit. IUCN, Gland, Switzerland, and Cambridge, UK. 461 pp.

Ertz, W. (1979). Katalog der Naturschutzgebiete in der Bundesrepublik Deutschland. Institut für Naturschutz und Tierökölogie der Bundesforschungsanstalt für Naturschutz und Landschaftspflege. Bonn.

Haarmann, K. and Pretscher, P. (1976). Die Feuchtgebiete IntemationalerBedeutung in der Bundesrepublik Deutschland. Kilda-Verlag, Greven. (unseen)

Holzner, J. (1986). Nature Conservation in the Federal Republic of Germany. Ecos. 7(4). Pp 13-18.

Kube, G. (1983). Interpretation in Germany's visitor centres. Parks, 8 (3). Pp 5-7. (unseen) Steinberg, K-H. (1990). Country address. GDR Minister for the Environment,Nature Conservation, Energy and Nuclear Safety. Action for a Common Future conference, Bergen, Norway, May 14-16, 1990.

Sword, K. (1990). (Ed.). The Times guide to Eastem Europe: the changing face of the Warsaw Pact. Times Books, London, United Kingdom. 270 pp.

Weinitschke, H. et al. (1980). Handbuch der Naturschutzgebiete der DDR (Handbook of Natural Protected Areas of GDR) (in German) 5 volumes. Urania Verlag, Leipzig-JenaBerlin. 2nd revised ed. 1980-1985. (unseen)

Weinitschke, H. (1982). Naturschutz gestem, heute, morgen. (Nature Conservation Yesterday, Today, Tomorrow) (in German) Urania Verlag, Leipzig-Jena Berlin. 104 pp. (unseen)

Weinitschke, H. (1986). Landnutzung und Naturschutz. (Land Use and Nature Conservation) (in German). VEB Gustav Fischer Verlag, Jena. 400 pp. (unseen) WWF-Titel. (1986). Naturschutzgebiete. WWF Joumal 2/86. Pp 5-12. (unseen) 


\section{SPECIAL NOTES}

It is not often that a country dissolves peaceably to become part of another state. However, in the case of the German Democratic Republic exactly this has happened. At midnight on the 3 October 1990 the two Germanies, divided since the Second World War, unified. Previous to this date monetary union had occurred and, of direct relevance to protected areas, legal precedence rested with the laws of the Federal Republic. It is yet to be seen how this legal union will affect the protected area system of these Eastern Länder, and what protection the previous legislation will give until rationalization of the new system. Due to the uncertainties inherant in the unification process both sets of legislation have been included, marking the historical and future growth in area protection.

DATE December 1986; reviewed January 1989; reviewed October 1990 


\section{COUNTRY: The Republic of Hungary}

AREA $93,032 \mathrm{~km}^{2}$

POPULATION $10,600,000$ (mid-1989 estimate) Natural increase $-0.2 \%$

GNP US\$2,240 per capita

\section{POLICY AND LEGISLATION}

The first legal measure on environmental management and protection was the Hungarian Forest Act which came into force in 1879 (then part of the Austro-Hungarian Empire). The Forests and Nature Conservation Act (Act IV/1935) was the first comprehensive act on nature conservation and laid the foundation for the preservation of scientifically valuable areas, wildlife communities, natural features and species. The 1935 Act was subsequently updated after World War II due to fundamental changes in the social and economic conditions and increasing awareness of nature conservation. The most important of these steps for improving nature protection was an ordinance adopted in Law, decree No. 18/ 1961 (updated in 1971). The Nature Conservation Act (1961) made provisions for a national supreme body for the management of nature conservation, this role is currently filled by the Ministry for Environment and Regional Development (Kömyezelvédelmi Ministerium). In 1972 a special governmental decree was enacted which enabled the establishment of national parks, with the first created at Hortobagy in 1973. The increased need for stronger enforcement and nature conservation control led to the Environmental Act II - an Act on the Protection of Human Environment, which was endorsed by Parliament in 1976. It was the first legislative act to provide the comprehensive protection for the whole range of the environment, synthesising all earlier legislation.

Nature conservation legislation was based on the Bill No. IV of 1982 and the Cabinet Decree No. 8/1982 on Conservation of Nature. These were introduced by the National Authority for Nature Conservation and they supercede all former acts on nature conservation. The basic objectives included: the assessment of natural assets and the declaration of protected areas; the determination of methods for maintaining areas under protection (balancing nature conservation operations with economic activities); acquiring ownership rights for protected areas, most notably those sites endangered by economic activities, and the protection and management of nature reserves. 
Protected Areas appear to be designated at the national or local level, according to their degree of importance. Those of national (and in some cases international) importance are National Parks, Landscape Protection Areas and Nature Conservation Areas. In addition, caves form a special category and all caves are under national protection. Sites of local importance are placed in two cat egories: County Nature Protection Areas and Natural Monuments. For certain special biotopes of some rare species, areas of intensive protection are defined within protected areas. They are only used for scientific research and are closed to the public ( 92 caves also receive this special protection) (Szilassy, 1989).

Definitions of the national protected areas are as follows:

Nemzeti Park (National parks) are large areas of land essentially of an unchanged natural state, where the landscape, fauna, flora or geological formations are of outstanding national importance. These areas are of value for public education and recreation. Zonation ensures that strictly protected areas exist where nature conservation is the prime management objective.

Tajvedelmi Korzetek (Landscape Protection Areas) are large areas of special scenic value that are protected to safeguard and maintain nature conservation values as well as landscape features. Protection of these areas extends to natural landscapes, regions and objects whose preservation and maintenance is of importance for science, culture or other public interest.

Termes Zetvedelmi Terulet (Nature Conervation Areas) established to preserve and maintain small areas of importance for nature conservation. They are divided into two categories: those of national significance and those of local importance, the latter being declared by county councils only (Tolgyesi, 1984). Under this category the Nature Conservation Act has guaranteed the protection of all caves (Fokozotttan Vedett Bartang-Protected Caves) since 1961.

Conservation legislation also provides for in situ protection of important fauna and flora resources. The safeguarding of habitats of the most valued protected species is one of the primary objectives for the designation of protected areas. More than $90 \%$ of the total number of vascular plant species, and $100 \%$ of the protected animal species benefit from in situ protected area designation (ECE Finland, 1986). Legislation states that it is forbidden to destroy, damage or change the character of natural landscapes, areas and objects declared protected. Utilisation of agricultural lands in declared protected areas can only be ensured in conformity with the category of protection, except in strictly protected areas where agricultural land may be withdrawn from use in the interest of nature conservation (Kallay et al, 1987). 


\section{INTERNATIONAL ACTIVITIES}

Bill No. IV of 1982 on Conservation of Nature stated that nature conservation should be incorporated within the framework of international conventions and protocols. Hungary acceeded to the Ramsar wetland convention on 11 April 1979; thirteen sites were listed in 1989. It was accepted as part of the World Heritage Convention in July 1985; no natural sites have yet been inscribed. Five sites covering 128,000 ha have so far been registered as biosphere reserves by Unesco (1982), two of these are bilateral: Aggtelek with Czechoslovakia and Ferto-to with Austria.

\section{ADMINISTRATION AND MANAGEMENT}

The first nature protection authority, the National Nature Preservation Council, was founded in 1939 under the auspices of the Ministry of Agriculture. It was replaced in 1961 by the National Authority for Nature Protection, an independent authority acting directly under the Cabinet. In 1977 this authority extended its power to cover co-ordination and supervision of nature and the protection of environment and it was renamed the National Authority for Environment Protection and Nature Conservation (Orszagos Komyezet es Termeszetvedelmi Hitaval, OKTH). Under the provisions of the 1982 Cabinet Decree, administrative tasks, supervision, co-ordination and control of nature conservation activities were the duties of the President of OKTH. On 1 January, 1988, the OKTH was merged with the National Office of Water Management to establish the Ministry for Environmental Protection and Water Management (KVM - Kömyezelvédelmi és Vizgazdalkodasi Ministerium). This was subsequently replaced by the Ministry of the Environment and Regional Development (Kömyezelvédelmi Ministerium).

The KVM had a network of twelve regional directorates, as well as four directorates for National Parks. The Ministry embodied 17 separate technical or operational units among which are those for air protection, water protection, river regulation and nature preservation. At the national level KVM had eight departments including the department of nature conservation, which was divided into four constituent parts including the division of landscape protection. The latter had seven inspectorates which actually carry out management. The National Parks are managed by their own directorates. Aspects of the environment still remain under the control of other senior authorities: the Ministry of Agriculture and Food supervises the conservation of soils and forests as well as the protection of landscape not declared on nature conservation grounds. The Ministry for construction and Town Development deals with the urban environment, and the Ministry for Industry and its Central Authority for Geology protects mineral resources. Through the network of regional directorates the KVM supervised and controlled nature conservation activities such as the organisation and promotion of scientific research and law enforcement in protected areas. 
At the local level tasks within the regional responsibility of the KVM were carried out jointly by its local organisations, the inspectorates for environment protection and nature conservation and the national park directorates. The inspectorates are responsible for the management of areas of national importance whilst the national park directorates manage their specific areas. They employ nature conservancy guards to safeguard and prevent damage of protected areas (National Authority for Environment Protection and Nature Conservation, 1983, 1984). County committees for environmental protection and nature conservation act as advisory and controlling bodies, their work includes maintenance of protected areas. They report to central authorities.

Although the democratic elections held in April 1990 have resulted in a reorganisation of the KVM, the new Ministry of the Environment and Regional Development will have a similar modus operandi.

Between 1976-1980 0.5 billion forints (out of a total environment budget of 41.2 billion forints) were spent on nature conservation and landscape protection (Sasvari, 1982; Cerovsky, 1988). The KVM spent approximately 400 million forints annually on environmental protection research in the Institutes of the Academy of sciences and other institutions of higher education (Szilassy, 1989).

Of the numerous non-governmental organisations, the traditional hunting, fishing and animal protection societies are particularly active in the field of conservation. The Hungarian Ornithological Society, founded in 1974 is the largest voluntary organisation, with about 10,000 members and the ownership of one protected area. There are various voluntary national park friendship circles (with members being drawn into park management), such as the Friends of Bukk National Park, which grew into the Environmental Protection Association of the County of Borsod. The Speleological Institute supervises the protection of Hungary's caves (IUCN, 1988).

\section{SYSTEMS REVIEWS}

The majority of Hungary is lowland, bissected by the Rivers Danube and Tisza. There are low mountains in the north, reaching a maximum altitude of $1015 \mathrm{~m}$. Protected areas include examples of the four main natural vegetation types: a) mountain bog on peat; b) mountain meadows, also containing important alpine flora; c) steppe or puszta; and d) broadleaved and coniferous woodland. Other protected habitats include lakes (Lake Balaton is the largest lake in central Europe and an important bird migration area), soda lakes, volcanic mountains and extensive cave systems. The climax vegetation of the Great Hungarian Plain was steppe-woodland, dominated by Quercus but most of this was removed during the sixteenth and seventeenth centurie and has been replaced by steppe-grassland (puszta), an alkaline and very saline grassland rich in annuals (Grimmett and Jones, 1989; 
Davis et al., 1986).

Hungary is densely populated with an agriculturally dominated economy. Forests still cover $17 \%$ of the land (increased from $12.4 \%$ in 1945), while meadows cover $5.4 \%$ and arable and grazing land covers $67.7 \%$ (Cerovsky, 1986; Grimmett and Jones, 1989).

The first protected area was the Forest of Debrecen, which was designated in 1939. By 1970 the total protected areas system covered only $15,000 \mathrm{ha}$. In less than ten years from 1970 the protected areas system was increased to exceed 400,000 ha. By the end of 1987 protected areas covered 550,000 ha, or approximately $5.9 \%$ of the country (Szilassy, 1989).

The puszta steppes are threatened by agricultural intensification, rice crop production and most recently by land use and ownership changes. Other major threats and problems include soil erosion, threats of floods and the proposed Gabcikova/Nagymaros Danube river barrrage system (GNRBS) which threatened to disrupt water levels along the Danube. Work on this project has been halted on the Hungarian side since May 1989. The Soviet Army has been accused of using some territory within national parks for firing ranges and ammunition dumps.

\section{ADDRESSES}

- Kömyezelvédelmi Ministerium (Ministry for the Environment and Regional Development), 1011 Budapest I., Fö u. 44-50. Levélcim: 1394 Budapest, Pf 351.

\section{REFERENCES}

Anon. (1983). Nature Conservation legislation in Hungary. NationalAuthority for Environment Protection and Nature Conservation, Budapest. 55 pp.

Borhidi, A and Janossy, D. (1984). Protected Plants and Animals in Hungary Ambio 13(2):106.

Cerovsky, J. (1986) (ed). Nature conservation in te socialist countries of East Europe. East Europe Committee, IUCN Commission on Education. Ministry of Culture of the Czechoslovak Socialist Republic, Prague.

Cerovsky, J. (1988). Nature Conservation in the Socialist Countries of East Europe. EastEurope Committee, IUCN Commission on Education. Ministry of Culture of the Czech Socialist Republic, Prague.

Davis, S. D., Droop, S. J. M., Gregerson, P., Henson, L., Leon, C. J., Lamlein Villa-Lobos, J., Synge, H. and Zantovska, J. (1986). Plants in Danger, what do we know? Threatened Plants Unit, IUCN-CMC, Kew, UK.

ECE Finland. (1986). Environment seminar 16/25-29 August 1986 . ENV/SEM 16/R1. 28pp. 
Glenny, M. (1988). Hungarian Greens with the Danube Blues. New Scientist 18 August. Pp 28-29.

Grimmet, R. and Jones, T. (1989). Important Bird Areas in Europe. International Council For Bird Preservation, Cambridge. $888 \mathrm{pp}$.

IUCN. (1987). Directory of wetlands of intemational importance. IUCN, Gland, Switzerland and Cambridge, UK. $460 \mathrm{pp}$.

IUCN. (1988). Environmental protection profile of Hungary. East European programme working document No. 3. 29 pp.

Kallay, G. et al. (1987). Saving the birds welcome to Hungary. Hungarian Ornithological Society, Visegrad, Hungary.

Kopasz, M. (n.d.). Environmental Education in Hungary's Universities andHigh Schools. Pp 31-33.

Laszio, E. (1984). The state of the environment in Hungary. Ambio 13(2). Pp 93-108.

National Authority for Environmental Protection and Nature Conservation. (1983). Nature conservation legislation in Hungary. National Authority for Environmental Protection and Nature Conservation/Department for International Relations, Budapest.

National Authority for Environmental Protection and Nature Conservation (1984). Management of national parks and other protected areas in Hungary. National Authority for Environmental Protection and Nature Conservation/Department for International Relations, Budapest.

Sasvari, A. (1982). Environmental protection in Hungary 1972-1982. Information from the National Authority for Environment Protection and Nature Conservation, Budapest.

Szilassy, Z. (1989). Hungary. Environmental Status Reports: 1988/9, Volume One. IUCN East European Programme, Cambridge. Pp 59-98.

Tolgyesi, I. (1984). Nature Conservation in Hungary: Presentation of a National Park. Parks 8(4).

DATE August 1988; reviewed October 1990 


\title{
COUNTRY: Republic of Poland
}

\author{
AREA $312,683 \mathrm{~km}^{2}$
}

POPULATION $38,200,000$

Natural Increase $0.6 \%$ per annum

GNP US\$ 1,974 per capita

\section{POLICY AND LEGISLATION}

The protection of specific natural objects is covered by a number of legislative acts starting with the decree of 1918, followed by the government ordinances of 1919 (Monitor Polski Nr. 208, poz. 2) and 1925, and culminating in the laws of 1934 (Dz.U.R.P.nr.31, poz. 274 Ustawa o ochronie przyrody) and 1949 (Nr. 25, poz. 180. Ustawa o ochronie przyrody), the last amended in 1972 (Amendment nr. 49 poz. 317) and in 1975 (Amendment nr. 17, poz. 94). The National Constitution of 1952 includes sections dealing with nature conservation (Article 8) and the protection and rational development of the natural environment (Article 12, Section 2). The Law on Nature Conservation of 7 April 1949 governs the organisation of nature conservation in general and introduced three protected area categories: national parks, nature reserves and natural monuments. This law governs the creation, administration and management of these three types of area. Two further types of protected area, landscape parks and areas of protected landscape, began to be created in the 1970s. The Law of 1980 concerning Protection and Management of the Environment (Ustawa $O$ ochronie i ksztaltowaniu srodowiska, Dz.U. Nr. 3, poz.6; zm.: DZ.U. z 1983 r., Nr.44, poz.201) regulates all problems connected with landscape protection. This is a general act, passed in January 1981, to regulate natural resource use in the national planning context and to control pollution levels and apply protection of the landscape in general terms.

In 1979 the State Council for Nature Conservation (Panstwowa Rada Ochrony Przyrody) (PROP) and the Department of Nature Protection in the former Ministry of Forestry prepared an outline draft of a new Nature Protection Law. This project, discussed over a number of years, dealt with conservation of nature separately to the Law on Conservation of the Environment. One of the aims of the project was to adjust the legislation to requirements of the International Union for Conservation of Nature (IUCN) and especially to the World Conservation Strategy. However, the project was discontinued and the new draft law was not passed. Attempts were also made to link the law of 1949 on nature protection with the law of 1980 on environmental conservation into one unified text 
and simultaneously to redraft the individual laws.

The new administration in 1990 is preparing a new framework law covering all aspects of environmental protection which is to be presented to Parliament by the end of the year. Sector laws will then be developed.

The four protected area classifications are:-

Parknarodowy (national park): the law on Nature Protection of 1934 (Article 9) defines these as 'especially beautiful landscape, rich in natural values ... for areas not less than $\mathbf{3 0 0}$ hectares'. Current legislation defines national parks as areas over 500 ha protected for their unique natural values, for their floral and faunal components and their overall landscape features. They were until 1989 created by decree of the Council of Ministers based on the recommendations of the Ministry for Conservation of the Environment and Natural Resources (Ministerstwo Ochrony Srodowiska; Zasobow Naturalnych) and expert advice from the State Council for Nature Conservation (PROP). In practice, areas proposed for conservation as national parks should be over $1,000 \mathrm{ha}$. They are zoned into strict protection areas and partial protection areas, the former excluding all human activity, the latter allowing active conservation management of selected elements. Additionally, several national parks have buffer zones designated around them. Each national park has its own administration, with a director in charge and between 15-30 supporting staff, with 1-2 individuals employed as scientific workers. Each national park is obliged to have detailed activity plans, such as a reserve management plan, a forest management plan, a scientific management plan and a spatial Management Plan (the latter is compulsory according to the 1949 law). Moreover, a scientific council, composed of specialists representing different branches of science, is appointed as an advisory body for each park. Within most national parks, natural museums containing specimens of nature typical for the protected area, used for educational purposes, are established.

Where any proposed developments are likely to damage designated areas, the state authorities are obliged to seek the advice of the State Council for Nature Conservation and to inform the Ministry for Conservation of the Environment and Natural Resources of such actions.

Rezenwat prayrody (nature reserve): these are areas of various sizes (mostly less than $100 \mathrm{ha}$ ) divided for management purposes into strict (fully protected) reserves and partial (partially protected) reserves. The former are used exclusively for research, the latter are subjected to controlled management activities. Most areas belong to the second group and many are mixed, with strict and partial protection of respective parts. Reserves are created under the 1949 law by decree of the Ministry for Conservation of the Environment and Natural Resources. Proposals for the creation of reserves are submitted to the Ministry by the Voivodship Conservator of Nature (Wojewodski Konservator Przyrody) who is responsible for the management of this type of protected area. They are classified into nine basic 
types according to the main object of protection: forest reserves, floristic reserves, steppe vegetation reserves, halophytic reserves, peatbog reserves, water reserves, faunal reserves, inanimate nature and landscape reserves. They are administered by the forestry authorities in the sub-forest district in which they occur while ten-year management plans are prepared by the Voivodship Conservator for Nature.

Park krajobrazowy (landscape park) also termed parki natury (nature park): this category combines nature conservation with the needs of recreation and tourism. They represent 'areas of exceptional natural values, ... with a predominance of natural landscape ... regarded as non-intervention zones for the development of industry and urban agglomerations and for large recreation centres'. These areas are created by regional authority (Voivodship People's Council) decrees under the 1980 law but only a few have their own administration. A spatial management plan is required which defines tourist carrying capacities, forestry and agricultural exploitation, industrial development and urban construction. A number of nature reserves and natural monuments can usually be found within landscape parks. Often a 'protective belt' is planned around them, mostly surrounded by a further area of protected landscape. A coordinating committee, appointed by the regional chief executive (voivoda), enforces the orders, restrictions and prohibitions and works within the limits of the spatial management plan for the region.

Obszarchronionego krajobrazu (area of protected landscape): these are also established under the 1980 Law by decision of regional authorities. They are more extensive territories than landscape parks and contain landscape features characteristic of a given region, often with cultural features as well, and are envisaged as major areas for recreation and tourism development. Economic activities (agriculture, forestry, industry) are not subject to serious limitations, but have to conform to certain standards. The areas are delimited in spatial management plans and included in regional voivodship plans. They are created and administered by the voivodship authorities, represented by the Conservat or of Nature.

Pomnik przyrody (natural monument) may also be included in protected areas. They are mostly single objects such as large trees, old alleys, cliffs, erratic blocks and rock outcrops. They are declared under the 1949 law by the voivodship authorities and protected by the voivodship Conservator of Nature on all natural monuments against any activity which would change their status. Special documentation on all natural monuments is provided by each region.

\section{INTERNATIONAL ACTIVITIES}

The World Heritage Convention was ratified in June 1976 with one natural site designated. The Convention on Wetlands of International Importance Especially as Waterfowl Habitat was acceded to on 22 November 1977 with one site listed. On 3 January 1984 four more sites 
were added. There are four biosphere reserves, designated in 1976.

\section{ADMINISTRATION AND MANAGEMENT}

The first administrative body dealing with nature conservation - the Temporary State Commission for Nature Protection - was created in Krakow in 1919 by Order of the Minister of Religious Persuasions and Public Enlightenment and was transformed in 1925 into the State Commission for Nature Protection. The Decrees of 1936 (Dz.U.R.P. nr. 94, poz. 660) and 1937 (Dz.U.R.P. nr. 27, poz. 195) created a Permanent Department within PROP and five regional Nature Protection Committees. The major activity prior to 1945 was the establishment of national parks and nature reserves. The Law on Nature Conservation of 1949 was followed by a Council of Ministers' Order of 1950 (Dz.U. nr. 13, poz. 127) creating the State Council for Nature Conservation (PROP) and in 1969 (Dz.U. nr.12, poz. 88) by the formation of Conservators of Nature offices in each of the 17 administrative regions (voivodships) of the country. Under Article 9 of the 1949 Law nature conservation became the responsibility of a Chief Conservator of Nature within the Ministry of Forestry and Timber Industry, but in the 1970s a separate Ministry, the Ministry of Administration, Regional Economy and Environmental Protection (Ministerstwo Administracji, Grospodarki Terenowej $i$ Ochrony Srodowiska) took over the overall control of environmental protection and spatial planning functions. On 12 November 1985 a new law (Dz.U. nr. 50, poz. 262) created the Ministry for Conservation of the Environment and Natural Resources (Ministerstwo Ochrony Srodowiska i Zasobow Naturalnych) which deals with all aspects of environmental protection (air, water, solid wastes, soils, water management, geology and nature conservation) and all matters governed by the Law on Nature Conservation of 7 April 1949, except the administration of national parks. The Chief Conservator for Nature was also a Vice-Minister whilst there was a separate Director in charge of the Ministry's Department of Nature Conservation and Soil Management (Departament Ochrony Przyrody i Powierzchni Ziemi). However, only the Ministry for Conservation of the Environment had executive control over national parks deciding overall principles of protection and management.

Administratively, the complete national park system was managed by the Ministry of Agriculture, Forestry and Food Economy (Ministerstwo Rolnictwa, Lesnictwa i Godpodaiki Zywnosciowej) and specifically by its Department of Forestry and National Parks (Departament Lesnictwa i Parkow Narodowych). This section employed specialists in nature conservation and maintained the central register for national parks, nature reserves and landscape parks. However, spatial planning was within the responsibility of the Ministry of Construction and Municipal Economy (Ministerstwo Budownictwa i Gospodarki Komunalnej).

In 1990 overall responsibility was taken over by the newly created Ministry of Environmental Protection, Natural Resources and Forestry (Ministerstwo Ochrony Srodowiska, 
Zasobow Naturalnych i Lesnictwa). This ministry is undergoing internal reorganisation and precise responsibilities are yet to be fixed.

According to the Law of 23 October 1987, the State Council for Nature Conservation and the State Council for Environmental Conservation are the official advisory bodies, the former on nature conservation matters, and the latter on environmental conservation aspects. The Minister for the Environment appoints members of both bodies and is their Chairman. The State Council for Nature Conservation gives advice and expert opinions on all projects concerning the creation of national parks, landscape parks and nature reserves and also presents its own initiatives. The State Council consists of a Secretariat and seven Permanent Commissions, including the Commission on National Parks and Nature Reserves, the Commission on the Protection of Inanimate Nature and the Commission on the Protection and Management of the Landscape. The Commission on National Parks and Nature Reserves cooperates closely with the councils of specific national parks, with the Voivodship Conservators of Nature and with the Academy of Science's Nature Protection Research Centre (Zaklad Ochrony Przyrody i Zasobow Naturalnych, PAN), with the Nature Conservation Research Centre of the Polish Academy of Sciences (Zaklad Ochrony Prayrody $i$ Zasabow Naturalnych PAN) and with the Forestry Research Institute (Instytut Badawczy Lesnictwa - Zaklad Ochrony Przyrody). The Commission is responsible for the preparation of documentation (or its review) prior to the creation of new national parks and nature reserves and for programmes of protected areas systems as well as research and management.

The 1949 Law envisaged wide social and community involvement in nature protection and resulted in the creation of the voluntary Citizen Nature Conservation Guards (Straz Ochrony Przyrody), which is composed of the Nature Conservation League (Liga Ochrony Przyrody) (founded in 1928 and now with 1,600,000 members), the Polish Tourist Society, the Polish Hunters Society, the Polish Anglers Society and the Alpine Club. Among the hundreds of emerging non-governmental organisations the Polish Ecological Club (Polski Klub Ekologiczny) was created in 1981 and with its regional sections provides independent advice on protected areas' creation and management.

\section{SYSTEMS REVIEWS}

The landscape is dominated by the northern European plain which takes up the majority of the country (with only $9 \%$ of the land over $300 \mathrm{~m}$ ) bordered to the north by the Baltic Sea and to the south by the Carpathian Mountains. There are lake districts in the north west and the north east (over 1,000 lakes covering $2 \%$ of the country) with some of Europe's most extensive lowland peatbogs ( 1.5 million ha) present in the east of the country.

The landscape is principally agricultural, with $30 \%$ forest cover. Natural elements of this 
forest contain Quercus spp., Tilia spp. and Carpinus betulus; Picea and Pinus occur in the mountains. There is about $25 \%$ natural and semi-natural vegetation cover.

Legal conservation of nature and landscape in Poland has a long tradition. Specific nature protection and hunting legislation dates back to the reign of the Piast and Jagiellon dynasties (14th centuries). The so-called "Wislice State", edited by King Kazimierz the Great in 1347, defined prohibitions of destructive activity in woodlands, such as pasturing of domestic animals in forests, cutting trees harbouring bees and making fire. The major document dealing with forest nature protection was the Warecki Statue (1420-1423), in which King Wladyslaw Jagiello forbade the felling of yews, prohibited making fire in forests and poaching large animals.

The first programme for the creation of a network of reserves was elaborated at the beginning of the 20th century and by 1918 there were 39 small nature reserves totalling 1,469 ha. This number increased to 180 covering 28,478 ha by 1937 . Simultaneously with the creation of nature reserves, proposals were made to establish national parks. The main attention was paid to the mountain regions such as Tatras, Pieniny, Babia Gora, Gory Swietokrzyskie and to Bialowieza Primeval Forest in the lowlands. The first proposal to create Tatra National Park was submitted in 1885, only 13 years after Yellowstone, but complicated property structure there meant that the first Polish national park was created not in Tatras but in Bialowieza Forest. At first it was a large reserve created in 1921 and transformed into Bialowieza National Park 11 years later (1932) on the 50th anniversary of Yellowstone. By 1936 five national parks had been created in Poland, Bialowieza, Pieniny, Babia Gora, Wielkopolski and Czarnohora (now in the USSR), totalling over 10,000 ha, but none was given legal recognition.

In 1988 the total area protected in national parks and nature reserves amounted to 252,791 ha, or $0.8 \%$ of the surface area of the country, while the joint area of all types of protected territory, including areas of protected landscape, reached the total of about $5,724,694$ ha, or $18.3 \%$ of the country. According to the development plan for nature conservation, the total area of national parks will amount to 230,000 ha by $1990(141,414$ ha in 1989) by the addition of five new parks and the extension of a few existing parks, while nature reserves should increase by c. 600 sites, giving a total area of $180,000 \mathrm{ha}(111,377 \mathrm{ha}$ in 1989). The total protected area is projected as being $8,734,500$ ha or $28 \%$ of the surface area of the country. In the 1980 s only two national parks were created (Gorce and Wigry), while one park was extended by the addition of a buffer zone. Only four had legally satisfied their spatial management plans, three parks were awaiting extension and six others were in the process of ratification. As of January 1989 there were 15 national parks $(141,414 \mathrm{ha}), 970$ nature reserves (111,377ha), 54 landscape parks $(1,992,753 \mathrm{ha})$ and 159 protected landscape areas $(3,479,150 \mathrm{ha})$.

The major threats to national parks are a combination of uncontrolled tourism, aerial 
pollution, water pollution and unsuitable forms of economic development. A survey in 1983 suggested that two-thirds of the surface area of Poland's forests is in a state of disaster and industrial pollution has directly damaged $654,000 \mathrm{ha}$ of woodland. The National Spatial Management Plan until the year 1996 identified 27 regions (11\% of the surface area of the country) as ecologically damaged, nine national parks and six landscape parks as severely threatened and 23 health resort areas as threatened. In 1982 the Academy of Sciences published a 'State of the Environment' report (nine volumes), and in 1985 four areas were declared 'ecological disaster' areas and 23 as of 'high ecological risk'. Also in 1982, the Polish Forest Society elaborated a report on the 'State of forests and their management in Poland'. This document discloses that in the post-war period (1954-1980) more than 610 million $\mathrm{m}^{3}$ of wood, about 115 million over the projected limit, were cut down. Each year's wood production averaged $123 \%$. A significant share in this production came from national parks and reserves. The number of tourists have reached an annual total of 9 million. There are proposals for national parks to be zoned to provide areas for recreation, communications and other uses.

\section{ADDRESSES}

Ministerstwo Ochrony Srodowiska, Zasobow Naturalnych i Lesnictwa Ul. Wawelska 52/54, 00-922 Warsaw. Tel: 25-41-41. Tlx: 817157 wodro. Fax: 253355.

Panstwowa Rada Ochrony Przyrody, Wawelska 52/54, 00-922 Warsaw.

Zaklad Ochrony Przyrody i Zasobow Naturalnych Ul Lubicz 46, 31-512 Krakow. Tel: 2151-44. Tlx:322414 PAN PL.

\section{REFERENCES}

Cerovsky, J. (1986). Nature Conservation in the Socialist Countries of East-Europe. EastEurope Committee, IUCN Commission on Education, Administration of the Krkonose (Giant Mountains) National Park. Vrchlabi.

Cerovsky, J. (1988). Nature Conservation in the Socialist Countries of East-Europe. EastEurope Committee, IUCN Commission on Education, Ministry of Culture of the Czech Socialist Republic, Prague.

Denisiuk, Z. (1989). Protected areas in Poland. 12 pp.

IUCN. (1971). United Nations List of National Parks and Equivalent Reserves. (2nd) Hayez, Brussels.

Karpowicz, Z.J. (1987). The Polish Park System. Unpublished PhD thesis. University of Birmingham.

DATE September 1987, reviewed January 1989, updated May 1989, reviewed Oct 1990 


\title{
COUNTRY: Romania
}

\author{
AREA $237,500 \mathrm{~km}^{2}$ \\ POPULATION \\ 23,077,000 (UN 1985) \\ Natural Increase $0.5 \%$ per annum \\ $23,200,000$ (1989 estimate)
}

GNP US\$ 6,453 per capita (Anon 1990)

\section{POLICY AND LEGISLATION}

The first Nature Protection Act came into force on 7 July 1930. A new act passed in October 1950 (Act No. 237) on the Protection of Natural Monuments was complemented by Order of Council No. 518 of 1954. In the same year an Environment Protection Law was introduced, to be replaced by the Environmental Law passed in 1973 (No. 9/1973). Section VI, Article 29 of this law specifies the official concept governing a national park, the legislative framework and the procedure for creating such protected areas (Oarcea, 1984).

Forests are protected by the 1954 Forest Code and the subsequent 1962 Forest Code. In 1976, a national programme to protect and develop forest resources was initiated. Full protection is afforded to about $14 \%$ of forest cover (Pop et al., 1965) with a further $36 \%$ of forests classified as 'protective forest' where restrictions on forest operations, in some cases, results in complete protection. Five categories are defined: soil conservation and the reduction of avalanches, the protection of water supplies, the use of forests for recreation, for landscape protection specifically surrounding urban, industrial, tourist and health zones and as scientific research areas protecting rare fauna, geological and speleogical formations (Kirby and Heap 1984). The scientific research category was one established (until 1990) by either the Commission for the Protection of Natural Monuments of the Academy of Sciences or by the Ministry of Forest Economy, whilst areas under the soil conservation category (on slopes over $35^{\circ}$ ) were subject to total protection, operated jointly by the Commission and the Ministry.

Protected areas are classified into national park, nature park and nature reserve categories:

Rezervatii naturale (nature reserves) are divided into seven categories classified as mixed forest, botanical, zoological, geological, morphological, palaeaontological and spele- 


\section{Romania}

ological (Alexandrowicz, 1982). Ecosystems within nature reserves are under complete protection, and access is subject to special authorisation with tourists allowed to enter by special permit only (IUCN, 1971). Several have strictly defined protected areas or scientific research zones where house construction and quarrying is not allowed without authorisation (IUCN, 1971; Cerovsky, 1988).

Parcul naturala (nature parks) would protect large areas of the landscape. These are still at a planning stage and lacking legal guidelines.

Parcul national (national park) category has three basic functions: scientific, socio-educational and economic (Oarcea, 1984) and is divided into two sectors: a strictly protected zone and a protected zone. The strictly protected zone has complete protection with no permanent residence allowed, no pasturing but some biological control of insect pests is permitted. In the protected zone hunting is forbidden but fishing is allowed in some lakes, subject to fish stocks. Grazing of domestic stock is also permitted in July and August, and tourism is encouraged (Retezat national park).

\section{INTERNATIONAL ACTIVITIES}

Romania has been involved in Unesco's MAB programme (three areas were declared as a biosphere reserves in 1979, with a fourth site (Danube Delta) added in 1990), and was accepted to the World Heritage Convention on 16 May 1990 (no natural sites as yet listed).

\section{ADMINISTRATION AND MANAGEMENT}

In 1930, as a consequence of the Nature Protection Act, a Commission for Natural Monuments was established within the Ministry of Agriculture and Landed Estates. In 1950, a new Commission, Comisia pentru Ocrotirea Monumentelor Naturii Academii Republici Socialiste Romania (Commission for Natural Monuments of the Romanian Academy of Sciences) was created, consisting of a Chairman and eight members. The Commission acted as the main coordinator of research and nature conservation activities, with field projects and monitoring carried out by university biology and geography departments and by other academic institutes. A Scientific Research Base was established at Timisoara.

The supreme authority for environmental matters was the Consiliul National pentru Conservarea Mediului (National Council for Environment Protection) at the Council of Ministers (Cerovsky, 1986) which came under the Consiliul National pentru Stïnta si Tehnologie (National Council for Science and Technology). Another influential body was the Academia de Stiinte Agricole si Silvice (Academy of Agricultural and Forestry Sciences).

The nature conservation administration was organised on a regional basis with the three 
constituent territories of Transylvania, Moldavia and Walachia divided into 40 regions, Bucharest making 41. The Commission parallels this structure with sub-commissions for the Protection of Natural Monuments in Cluj-Napoca (set up in 1933), in Craiova (set up in 1936) and in Iasi (set up in 1938). At the lower administrative level each region had a local committee (responsible to the People's Council), in charge of wildlife conservation with representatives from forestry, hunting, fishing, agriculture and education (Cerovsky, 1986; Kirby and Heap, 1984).

The Commission had a staff of specialists (biologists, forest engineers) and administrative personnel. Its main responsibility is to designate new nature reserves (for which proposals are prepared) and to administer reserve areas (including national parks) although it carries out only limited management work. It has the right to intervene in all questions concerning road construction, siting of industrial developments, tourist camps and any activity which is liable to deteriorate the reserves or degrade the landscape. The regional offices have staffs of approximately 200 .

Each nature reserve has at least one warden, called a guardian, who regulates access and controls grazing rights as well as preventing illegal entry, fishing and hunting. The reserve guardian may be an employee of the national forest service and as such is often responsible for economic forest land in addition to his duties on the reserve (Kirby and Heap, 1984).

Since the summer of 1990, a new Ministry of Water Management, Forests and the Environment has been set up which operates through the existing 41 regional offices. National parks come under the administration of the Commission, a function soon to be given to the Ministry's Department of the Environment (A. Vadineau, pers comm. 1990).

The Society for Tourism and Nature Protection was created in 1920 followed in 1922 by another voluntary body, the Mountain Brotherhood (Cerovsky, 1988). More recently formed groups include the Ecological Movement of Romania (MER - Miscarea Ecologista Din Romana), the Romanian Ecological Society (Societatea Ornithologica Romana) and the Ecological-Cultural Party. Each have a general interest in protected areas (Fisher 1990).

\section{SYSTEMS REVIEWS}

The country is divisible into lowlands less than $200 \mathrm{~m}(33 \%)$, hills and highlands between $200 \mathrm{~m}$ and $300 \mathrm{~m}(36 \%)$ and mountains averaging at $800 \mathrm{~m}(31 \%)$. Forests cover between $20 \%$ and $27 \%$ (Kirby and Heap, 1984; Cerovsky, 1986). There are three main vegetation zones present: steppe in the south-east (largely under agriculture), forest-steppe in the centre of the country and montane forests in the Carpathians (Davis et al. 1986).

Proposals for the protection of the landscape and natural monuments date back to 1907. 
In the 1980's the Commission for Protection of Natural Monuments, in collaboration with the General State Forest Management Inspectorate, constructed a concept for the elaboration of a national park system consisting of at least 12 parks. The study dealt with establishment criteria, organisation and management and preparatory studies covering four new national parks.

In the early 1980's there were between 300 and 310 nature reserves covering $0.5 \%$ of the country (Alexandrowicz, 1982, Ionescu et al. 1985). By 1986 this had risen to 420 nature reserves and one national park (Cerovsky, 1986) covering 222,545ha (Boscaiu, 1985).

Up to the end of 1989, there was only one designated national park (parcul national) with a further 11 in preparation (Cerovsky, 1988). In 1990, these 11 national parks were created and one further national park, Dracea, has been proposed. Together those areas cover $664,057 \mathrm{ha}$ ( $2.79 \%$ of the country), which includes buffer and pre-park zones and also the proposed extensions to Retezat National Park.

The natural environment is presently threatened by a combination of factors such as industrial pollution, intensification of agriculture and tourism. For example, the Rosca-Letea Biosphere Reserve has until recently been threatened by agricultural development plans. These have now been stopped but the affects from upstream pollution sources are still a threat.

\section{ADDRESSES}

Secretary of State, Department of the Environment, Ministry of Water Management,

Forests and the Environment, R-Bucharest-Artera Noüa N-S, Tronson 5-6, Sector 5, Bucharest. Telephone -316044. Telex - 10455 or 10435. Telefax - 316199 .

\section{REFERENCES}

Alexandrowicz, Z. (1982). Wielkoprzestrzenne obszary rezerwatowe Rumunii. Chronmy Przyrode Ojczysta. 38(6). Pp 134-137.

Anon. (1990). PC Globe Inc. Tempe, Arizona.

Boscaiu, N. (1985). Le dévéloppement d'un système de réserves pour la protection de la flore de Roumanie. In: Nedialkov, S. et al. (Eds.) Intermational Symposium 'Conservation of Natural Areas and the Genetic Material they Contain' - Project 8 on the Programme 'Man and the Biosphere' (MAB) of Unesco, 23-28.09.1985, Blagoevgrad, Bulgaria. Vol II, BAN, Sofia. Pp 171-178.

Cerovsky, J. (1986) (Ed.). Nature Conservation in the Socialist Countries of East-Europe. East-Europe Committee, IUCN Commission on Education, Administration of Krkonose 


\section{National Park, Vrchlubi.}

Cerovsky, J. (1988) (Ed.). Nature Conservation in the Socialist Countriesof East-Europe. East-Europe Committee, IUCN Commission on Education, Ministry of Culture of the Czech Socialist Republic, Praha.

Davis, S. D., Droop, S. J. M., Gregerson, P., Henson, L., Leon, C. J., Lamlein Villa-Lobos, J., Synge, H. and Zantovska, J. (1986). Plants in danger, what do we know? Threatened Plants Unit. IUCN, Gland, Switzerland, and Cambridge, UK. 461 pp.

Fisher, D. (1990). (unpublished). Developments within the environment movement. 1012 March 1990, 28 March-8 April 1990. Romania.

Horeau, C. and Cogran, I. (1981). Rezervatii naturale si monumenti ale naturii din judentul Vaslui (Nature reserves and natural monuments) (unseen).

Ionescu, M. and Condurateanu-Fesci, S. (1985). Parcuri si Rezervatii Naturale Pe Glob. Colectia Cristal, Bucuresti.

IUCN. (1971). United National List of National Parks and Equivalent Reserves. 2nd Ed. Hoyez, Brussels.

Kirby, K.J. and Heap, J.R. (1984). Forestry and Nature Conservation in Romania. Quarterly Joumal of Forestry 78(3). Pp 145-155.

Oarcea, Z. (1984). The evolution of the conception and the principles governing the creation and the setting up of the Retezat National Park. In: Pascu, S. et al. (Eds.) Recherches Ecologiques dans le Parc National de Rétézat. Travaux du Symposium du 13 avril 1984. Cluj-Napoca. Pp 27-31.

Pop, E. and Salageanu, N. (1965). Nature Reserves in Romania. Meridiane Publishing House, Bucharest.

Resmerita, I. (1983). Conservarea dinamica a naturii. Edit Stiinfica si encicilopedica Bucuresti. (Dynamic conservation of nature) (Unseen)

Seghedin, T.G. (1983). Rezervatiile naturale din Bucovina. Nature reserves in Bukovina. Edit Sport-turism. Bucuresti. (Unseen)

DATE December 1986; reviewed January 1989, reviewed October 1990. 


\title{
COUNTRY: Union of Soviet Socialist Republics
}

\author{
AREA $22,272,000 \mathrm{~km}^{2}$
}

POPULATION 286,717,000 (1989 estimate) Natural Increase 1.0\% per annum

GNP US\$ 8,865 per capita (Anon, 1990)

\section{POLICY AND LEGISLATION}

Several articles in the 1977 Constitution of the USSR reflect the growing prominence given to environmental protection. Article 18 makes it a primary duty of the State to protect and make scientific use of natural resources and to ensure air and water quality, whilst Article 67 obliges all Soviet citizens to protect nature and conserve its riches. It is augmented by the 1985 decree on the enforcement of nature conservation laws and the rational use of natural resources. A draft law to update and encompass all forms of environmental protection was prepared and submitted to the Council of Ministers in 1989 (Anon., 1988).

A long-term programme for environmental protection and rational use of natural resources of the USSR in 1991-1995 and until 2005 has been drafted. The programme is: to provide conditions beneficial for health, to preserve the biosphere (of relevance to protected areas), to utilise natural resources on a sustainable basis, to induce perestroika into ecological thinking and develop ecological awareness. According to preliminary calculations, its implementation will cost from 139 to 153 billion roubles in capital investments (Anon, 1989).

Relevant area protection laws appeared in Imperial Russia during the $1880 \mathrm{~s}$ in the form of hunting, land use and forestry regulations (Karpowicz, 1988), followed by the first conservation measures in 1909. Protected areas legislation appeared in 1921, in the form of a decree by the Council of People's Commissioners entitled 'Protection of Natural Monuments, Gardens and Parks' and signed by V.I. Lenin. In 1957 a series of acts addressing conservation were passed in the wake of the Conservation of Nature Act in Estonia. This was followed in 1968 by the Land Legislation laws of the USSR and union republics. In 1972 a decree was passed by the Central Committee of the Communist Party of the Soviet Union and the USSR Council of Ministers to strengthen nature conservation and improve the use of natural resources. This led to the current legislation which is based on the State regulations of 25 June 1980 (coming into force on 1 January 1981) and entitled The Law on 
Wildlife Protection and Use and The Law on Air Protection. These USSR and Soviet Republics acts on conservation and utilisation of fauna and on air conservation include regulations on protected natural areas and measures to ensure wildife protection (Articles 21-26) approved by the State Planning Commmittee and the State Science and Technological Committee of the USSR Council of Ministers (Kolbasov, 1981; Karpowicz, 1988). In 1985 the decree of the USSR Supreme Soviet covered conservation of nature law and rational use of natural resources.

The legislative status of State nature reserves is based on Article 21 (Section 6 "creating preserves and reserves") and Article 25 ("protection of animals in preserves, reserves and other protected areas") of the 1981 Law on Wildlife Protection and Use, following the former two acts of the Supreme Soviet, Principles of Land Legislation of the USSR and Union Republics (adopted on 13 December 1968) and Principles of Water Legislation of the USSR and Union Republics (adopted on 10 December 1970). In accordance with the Principles of Land Legislation, any activity disturbing natural ecosystems within reserves, or threatening the conservation of natural objects of special scientific or cultural value, is prohibited both in the territory of reserves and surrounding protected zones. The State regulations entitled The Status of State Zapovedniki enacted by the Council of Ministers of the USSR on 27 November 1951, together with the relevant regulations of the Republics, have been revised in the 1981 Act.

There are approximately 60 different categories of protected land which provide for nature conservation to varying extents. There are six main categories of nature conservation areas, represented both on the national and republic level. The principal category, and the most rigourously protected, is the state nature reserve or nature preserve, of which there are approximately 165 , covering 17.5 million ha in the 15 Soviet republics (less than $1 \%$ of the USSR).

Zapovedniks (State Nature Reserves) defined as typical or unique plots of natural land used by "scientific institutions...and studied for its natural complexes and established on land excluded from economic utilisation". Forbidden activities include building construction, any "economic activities", such as agriculture or industry and "unrestricted entry". As far as possible they are maintained in their natural condition unchanged by man. They exist both to protect threatened flora and fauna, and to serve as an outdoor laboratory for field study.

Most zapovedniki have a permanent scientific staff. Main management objectives include: (1) protection of wildlife and its habitats, including maintenance of entire ecosystems; (2) scientific research; and (3) strictly limited recreational activities, and, in some cases, controlled tourism. Surrounding each state nature reserve is an area semiprotected land which provides a buffer to the surrounding countryside. Existing economic activities are allowed to continue, providing they are not harmful (Knystautas, 1987). 
Natsional'nyi park (National parks) protected natural areas established in natural wildeness and altered landscapes (including arable land), although mainly on state forest property (Cerovsky, 1988). They are designated for recreation as well as nature protection and, as in the case of a protected lakeshore, differ from state nature reserves in that tourism is allowed (Braden, 1986). The legislation for national parks is complex. Sites are zoned into: areas in which economic activities are controlled; nature reserves containing the finest examples of original natural habitat, where economic activities and public entry is forbidden; nature sanctuaries (zakazniki) where tourists are allowed but economic activities are strictly prohibited; and peripheral buffer areas of economic activity, where habitation and sustainable levels of exploitation of natural resources (including fishing) are permitted (Knystautas, 1987).

Zakaznik (Nature sanctuaries or partial reserves) are natural areas partly withdrawn from economic utilisation because they contain outstanding landscapes, rare plants or breeding colonies of threatened species. Controlled hunting is sometimes allowed. Many zakazniki are only fully protected in certain seasons when all economic activities and entry is banned. Their status and administration varies in the different republics of the USSR. They are established to enable certain floral and faunal populations to recover within a specified time period. Exploitation is prohibited during this period, unless it does not interfere with management objectives (Braden, 1986; Knystautas, 1987).

Zapovedno-okhotnich'ye khozyastvo (National hunting reserve) are highly protected and provide vital refuges for wildlife.

Natsional'nyi pamyatnik (Nature monuments or national monuments) consist of limited areas surrounding isolated natural features such as geological sites or exceptionally old trees. Approximately $40 \%$ of these sites are of botanical interest (Braden, 1986).

Protected seashore areas, sea islands and sea shelves are established to protect the environment, conserve gene pools and provide for the restoration of resources, recreation and education (Borodin et al., 1984).

In addition, there are state forests and forest reserves established to protect watersheds, to provide windbelts and control erosion. Green zones and forest parks are usually protected green belts around cities and health resorts. They have limited nature conservation value and are usually managed cultural landscapes with a high recreation priority (Borodin et al., 1984).

\section{INTERNATIONAL ACTIVTTY}

In a Pravda article entitled "The Reality and Guarantee of a Safe World", Mikhail Gorbachov identified the need to develop a global strategy for environmental protection 
and rational use of natural resource activities. This official view supports the Soviet Union's international conservation cooperation (Anon, 1989).

In 1988 the USSR participated in 55 international conventions and agreements in the field of environmental protection. Amongst them several concern protected areas (Anon 1989). A network of wetlands of international importance has been established under the Ramsar Convention, which was ratified by the USSR on 11 October 1976. In 1990 there were 12 sites. A further 16 are proposed adding $8,000,000$ ha to the network. The USSR is also actively involved in developing a network of biosphere reserves under the Unesco MAB programme (in 1990 there were 19 sites). The USSR signed the World Heritage Convention on 12 October 1990 but no natural sites are as yet listed although Lake Baikal and Kronotskiy zapovednik on Kamchatka are provisionally under discussion. International cooperation between the USSR and the USA has extended to the twinning of reserves for comparative research and management purposes. An international peace park may be sited on the shores of the Bering Strait.

Multilateral cooperation between the members of the Warsaw Pact is implemented within the framework of the Permanent Commission of the Warsaw Pact on Cooperation in Environmental Protection, founded by a resolution of the Warsaw Pact session held in 1988. This commission reviews the most important conservation problems of the member nations (Anon, 1989). A transboundary park has been established with Finland, and others are proposed with Poland, Czechoslovakia, Romania, Mongolia and China.

Cooperation with Sweden has been implemented within the framework for a Joint Working Group on Environmental Protection under the Soviet-Swedish Intergovernmental Commission on Economic and Scientific and Technical Cooperation. Among the primary areas of cooperation is the conservation of ecological systems and individual flora and fauna species (Anon, 1989).

\section{ADMINISTRATION AND MANAGEMENT}

Until 1988 the supreme authority for broad and comprehensive environmental issues (executive and management roles in nature conservation) was the central government's Council of Ministers and its representatives within each republic. Administration was handled by national bodies such as the State Committee for Hydrometeorology and Natural Environmental Control (concerned with nature conservation, forestry and game management) and the USSR Agro-Industrial Trust (formerly USSR Ministry of Agriculture), with committees at republic level.

In January 1988 the administrative bureaucracy became streamlined and simplified by the creation of the USSR State Committee for Nature Conservation (Goskompriroda), 
which is now responsible for co-ordinating conservation activities throughout the whole of the USSR. Goskompriroda has offices at the Republic level, further divided into 200 oblast (district) level offices each with an average of 200 staff. Its main tasks include monitoring the use and conservation of natural resources, management of nature reserves, monitoring of hunting activities, registration of threatened fauna, production of the USSR red book and dissemination of information about the environment.

In 19854.4 million roubles were spent on national parks and 27.8 million roubles on the state nature reserve system by 28 different administrative bodies, employing over 1,000 specialists. In 1988 a budget of 10,000 million roubles was earmarked for use by the State for environmental protection, as compared with a total of 60,000 million roubles spent during the previous decade (Karpowicz, 1988).

On 1 January 1975 the then 106 state nature reserves (zapovedniki) were under the direct or indirect supervision of the Department of Nature Conservation and Game Management of the USSR Ministry of Agriculture. The majority of zapovedniki are managed by the departments or committees of nature conservation in the republics but some fall under the supervision of the USSR Academy of Sciences. By 1988 most zapovedniki had come under the administration of the Chief Administration for Nature Conservation, Nature Reserves, Forestry and Game Management (Glavpriroda). Final approval for the establishment of reserves was given by Gosplan, the State Planning Committee (Braden, 1986). Most zapovedniki have 5 to 20 scientific staff, additional research being undertaken by the Academy of Sciences, universities and other institutions (Braden, 1986). In the RSFSR, national hunting reserves are administered by Glavokhota, the Chief Administration for Hunting and Nature Reserves. Rangers are responsible for controlling poaching and hunting is limited to sustainable levels.

The oldest and the largest organisation for nature conservation in the USSR is the All Russian Society for Nature Conservation. Founded in 1924, it is reputed to be the largest in the world, with 38 million members active in local groups, collectives and state farms, factories, offices and schools. In all Soviet republics there are national nature conservation societies which work within the framework of the peace council of the USSR. Other societies include the USSR Geographical Society, USSR Theriological Society and the USSR Ornithological Society. The basis of nature conservation is taught both in schools and in universities and other institutions of higher education (Kaystautas, 1987). A union of environmental protection societies was set up in early 1989.

In the past even designated protected areas were not completely secure from short-term economic gain, and during the Stalinist era the reserve status of 88 zapovedniki was removed. Encroachment on protected areas persists. Problems include oil prospecting, livestock grazing, over-fishing, uncontrolled tourism, illegal building schemes and hunting by the privileged few (Braden, 1986; Karpowicz, 1988). The Dneprovsko-Teterevskoe 
Nature Hunting Reserve lies partly within zone A (total evacuation) of the Chernobyl reactor accident site.

\section{SYSTEMS REVIEWS}

The USSR is the world's largest country covering one sixth of the globe's land surface. For the most part it is lowland, with only $5 \%$ lying above $1500 \mathrm{~m}$.

There are four distinct vegetation zones: tundra, forest (broadleaf woodland and coniferous taiga), steppe and desert. The deserts and semi-deserts (Central Asia) fringing the southern borders give way to steppe and temperate grasslands which are replaced by a great zone of broadleaf woodland and conifer taiga forest stretching for more than $11,250 \mathrm{~km}$ east-west, and by treeless cold desert and tundra along the northern coasts. Forests now cover 7.47 million $\mathrm{km}^{2}$ ( $33 \%$ of the USSR) with vast areas of forest remaining virgin in the far north, parts of Siberia and in the high mountains (Davis et al. 1986).

Protected territories play an important role in the conservation of rare species of mammals. They contain $39 \%$ of the amphibian mammal species, $55 \%$ of the bird species, $56 \%$ of the fish species, $68 \%$ of the reptile species and $90 \%$ of the amphibians listed in the Red Book of the USSR. Protected areas have been virtually the only means for the conservation of a number of species, such as Amur tiger, kulan, goral, Bukhara deer and spotted deer (Anon, 1989).

\section{ADDRESSES}

- USSR Goskompriroda, Nezhdanna Street 11, Moscow K-9, 103009. Telex 411258 zerno su. Tel. 01070954230311.

\section{REFERENCES}

Anon. (1988). Resolution on the formation of USSR State Committee for the Protection of Nature. Pravda, 17 January 1988.

Anon. (1989). Report on the state of the environment in the USSR, 1988. USSR State Committee for the Protection of Nature. Moscow 1989. $151 \mathrm{pp}$.

Anon. (1990). PC Globe Inc. Tempe, Arizona.

Borodin, A.M., Isakov, Y. and Krinitsky, V.V. (1984). The system of natural protected areas in the USSR: biosphere reserves as part of this system. In Conservation, Science and Society. Unesco, Paris. Pp 221-228.

Braden, K. (1986). Wildlife reserves in the USSR. Oryx 20. Pp 165-169.

Cerovsky, J. (1988). Nature conservation in the socialist countries of East Europe. East- 


\section{USSR}

Europe Committee, IUCN Commision on Education/Ministry of Culture of the Czech Socialist Republic, Prague.

Davis, S. D., Droop, S. J. M., Gregerson, P., Henson, L., Leon, C. J., Lamlein Villa-Lobos, J., Synge, H. and Zantovska, J. (1986). Plants in Danger, what do we know? Threatened Plants Unit. IUCN, Gland, Switzerland and Cambridge, UK. 461 pp.

Karpowicz, Z.J. (1988). Conservation and environment protection. In M.J. Berry (Ed.). Science and technology in the USSR. Longmans, London. Pp 361-379.

Kolbasov, O.S. (1981). Two new environmental laws. Environmental Policy and Law 7. Pp 79-100.

Knystautas, A. (1987). The natural history of the USSR. Century, London. 224 pp.

DATE December 1984, reviewed September 1988, reviewed October 1990 


\section{COUNTRY: Socialist Federal Republic of Yugoslavia}

AREA $255,803^{\circ}$

POPULATION $23,700,000(1989) \quad$ Natural Increase $0.6 \%$ per annum

GNP US\$ 2,480 per capita (1987)

\section{POLICY AND LEGISLATION}

Although environmental protection was written into the Federal Constitution (Ustav Socialisticka Federativne Republike Jugoslavije) of 21 February 1974 it was only recently incorporated into federal development policy as the 'Development policy in 1990 in the SFRY', Section 6.2. 'Environmental protection and promotion policies', Belgrade, December 15,1989 . Within the federal legislative framework, each republic and autonomous province enacts specific legislation concerning the protection of the environment and protected areas (Singleton, 1985; IUCN, 1987).

One of the earliest legal measures for nature conservation, the Hunting Act of 1893, was introduced when the country was under the control of the Austro-Hungarian Empire. Among the first laws adopted in 1945 was the law on the Protection of Cultural Heritage and Conservation of Natural Rarities.

The protected area legislation varies from one republic to another, as does the legislation covering the range of activities that can be carried out within protected areas (forestry, hunting, fishing and certain agricultural works). By 1985 there were no specific laws on the creation of marine protected areas. However, general texts on conservation allowed for the establishment of such sites (Singleton, 1985).

The most important types of protected natural areas have been classified into the following groups:

Nacionalni park or narodni park (national parks) constitute the largest natural zones of outstanding natural values. The first national parks were proclaimed in 1928 by the royal government which designated several areas in Croatia. Park management varies between republics, many sites being internationally recognised as national parks but others are essentially protected landscapes.

Regionalni park prinode, krajinski park, regionalni park,(regional natural parks or nature 
parks) constitute large areas of specific natural value and are of importance as landscape.

Rezervat prirode, strogi, naravni rezervat (natural reserves or nature reserves) are small in size. They are established to protect specific natural elements or species.

Spomenik prirode, naravni spomenik (Natural monuments) are outstanding geological or animate features protected for their rarity or specific properties.

Zasticeno rekreaciono podrucje (Recreational zones) are large areas such as sea coasts, lake shores, river banks, mountain resorts or natural features which are protected specifically for recreation and sports activities.

Ostala zasticena podrucja prirode (OZPP) or Karakteristicni pejsazi (Sanctuaries of landscape or recreational importance) are sites established largely for recreational importance, cultural heritage and characteristic landscape values are of extensive interest to tourism.

Memonijalni spomenik (Memorial monuments) are small natural zones established to protect historic features such as important battlegrounds.

Spomenik oblikovane prirode or hortikulturni spomenik (Ornate natural monuments or horticultural gardens) are notable landscape gardens.

\section{Bosnia and Herzegovina}

Natural reserve designation was enacted by a decision of the Institute for Protection of Cultural and Natural Monuments and Natural Rarities No. 683/54, strict reserves being set up by a decision of the National Institute for the Protection of Historic Monuments and Natural Beauty of 3 June 1964. Law No. 5, passed on 13 January 1972, resulted in the Executive Committee designation of Sutjeska National Park (IUCN, 1971; Baccar, 1977; Mestrovic, 1983).

\section{Croatia}

Parks are designated by laws specific to each site. For instance, whilst Mljet National Fark was designated under the Mljet National Park law published in 'Narodne novine' No. 49/ 60, 7 XII 1960, nature reserves in Croatia are declared under a decree for the Protection of Natural Rarity No. 221/48 and by proposals of the People's National Liberation Committee No. 05-5056/1 of 1961 (MAB, 1979). All activities in the nature reserves of Croatia are restricted by regional by-laws (Singleton, 1985). 


\section{Macedonia}

Each national park is designated under site specific laws. Only regional parks may be establised by region-wide legislation.

\section{Montenegro}

Protected areas are established by enactment of the conservation law of 6 August 1952. Plitvice National Park was established by the general act of 1954 . Kotor World Heritage Park, an example of the legal complexities of site designation, was enacted by the decision of three organisations: the Republic Institute for Protection of Nature of the Socialist Republic of Montenegro (under general decree No. 7/1968), Republic Institute for Protection of Cultural Monuments of the S.R. Montenegro and the Town Assembly of Kotor (declaration of 14 June 1979).

\section{Serbia}

This includes the incorporated provinces of Kosovo and Vojvodina. This republic follows the example of all others by designating areas under its own legislation.

\section{Slovenia}

National parks are created by special decree under the National Parks Law (Uradni List No. 6 of 1959).

\section{INTERNATIONAL ACTIVITIES}

The World Heritage Convention was ratified on 26 May 1975, with three natural sites inscribed by 1990 (one in 1979, one in 1980 and one in 1986). Yugoslavia became party to the Convention on Wetlands of International Importance on 28 March 1977, with two sites listed, and was one of the participating states in the Barcelona Convention (adopted in 1975). Two biosphere reserves were established between 1976 and 1977.

The network of biosphere reserves are linked in with WHO programmes in a joint effort to establish Environmental Specimen Banks (MAB, 1979). 


\section{ADMINISTRATION AND MANAGEMENT}

Environmental administration is in the form of a decentralised public authority structure in each republic (Bosnia and Herzegovina, Croatia, Macedonia, Montenegro, Serbia and Slovenia). The republics each have the power to set up a council for the protection of the environment which is charged with the responsibility of coordinating the activities of the various environmental agencies. The councils are federated together in the Jugoslavenski Savez za Zastitu i Unapredivante Covekove Sredine (SAVEZ), which advises on conservation matters (Singleton, 1985). An institute for nature protection exists in each of the six republics (IUCN, 1987). The institutes are staffed by biologists, geographers and lawyers, with a director who maybe either a civil engineer or a forester (Godiel, 1981; Singleton, 1985). By law each national park must have its own administration, professional staff and funds for effective protection (Godiel, 1981). Differences in administration and management arise between republics:

In Bosnia and Herzegovina the national parks have their own authorities whilst the nature reserves are administered by "Experimental Farms" belonging to the Ministry of Agricultural Economy.

In Croatia most of the national parks are administered by the cultural section of the Secretariat for National Education, Culture and Physical Education with each park having its own administrative committee, usually its own administrative office and a special management plan. In the case of the Lokrum and Krka reserves, the town assemblies are responsible for management under jurisdiction from the urban plan (IUCN, 1971).

In Macedonia the Depart ment of Agriculture and Silviculture has overall responsibility with each park having its own governing authority (IUCN, 1971; Singleton, 1985).

In Montenegro, some national parks such as Biogradska Gora have a special controlling body while others, including Durmitor and Lovcen, have administrative responsibility vested in the Nature Protection Institute of the Republic or in the Republic Secretariat for Education, Culture and Science. The management is carried out by a local self-management community who elaborate the plans (Singlet on, 1985). Responsibility for the management of Kotor World Heritage Site lies with the Town Assembly of Kotor, the Republic Institute for Protection of Cultural Monuments and the Republic Institute for Protection of Nature.

In Serbia the Republicki zavod za zastitu prirode manages nature conservation. The two incorporated provinces of Vojvodina and Kosovo also have nature conservancy authorities.

In Slovenia, Triglav National Park is administered by a special commission attached to the Assembly of Radovljica Commune whilst reserves are dealt with by the Forestry Service.

Non-governmental organisations in Yugoslavia tend to be regional. Ecological parties 
are being formed in some republics but these vary greatly in their influence. In Slovenia the Green Party is a major political force (Fisher, 1990).

\section{SYSTEMS REVIEWS}

Geographically in the centre of the Balkan peninsula, Yugoslavia has a great diversity of habitats, being under the influence of Mediterranean, alpine and lowland Pannonian climates of central Europe. Deciduous oakwoods cover the karstlands of the far north and the far south between 200 and $700 \mathrm{~m}$. Oaks Quercus spp. dominate at these altitudes, but are replaced by beech Fagus spp. at higher altitudes. Many of these forests are ancient and relatively undisturbed. In the central mountains, coniferous forest is dominant, with riverine forests of alder Alnus spp., willow Salix spp. and ash Fraxinus spp. at lower levels. The higher mountain massifs are well represented by relatively undisturbed alpine communities with many endemic plants. Coastal maquis is still widespread, with some patchy forest along the Croatian coast. The northern Pannonian plain is mostly agricultural, but with some relicts of steppe flora on saline soils (Davis et al. 1986).

A relatively low population density has ensured the survival of a number of important ecosystems, notably forest and alpine systems. In contrast the majority of the larger wetland sites have been drained and put under cultivation or pasture since the end of World War Two. In several of the wetlands that survive, suitable habitats for breeding waterfowl are seriously degraded or polluted (Duffey, 1982; IUCN, 1987; Singleton, 1987; Institute for Nature Conservation of the SR of Serbia, 1988).

The first major inventory of protected areas (Inventory of Natural Regions and Natural Monuments), undertaken in 1976, estimated such areas to cover $2.2 \%$ of the country. This figure had risen considerably by the time a second inventory was undertaken in 1987. For example, the number of protected natural regions and monuments has increased from 1,008 in 1976 to 1,313 in 1987. Designated national parks had risen from 16 to 22 by 1987 , with a total area of 524,784 ha (Institute for Nature Conservation of the SR of Serbia, 1988).

Some of the problems affecting protected areas include the conflict of interests between tourism, water and air pollution, economic development and conservation. Many of the park authorities have insufficient funds and have to rely on financial assistance from tourism, forestry, sporting and recreational activities. Sites which are near industrial complexes have also suffered from a lack of concern for environmental issues following rapid industrial expansion in the early 1950's (Duffey, 1982; Singleton, 1985; IUCN, 1987). 


\section{ADDRESSES}

\section{Federal}

- Republicki zavod za zastitu prirode SR Srbije, (Nature Conservancy), Treci Bulevar 106, 11070 Novi Beograd, Serbia. Tel: 142-281; 142-165.

\section{Republic}

- Zavod za zastitu spomenika kulkure prirodnih znamenitosti i rijetkosti SR Bosne I Hercegovine, (Office for the protection of cultural monument, Department of Nature Conservation), Obalu 27. jula 11-a, 71000 Sarajevo, Bosnia and Herzegovina. Tel: 071/ 653-555

- Republicki zavod za zastitu prirode SR Hravtske, (Nature Conservancy), Ilica br. 44, 41000 Zagreb, Croatia. Tel: 041/432-022

- Republicki zavod za zastitu na prirodnite retkosti SR Makedonije, (Nature Conservancy), Rudera Boskovica bb, Karpus II, 91000 Skoplje, Macedonia. Tel: 091/251-133

- Republicki zavod za zastitu prirode SR Crne Gore, (Nature Conservancy), Trg., Nikole Kovacevica br. 7, 81000 Titograd, Montenegro. Tel: 081/22-992

- Pokrajinski zavod za zastitu prirode SAP Vojvodine, (Nature Conservancy), Petrovaradinska tvrdarva, 21000 Novi Sad/Petrovasadin tvrdjava, Vojvodina, Serbia. Tel: 021/ $432-200$

- Pokrajinski zavod zastitu prirode SAP Kosovo, (Nature Conservancy), Lenjinova br. 18, 38000 Pristina, Kosovo, Serbia. Tel: 038/27-027; 27-026

- Zavod SR Slovenije za varstvo naravne in Kulturne Dedicene, (Institute for the protection of monuments and the department of nature conservation), Plecnikov trg.2, 61000 Ljubljana, Slovenia. Tel: 213-083

\section{REFERENCES}

Baccar, H. (1977). A survey of existing and potential marine parks and reserves in the Mediteranean region. IUCN/UNEY.

COE. (1987). Yugoslavia: New structures. In Naturopa newsletter. No 86-12.p4. (unseen) Davis, S. D., Droop, S. J. M., Gregerson, P., Henson, L., Leon, S. J., Villa-Lobos, J. L., Synge, H. and Zantovska, J. (1986). Plants in Danger, what do we know? IUCN, Gland, Switzerland and Cambridge, U.K. 461 pp.

Duffey, E. (1982). National Parks and Reserves of Westem Europe. Macdonald. Macdonald and Company, London.

Fisher, D. (1990). Environmental politics in Yugoslavia. In Environmental Policy Review 
the Soviet Union and Eastem Europe, vol. 4, No. 2, July.

Godiel, L. (1981). The protection of rare plants in nature reserves and national parks in

Yugoslavia. In: Synge, H. (Ed) The Biological Aspects of Rare Plant Conservation. John Wiley and Sons Ltd.

Gryn, Amroes, P. (1980). Preliminary Annotated List of Existing andPotentially Mediterranean Protected Areas. UNEP/IUCN report. UNEP/IG 20/INF 5. (unseen)

Institute for Nature Conservation of the SR of Serbia. (1988). Report of Yugoslavia. East European Task Force Meeting, Krakow, Poland, October 1988. Institute for Nature Conservation of the SR of Serbia for IUCN - East European Programme, Gland, Switzerland.

IUCN. (1971). United Nations List of National Parks and Equivalent Reserves. 2nd Ed. Hayez, Brussels.

IUCN. (1985). 1985 United Nations List of National Parks and Protected Areas. IUCN, Gland, Switzerland and Cambridge, UK.

IUCN. (1987). Directory of Wetlands of Intemational Importance. IUCN, Gland, Switzerland and Cambridge, UK.

MAB. (1977). Workshop on biosphere reserves in the Mediterranean region: Development of a conceptual basis and a plan for the establishment of a regional network. MAB report series No. 45 Side, 6-11 June 1977. Final Report, Unesco 1979.

Mestrovic, S. (1983). Nature Conservation in Yugoslavia. Nature and NationalParks 21. Pp 27-28.

Movcan, J. (1982). National Park Development and its Economics: Experience from Plitvice National Park, Yugoslavia. In: McNeely, J.A. and Miller, K.R. (Eds) National Parks, Conservation, and Development. The Role of Protected Areas in Sustaining Society. Smithsonian Institution Press, Washington, DC. (unseen)

OECD. (1986) Environmental Policies in Yugoslavia. OECD, Paris. 160 pp.(unseen) Singleton, F. (1985). National Parks and the Consenvation of Nature inYugoslavia. Paper presented at 3rd World Congress for Soviet and East European Studies. Washington DC. 30 October-4 November 1985.

Singleton, F. (in press, 1987). Environmental Protection in Yugoslavia.In: Schreiber, H. (Ed). Environmental Protection in Eastem Europe. IIUG, Berlin.

Singleton, F. (1987). Environmental protection in Yugoslavia. Research Unit Environmental Policy, Social Science Centre, Berlin.

UNEP/IG 20/Inf. 3 GE-80-2585 (1980). Survey of National Legislation relevant to Marine and Coastal Protected Areas. Report by the Legal Officer of the Food and Agriculture Organization of the United Nations based on the work of $\mathrm{Ch}$. du Saussay and M. Prieur. (unseen)

UNEP. (1987). Yugoslavia. UNEP Regional Bulletin for Europe. No 3 June 1987. p 8. (unseen)

Wirth, H. (Ed)(1979). Nature Reserves in Europe. Edition Leipzig. (unseen)

DATE September 1987; updated October 1990 


\section{Protected Area List}




\section{National Parks of the People's Socialist Republic of Albania}

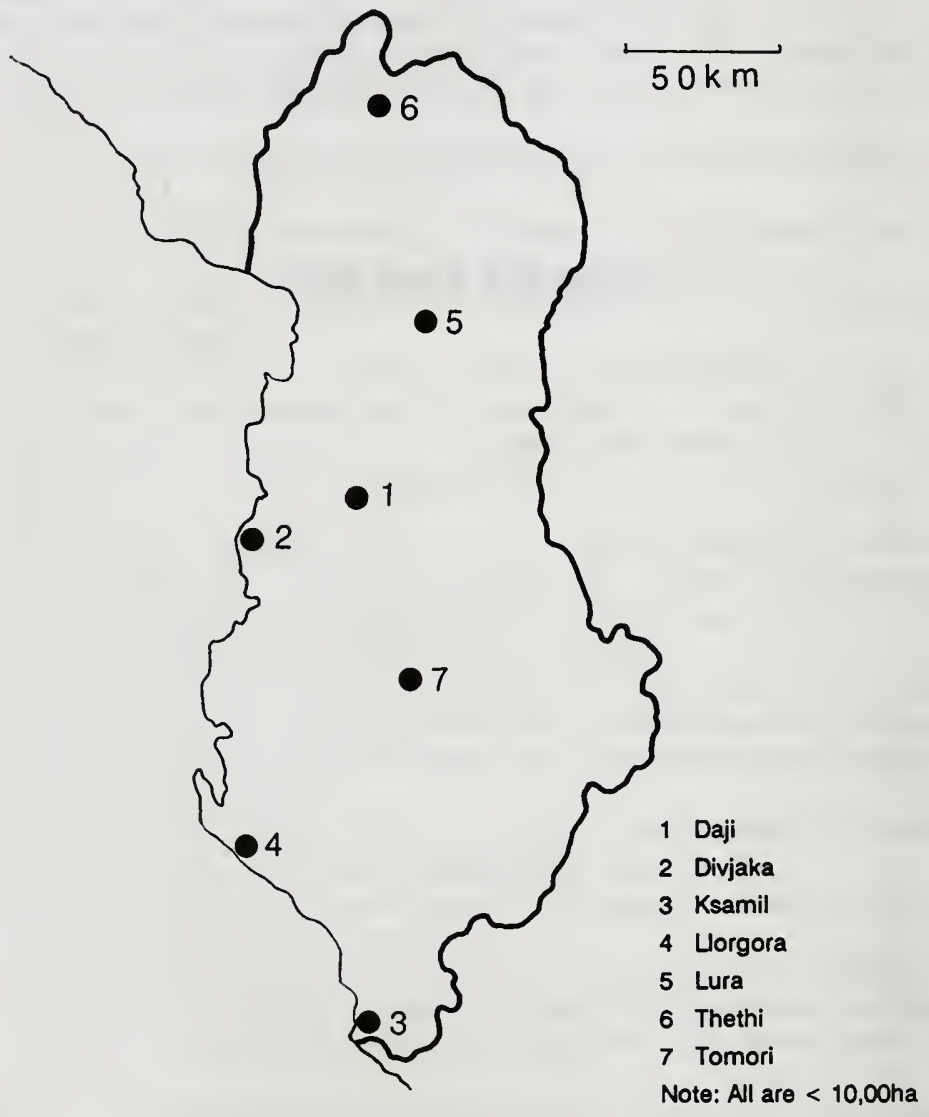




\section{ALBANIA}

\section{National Parks}

\section{Daji NP}

Divjaka NP

Ksamil NP

Llorgara NP

Lura NP

Thethi NP

Tomori NP

II

II

II

II

II

II

4,000

4,000

1966

1966

3,500

1966

4,000

1966

4,500

1966

3,000

1956

Nature Reserves

Berzan NR

Cangonj NR

Fushe-Senje (Kuqe Negel Patok) NR

Karaburum NR

Kuturman (Senisht Qerret Mirake) NR

Pishe Poro NR

IV

1,000

IV 3,000

IV 4,200

IV $\quad 12,000$

IV $\quad 4,000$

Prushkull (Potull) NR

IV $\quad 5,500$

IV $\quad 1,800$

Specially Protected Areas

Divjaka NP (SpPA)

SPA

1,000

1956

\section{BULGARIA}

\section{National Parks}

Chumensko plato NP

Etura NP

Melnishki pyramidi NP

Pirin NP

Roussenski Lom NP

Sinite kamani NP

Steneto NP

Vitosha NP

Zlatni pyassatzi NP

IV

II

III

\section{Botanical Reserves}




\section{National Parks of the People's Republic of Bulgaria}

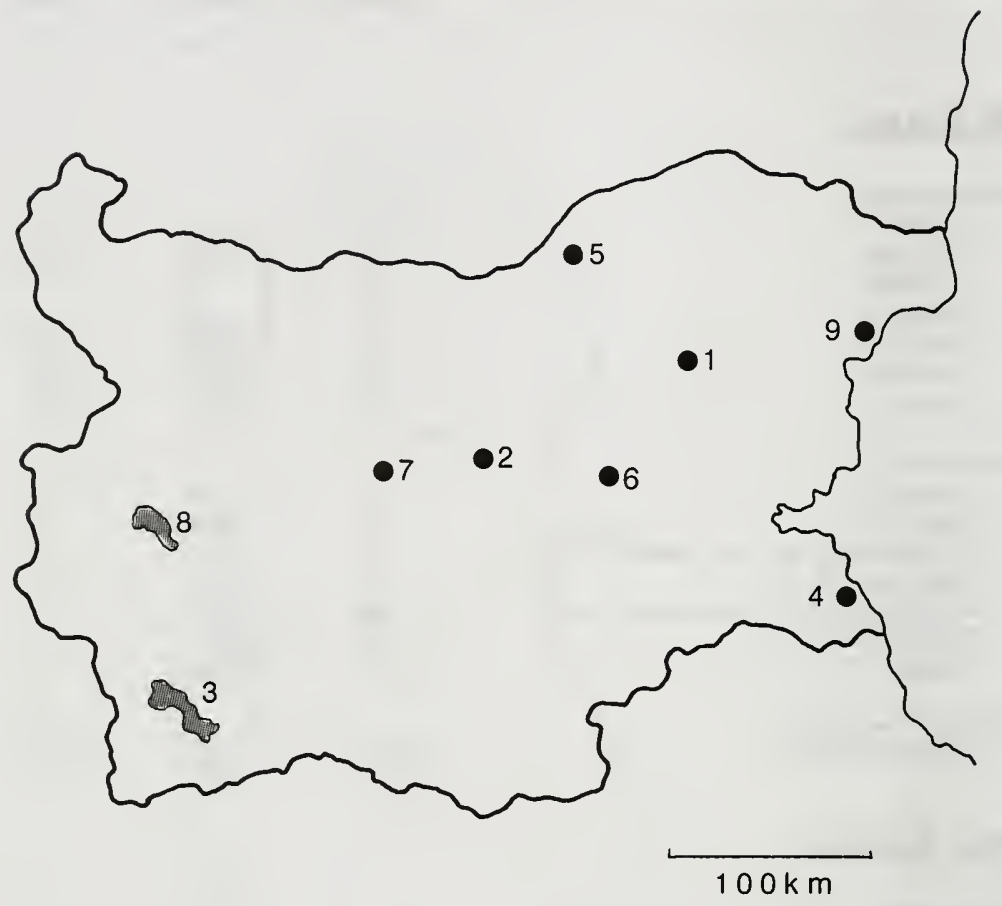

1 Chumensko plato

2 Etura

3 Pirin

4 Ropotamo

5 Roussenski Lom

6 Sinite kamani

7 Steneto

8 Vitosha

9 Zlatni pyassatzi

$>10,000 \mathrm{ha}$

$<10,000 \mathrm{ha}$ 
Bulgaria, contd .

Reserves

Alibotouch R

Atanassovsko ezero $R$

Baevi doupki-Djindjiritza $\mathbf{R}$

Bistrichko Branichte $\mathbf{R}$

Boatin R

Djendema $R$

Doupkata $\mathbf{R}$

Goliam Skakavetz R

Ibar $\mathbf{R}$

Kamenchtitza R

Kongura $\mathbf{R}$

Koupena $\mathbf{R}$

Maritchini ezera $\mathbf{R}$

Oreliar R

Parangalitza $\mathbf{R}$

Peechti skali R

Severen Djendem R

Sokolna R

Srebarna $\mathbf{R}$

Stara reka $\mathbf{R}$

Steneto $\mathbf{R}$

Tajansko jdrelo R

Tchouprene R

Tzaritchina $R$

Uzdini ezera $\mathbf{R}$

Vratchanski karst $\mathbf{R}$

Forest Resenves

Kamtchia FoR

Ouzounboudjak FoR

Rila Monastery FoR

$\begin{array}{rrr}\text { IV } & 1,445 & 1951 \\ \text { I } & 2,535 & 1956 \\ \text { I } & 3,446 & 1986\end{array}$

Biosphere Resenves

Parc national Steneto

Reserve Alibotouch

Reserve Bistrichko Branichte

Reserve Boatine

Reserve Djendema

Reserve Doupkata

Reserve Doupki-Djindjiritza

Reserve Koupena

$\begin{array}{ll}\text { IX } & 2,889 \\ \text { IX } & 1,628 \\ \text { IX } & 1,177 \\ \text { IX } & 1,281 \\ \text { IX } & 1,775 \\ \text { IX } & 1,210 \\ \text { IX } & 2,873 \\ \text { IX } & 1,084\end{array}$




\section{National Parks of the Czech and Slovak Federative Republic}

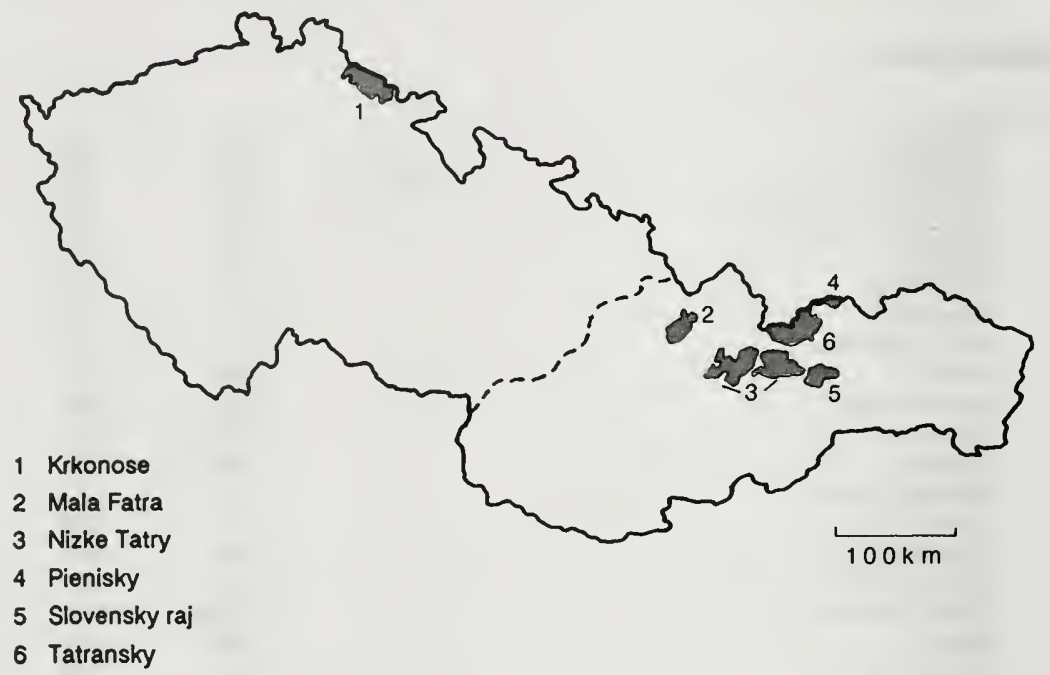


Bulgaria, contd .

Reserve Maritchini ezera

IX

1,510

1977

Reserve Ouzounboudjak

IX

2,575

1977

Reserve Parangalitza

IX

1,509

1977

Reserve Tchouprene

IX

1,440

1977

Reserve Tsaritchina

IX

1,420

1977

World Heritage Sites

Pirin National Park

$\mathbf{X}$

40,060

1983

\section{CZECHOSLOVAKIA}

\section{National Parks}

Krkonose NP

Mala Fatra NP

Nizke Tatry NP

Pieninsky NP

Slovensky raj NP

Tatransky NP

$\begin{array}{rrr}\text { V } & 38,500 & 1963 \\ \text { II } & 22,630 & 1988 \\ \text { II } & 81,095 & 1978 \\ \text { II } & 2,125 & 1967 \\ \text { II } & 19,763 & 1988 \\ \text { II } & 74,111 & 1948\end{array}$

National Nature Reserves

Adrspassko Teplicke skaly SPR

IV

1,772

1933

Choc SPR

Dropie SPR

Dumbier SPR

IV $\quad 1,428$

1982

IV

5,658

1955

Janska dolina SPR

IV

2,043

1973

IV $\quad 1,696$

1984

Javorina SPR

IV

11,589

Karlstejn SPR

Kokorinky dul SPR

Modravske slati SPR

Prameny labe SPR

Prameny upy SPR

Salatin SPR

Stara Reka SPR

Tlsta SPR

Vltavsky Luh SPR

Vychodokrkonosska SPR

IV

1,547

1954

1955

2,097

1953

3,615

1989

2,884

1980

4,280

1980

1,193

1982

1,197

1956

$\begin{array}{ll}\text { IV } & 3,066 \\ \text { IV } & 1,845\end{array}$

1981

Zapadokrkonosska SPR

IV $\quad 2,820$

IV 
Czechoslovakia, contd .e.

Biele Karpaty CHKO

Bile Karpaty CHKO

Blanik CHKO

Blansky les CHKO

Cerova vrchovina $\mathrm{CHKO}$

Ceske stredohori CHKO

Cesky kras CHKO

Cesky raj CHKO

Horna Orava CHKO

Jeseniky CHKO

Jizerske hory $\mathrm{CHKO}$

Kokorinsko CHKO

Krivoklatsko $\mathrm{CHKO}$

Kysuce $\mathrm{CHKO}$

Labske Piskovce CHKO

Luzicke Hory CHKO

Male Karpaty CHKO

Moravsky kras CHKO

Muranska planina CHKO

Orlicke hory $\mathrm{CHKO}$

Palava CHKO

Podyji CHKO

Polana CHKO

Ponitrie CHKO

Slavkowsky les CHKO

Slovensky kras CHKO

Stiavnicke vrchy $\mathrm{CHKO}$

Strazovske vrchy CHKO

Sumava CHKO

Trebonsko CHKO

Velka Fatra CHKO

Vihorlat CHKO

Vychodne Karpaty CHKO

Zahorie CHKO

Zdarske vrchy $\mathrm{CHKO}$

\section{Natural Areos}

Demanouske jaskyne CHPV

Udoli Oslavy a Chvojnice CHPV

Biosphere Reserves

Krivoklatsko Protected Landscape Area

\begin{tabular}{|c|c|c|}
\hline V & 43,519 & 1979 \\
\hline V & 71,500 & 1980 \\
\hline V & 4,000 & 1981 \\
\hline V & 21,235 & 1989 \\
\hline V & 16,280 & 1989 \\
\hline V & 107,000 & 1976 \\
\hline V & 13,000 & 1972 \\
\hline V & 12,500 & 1955 \\
\hline V & 70,333 & 1979 \\
\hline V & 75,000 & 1969 \\
\hline V & 35,000 & 1967 \\
\hline V & 27,000 & 1976 \\
\hline V & 62,792 & 1978 \\
\hline V & 65,462 & 1984 \\
\hline V & 30,000 & 1972 \\
\hline V & 35,000 & 1976 \\
\hline V & 65,504 & 1976 \\
\hline V & 12,000 & 1956 \\
\hline V & 21,930 & 1976 \\
\hline V & 20,000 & 1969 \\
\hline V & 7,000 & 1976 \\
\hline V & 10,300 & 1978 \\
\hline V & 20,079 & 1981 \\
\hline V & 37,665 & 1985 \\
\hline V & 64,000 & 1974 \\
\hline V & 36,165 & 1973 \\
\hline V & 77,630 & 1979 \\
\hline V & 30,979 & 1989 \\
\hline V & 160,000 & 1963 \\
\hline V & 70,000 & 1979 \\
\hline V & 60,610 & 1973 \\
\hline V & 4,383 & 1973 \\
\hline V & 66,810 & 1977 \\
\hline V & 27,522 & 1988 \\
\hline V & 71,500 & 1970 \\
\hline
\end{tabular}

III

IX

62,792

1977 
Czechoslovakia, contd ...

Palava Protected Landscape Area

Polana Biosphere Reserve

Slovensky Kras Protected Landscape Area

Sumava Biosphere Reserve

Trebon Basin Protected Landscape Area
IX

IX

IX

IX

IX

PRO

PRO

PRO

PRO

PRO

PRO

PRO

PRO

PRO
1986

1990

1977

1990

1977

\section{Litava CHKO}

Lucanska Mala Fatra CHKO

Slanske vrchy CHKO

Stolicke vrchy CHKO

Volouske vrchy CHKO

$(167,117)$

$(48,000)$

\section{EASTERN LÄNDER OF THE FRG}

\section{National Parks}

Boddenlandschaft NP

II

Jasmund NP

Muritz NP

Oberharz NP

Sachsische Schwoiz NP

II

1990

1990

1990

1990

Nature Reserves

Alter Stolberg NSG

Anklamer Stadtbruch NSG

Bucher Brack - Bolsdorfer Haken NSG

Der Bock und Hohe Duene Pramort NSG

Fischteiche in der Lewitz NSG

Galenbecker See NSG

Grosser Winterberg und Zschand NSG

Hinrichshagen NSG

Insel Hiddesec NSG

Insel Usedom NSG

Jasmund NSG

Oberharz NSG

Ostufer der Muritz NSG 


\section{National Parks of the Eastern Länder FRG}

1 Bottenlandschaft

2 Jasmund

3 Muritz

4 Oberharz

5 Sächsische Schowiz

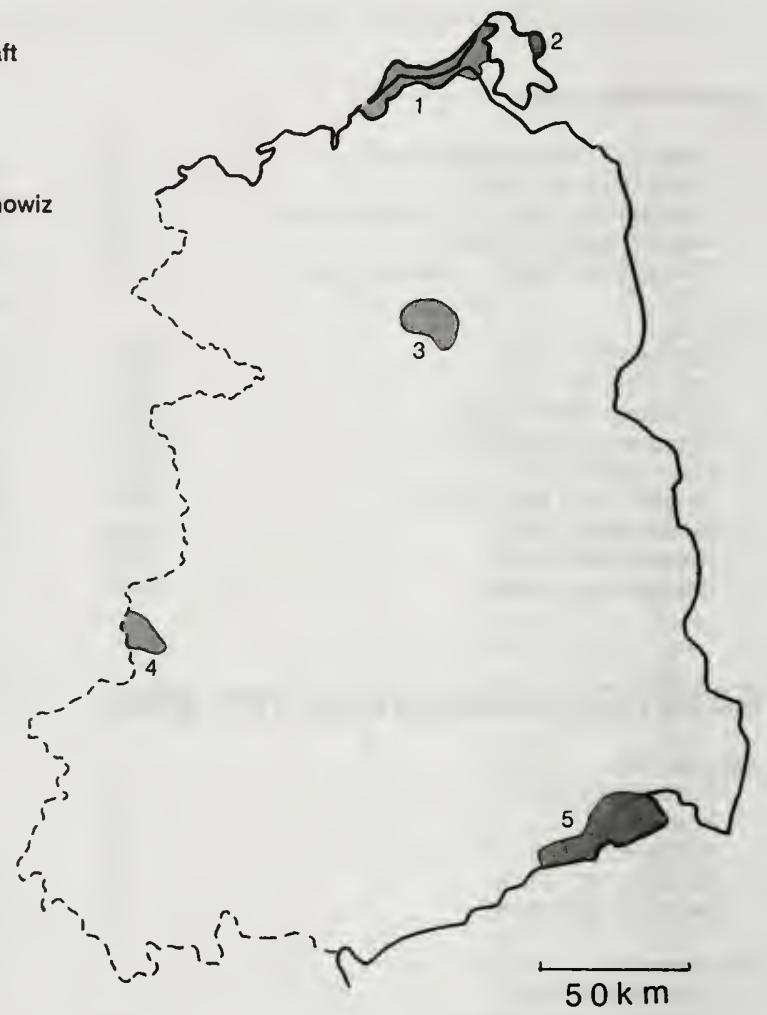


Eastern Länder/FRG, contd ...

Peenemunder Haken, Struck und Ruden NSG

IV

Peenetal-Moor NSG

Seegrund Ahlbeck NSG

Serrahn NSG

Stechlin NSG

Steckby-Loedderitzer Forst NSG

Uhlstaedter Heide NSG

Untere Mulde NSG

Vessertal NSG

Westdarsz und Darszer Ort mit Bernsteininsel NSG
IV

IV

IV

IV

IV

IV

IV

IV

IV
1,870

1,478

1,166

1,708

2,140

3,550

1,082

1,137

1,649

1,130

2,796

1,487

4,340

3,548

4,103

1,960

7,200

1,157

16,270

3,175

2,808

4,800

16,500

4,600

16,700

1,036

2,420

12,100

2,000

1,500

1,698

5,876

11,380

5,600

1,828

1,490

3,540

2,320

10,000

1,860
1925

1981

1961

1938

1961

1981

1961

1939

1957

1968

1968

1965

1964

1970

1965

1975

1968

1966

1966

1968

1968

1957

1963

1963

1974

1974

1964

1938

1961

1960

1971

1961

1963

1983

1968

1974

1960

1937

1968 
Eastern Länder/FRG, contd ...

Elsteraue zwischen Herzberg und Ubigau LSG

Elstemiederung u.s.w. LSG

Endmoranenzug Brohmer u.s.w. LSG

Fahner Hohe LSG

Feldberger Seenlandschaft LSG

Fischland-Darss-Zingst LSG

Flaming LSG

Flemsdorf LSG

Freiberger Mulde-Zschopau LSG

Friedewald und Moritzburger Teichgebiet LSG

Gamengrund LSG

Gebiet um Bad Wilsnack LSG

Geraer Stadtwald LSG

Gotzer Berge LSG

Grabentour LSG

Grosser See bei Furstenwerder LSG

Grosser und Kleiner Gleichberg LSG

Grosssteinberg-Ammelshain LSG

Grunau-Grunheider Wald-und Seengebiet LSG

Gubener Fliesstaler LSG

Gulitzer Endmorane und Kummerower See LSG

Haffkuste LSG

Hainleite LSG

Hakel LSG

Harbke-Allertal LSG

Harz LSG

Havelquellseen Kratzeburg LSG

Heiligenstadter Stadtwald LSG

Helmestausee LSG

Hiddensee LSG

Hildburghauser Wald LSG

Hohburger Berge LSG

Hohes Holz-Saures Holz mit ostlicem Vorland LSG

llmtal LSG

Insel Usedom LSG

Inselsee und Heidberg LSG

Jessener Berge LSG

Kleinseenplatte Neustrelitz LSG

Klocksiner Seenkette LSG

Knappensee LSG

Kohrener Land LSG

Konigshainer Berge LSG

\begin{tabular}{lrr} 
V & & \\
V & 2,160 & 1968 \\
V & 19,650 & 1968 \\
V & 5,000 & 1962 \\
V & 4,950 & 1970 \\
V & 7,000 & 1962 \\
V & 15,000 & 1966 \\
V & 38,670 & 1961 \\
V & 1,720 & 1965 \\
V & 7,000 & 1963 \\
V & 5,565 & 1977 \\
V & 2,390 & 1965 \\
V & 2,700 & 1964 \\
V & 1,575 & 1972 \\
V & 2,325 & 1966 \\
V & 2,864 & 1968 \\
V & 1,200 & 1962 \\
V & 1,988 & 1939 \\
V & 2,440 & 1963 \\
V & 21,700 & 1965 \\
V & 3,200 & 1968 \\
V & 9,000 & 1962 \\
V & 12,500 & 1962 \\
V & 5,976 & 1970 \\
V & 1,425 & 1939 \\
V & 22,770 & 1975 \\
V & 154,700 & 1960 \\
V & 2,600 & 1962 \\
V & 3,025 & 1960 \\
V & 1,717 & 1970 \\
V & 1,860 & 1955 \\
V & 5,250 & 1978 \\
V & 2,000 & 1963 \\
V & 7,240 & 1964 \\
V & 19,850 & 1960 \\
V & 37,500 & 1966 \\
V & 1,300 & 1964 \\
V & 1,025 & 1968 \\
V & 12,000 & 1962 \\
V & 20,000 & 1962 \\
V & 1,100 & 1968 \\
\hline & 17,000 & 1959 \\
4,855 & 1974
\end{tabular}


Eastern Länder/FRG, contd ...

Korbaer Teich und Lebusaer Waldgebiet LSG

Kothener See LSG

Krakower Seenlandschaft LSG

Kuhberg-Steinicht LSG

Kuhlung LSG

Kyffhauser LSG

Kyritzer Seenkette LSG

Lausitzer Grenzwall zwischen u.s.w. LSG

Lauta-Hoyerswerda-Wittichenau LSG

Lehniner Wald- und Seengebiet LSG

Leipziger Auewald LSG

Lewitz LSG

Lindenthaler Forst LSG

Lindhorst-Ramstedter Forst LSG

Linkselbische Taler zwiscen u.s.w. LSG

Ludwigsluster Schlosspark u.s.w. LSG

Lychen-Boitzenburg LSG

Madlitz-Falenhagener Seengebiet LSG

Malchiner Becken LSG

Markische Schweiz LSG

Merzdorf-Hirschfelder Waldhohen LSG

Mittelelbe LSG

Mittelheide LSG

Mittlere Mulde LSG

Mittlerer Strelasund LSG

Mittleres Saaletal LSG

Mittleres Warnowtal LSG

Mittleres Zschopautal LSG

Mockern-Magdeburgerforth LSG

Muhlhauser Stadtwald LSG

Muldental-Chemnitzal LSG

Muritz-Seen-Park LSG

Nauen-Brieselang LSG

Naunhof-Brandiser Forst LSG

Neisseaue im Kreis Forst LSG

Neuendorfer See LSG

Neuruppin-Rheinsberg u.s.w. LSG

Noitzscher-und Prellheide LSG

Nordliches Harzvorland LSG

Ober-Uecker-See LSG

Obere Saale LSG

Oberes Vogtland LSG
V

2,258

1,790

2,350

1,377

14,000

7,722

1,600

14,235

2,920

2,525

5,700

12,000

4,070

5,996

2,355

1,500

7,500

1,030

6,000

3,800

2,060

48,200

2,500

9,700

2,300

19,150

8,500

1,487

29,140

3,496

11,471

30,000

3,225

2,750

1,330

1,600

80,200

1,500

13,506

5,400

21,240

17,100
1968

1966

1955

1968

1966

1941

1958

1968

1968

1966

1959

1959

1975

1964

1974

1955

1962

1965

1962

1957

1968

1957

1969

1963

1966

1972

1964

1968

1975

1970

1968

1962

1966

1963

1968

1968

1966

1963

1961

1962

1965

1968 
Eastern Länder/FRG, contd ...

Oberes Westerzgebirge LSG

Oberes Zschopautal LSG

Oberlausitzer Bergland LSG

Osterzgebirge LSG

Ostrand der Arendseer Hochflache LSG

Ostrugen LSG

Parthenaue-Machern LSG

Peitzer Teichlandschaft mit Hammergraben LSG

Petersberg LSG

Plauer See LSG

Plothener Teichgebiet LSG

Potsdamer Havelseengebiet LSG

Pressnitztal LSG

Rabensteiner Wald-Pfaffenberg LSG

Rambower und Rudower See LSG

Rathenower Wald-und Seengebiet LSG

Rennsteigstreifen LSG

Rinne-Rotenbachtal LSG

Rippachtal LSG

Rodderaue LSG

Rotehofbachtal LSG

Saale LSG

Sachsische Schweiz LSG

Saidenbachtalsperre LSG

Salzwedel-Diesdorf LSG

Schaalsee und Heckenlandschaft Techin LSG

Scharmutzelsce-Storkower u.s.w. LSG

Schlaubetal LSG

Schweriner Seenlandschaft LSG

Schwielochsee LSG

Seendreieck bei Furstensee LSG

Seengebiet Warin-Neukloster LSG

Seenkette bei Comthurey LSG

Sewekow LSG

Spree-und Teichgebiet sudlich Uhyst LSG

Spreeniederung LSG

Spreewald LSG

Sprottetal LSG

Stadtwald Berlin LSG

Staubeckenlandschaft Brasinchen-Spremberg LSG

Steigerwald LSG

Stepenitztal LSG

\begin{tabular}{rrr} 
V & 17,015 & 1981 \\
V & 8,207 & 1968 \\
V & 30,730 & 1963 \\
V & 55,025 & 1968 \\
V & 7,210 & 1964 \\
V & 47,500 & 1966 \\
V & 1,300 & 1963 \\
V & 2,040 & 1968 \\
V & 1,730 & 1961 \\
V & 3,500 & 1957 \\
V & 1,896 & 1961 \\
V & 16,250 & 1966 \\
V & 2,300 & 1984 \\
V & 1,280 & 1962 \\
V & 1,500 & 1960 \\
V & 17,325 & 1966 \\
V & 3,900 & 1940 \\
V & 6,976 & 1970 \\
V & 2,880 & 1968 \\
V & 1,720 & 1960 \\
V & 2,444 & 1964 \\
V & 28,550 & 1961 \\
V & 36,810 & 1956 \\
V & 4,490 & 1962 \\
V & 13,310 & 1975 \\
V & 2,500 & 1958 \\
V & 10,600 & 1965 \\
V & 6,490 & 1965 \\
V & 4,300 & 1938 \\
V & 4,440 & 1965 \\
V & 3,200 & 1962 \\
V & 7,500 & 1938 \\
V & 1,200 & 1962 \\
V & 2,850 & 1966 \\
V & 1,210 & 1968 \\
V & 1,850 & 1974 \\
V & 28,700 & 1968 \\
V & 1,100 & 1984 \\
V & 7,548 & 1972 \\
V & 2,925 & 1968 \\
V & 1,188 & 1970 \\
V & 1,600 & 1958 \\
\hline & &
\end{tabular}


Eastern Länder/FRG, contd ..

Strausberger und Blumenthaler LSG

Striegistaler LSG

Sudlich von Zwickau LSG

Sudlicher Dromling LSG

Susser See LSG

Tal der Wilden Weisseritz LSG

Talsperre Kriebstein LSG

Talsperre Pirk LSG

Talsperre Pohl LSG

Talsperre Quitzdorf und Kollmer Hohen LSG

Templiner Seenkreuz LSG

Teupitz-Koriser Seengebiet LSG

Tharandter Wald LSG

Thummlitzwald LSG

Thuringer Wald LSG

Thuringische Rhon LSG

Tollense-Becken LSG

Torgelower See LSG

Triebischtaler LSG

Uchte-Tangerquellen LSG

Untere Havel LSG

Wald- und Restseengebiet Dobern LSG

Wald-u.Seengeb.z.Schwielochsee,Libe.u.Spree.LSG

Walder um Greiz und Werdau LSG

Waldgebiet Huy LSG

Waldgebiet bei Crivitz u. Barniner See ISG

Waldgebiet des Fallstein LSG

Wallensteingraben LSG

Wandlitz-Biesenthal-Prendener Seegebiet LSG

Webellinsee-Grimnitzsee LSG

Weidatalsperre LSG

Wermsdorfer Forst LSG

Westlausitz LSG

Wiesen-und Teichgebiet Eulo und Jamno LSG

Wiesen-und Teichlandschaft Kolkwitz-Hanchen LSG

Wolletzseengebiet LSG

Zeitzgrund ISG

Zichtauer Berge und Klotzer Forst LSG

Zitttauer Gebirge LSG

Zuwachs-Kulzauer Forst LSG

\begin{tabular}{rrr} 
V & 6,120 & 1965 \\
V & 4,233 & 1968 \\
V & 6,200 & 1968 \\
V & 2,556 & 1967 \\
V & 3,820 & 1954 \\
V & 1,415 & 1960 \\
V & 1,162 & 1968 \\
V & 1,432 & 1940 \\
V & 2,300 & 1962 \\
V & 4,417 & 1974 \\
V & 11,500 & 1962 \\
V & 23,317 & 1966 \\
V & 5,440 & 1974 \\
V & 11,500 & 1984 \\
V & 151,613 & 1963 \\
V & 61,500 & 1989 \\
V & 10,000 & 1962 \\
V & 3,000 & 1962 \\
V & 1,940 & 1974 \\
V & 6,681 & 1975 \\
V & 21,940 & 1967 \\
V & 1,850 & 1968 \\
V & 3,850 & 1968 \\
V & 5,525 & 1961 \\
V & 1,561 & 1939 \\
V & 1,000 & 1964 \\
V & 1,375 & 1939 \\
V & 2,000 & 1966 \\
V & 5,600 & 1965 \\
V & 3,790 & 1965 \\
V & 1,680 & 1961 \\
V & 13,000 & 1963 \\
V & 29,070 & 1974 \\
V & 1,440 & 1968 \\
V & 2,020 & 1968 \\
V & 7,000 & 1965 \\
V & 1,291 & 1958 \\
V & 10,800 & 1964 \\
V & 6,270 & 1958 \\
\hline & 5,040 & 1975 \\
\hline & &
\end{tabular}




\section{National Parks of the Republic of Hungary}

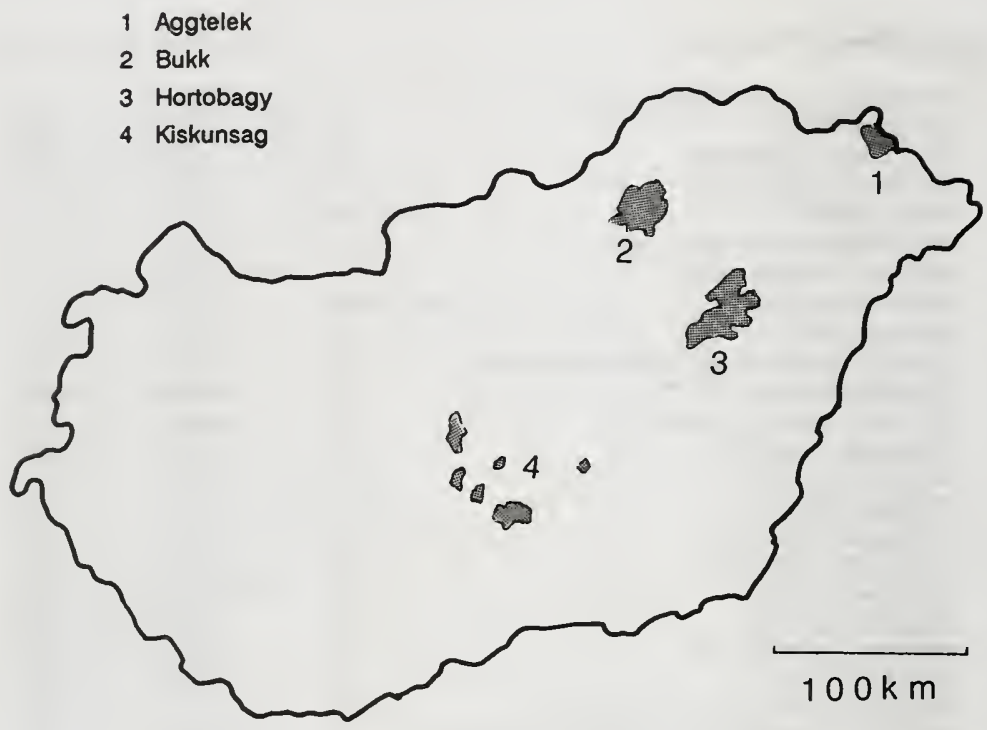


Country/Site type/Name of Area

Category Area (ha)

Year

Eastern Länder/FRG, contd ...

Biosphere Reserves

Middle Elbe Biosphere Reserve

Vessertal Nature Reserve

IX

17,500

1979

IX

7,460

1979

\section{HUNGARY}

National Parks

Aggtelek NP

Bukk NP

Hortobagy NP

Kiskunsag NP

$\begin{array}{lll}\text { V } & 19,708 & 1985 \\ \text { V } & 38,815 & 1976 \\ \text { V } & 52,000 & 1973 \\ \text { V } & 30,628 & 1975\end{array}$

Nature Conservation Areas

Agota-puszta NCA

Nagybereki Feher-viz NCA

Pusztakocsi mocsarak (Egyek) NCA

Tiszadobi arter NCA

Tiszafuredi madarrezervatum NCA

IV

1973

IV $\quad 1,000 \quad 1977$

IV $\quad 2,500 \quad 1973$

Landscape Protected Areas

Badacsonyi LPA

Barcsi osborokas LPA

Beda-Kora-Pancrai LPA

Borzsonyi LPA

Budai LPA

Devavanyai LPA

Ferto-tavi LPA

Gemenci LPA

Gerecsei LPA

Hajdirsagi LPA

Hansagi LPA

Kali-medence LPA

Kelet-Mecseki LPA

Keszthelyi-TK LPA

Kis-Balaton LPA

Koszegi LPA

Kozep-Tiszai LPA

Lazberci LPA

Martelyi LPA

Matrai LPA

Ocsai LPA

V

7,028
3,417
6,497
17,897
10,234
3,433
12,542
17,779
8,617
5,680
6,243
9,110
9,248
2,711
14,745
3,987
7,670
3,634
2,232
11,862
3,575

1965

1974

1989

1978

1978

1975

1977

1977

1977

1988

1976

1984

1977

1984

1986

1980

1978

1986

1971

1985

1975 


\section{National Parks of the Republic of Poland}

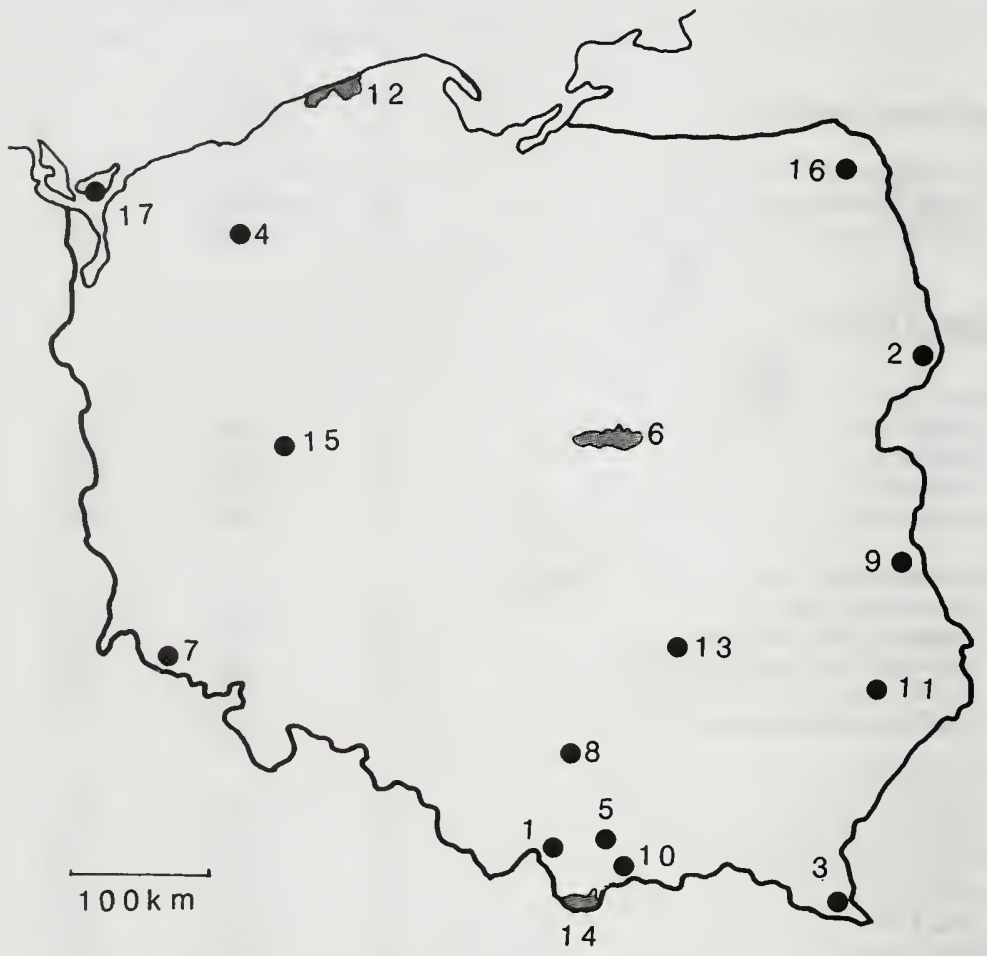
1 Babia Gora
11 Roztocze
2 Bialowieza
12 Slowinski
3 Bieszczady
13 Swietokrzyski
4 Drawski
14 Tatra
5 Gorce
15 Wielkopolski
6 Kampinos
16 Wigierski
7 Karkonosze
17 Wolinski
8 Ojcow
9 Polesti
$>10,000 \mathrm{ha}$
10 Pieniny
$<10,000 \mathrm{ha}$ 
Hungary, contd ...

Orgovanyi LPA

Orsegi LPA

Pilisi LPA

Pitvarai parztak LPA

Pusztaszeri LPA

Sarreti LPA

Soproni LPA

Szabadkigyosi LPA

Szatmar-Beregi LPA

Szentgyorgyvolgyi LPA

Szigetkozi LPA

Tihanyi LPA

Tokaj-Bodrogzugi LPA

Vertesi LPA

Zempleni LPA

Zselicsegi LPA

Biosphere Reserves

Aggtelek Biosphere Reserve

Hortobagy National Park

Kiskunsag Biosphere Reserve

Lake Ferto Biosphere Reserve

Pilis Biosphere Reserve

$\begin{array}{lrr}\text { V } & 2,953 & 1976 \\ \text { V } & 37,911 & 1978 \\ \text { V } & 23,323 & 1978 \\ \text { V } & 3,156 & 1989 \\ \text { V } & 22,151 & 1976 \\ \text { V } & 2,210 & 1985 \\ \text { V } & 4,905 & 1977 \\ \text { V } & 4,773 & 1987 \\ \text { V } & 22,246 & 1982 \\ \text { V } & 1,916 & 1976 \\ \text { V } & 9,158 & 1987 \\ \text { V } & 1,100 & 1952 \\ \text { V } & 4,242 & 1985 \\ \text { V } & 13,723 & 1976 \\ \text { V } & 26,496 & 1984 \\ \text { V } & 9,042 & 1976\end{array}$

$\begin{array}{lll}\text { IX } & 19,247 & 1979 \\ \text { IX } & 52,000 & 1979 \\ \text { IX } & 22,095 & 1979 \\ \text { IX } & 12,542 & 1979 \\ \text { IX } & 23,000 & 1980\end{array}$

\section{POLAND}

National Parks

Babia Gora NP

Bialowieza NP

Bieszczady NP

Drawski NP

Gorce NP

Kampinos NP

Karkonosze NP

Ojcow NP

Pieniny NP

Poleski NP

Roztocze NP

Slowinski NP

Swietokrzyski NP

$\begin{array}{lrr}\text { II } & 1,734 & 1933 \\ \text { II } & 5,317 & 1932 \\ \text { II } & 15,337 & 1973 \\ \text { II } & 8,691 & 1990 \\ \text { II } & 6,750 & 1981 \\ \text { II } & 35,486 & 1959 \\ \text { II } & 5,563 & 1959 \\ \text { V } & 1,592 & 1956 \\ \text { II } & 2,329 & 1932 \\ \text { II } & 4,813 & 1990 \\ \text { II } & 6,857 & 1974 \\ \text { II } & 18,247 & 1967 \\ \text { II } & 5,906 & 1950\end{array}$


Poland, contd -

Tatra NP

Wielkopolski NP

Wigierski NP

Wolinski NP

Nature Resenves

Czerwone Bagno NR (Faunal-Peatbog Reserve)

Jata NR (Floral Reserve)

Jezioro Dobskic NR (Landscape)

Jezioro Druzno NR (Bird Reserve)

Jezioro Kosno NR (Landscape )

Jezioro Nidzkie NR (Landscape)

Jezioro Siedmiu Wysp NR (Bird Reserve)

Kurianskie Bagno NR (Floral Reserve)

Las Warminski NR (Forest Reserve)

Lasy Janowskie NR (Forest Reserve)

Nadgoplanski Park Tysiaclecia NR (Landscape)

Paslece NR (Faunal Reserve)

Puszcza Bialowieska NR (Landscape)

Rzeka Drweca NR (Water Reserve)

Slonsk NR (Faunal-Peatbog Reserve)

Stawy Milickie NR (Bird Reserve)

Stawy Przemkowskie NR (Bird Reserve)

Wielki Bytyn NR

Wielki NR (Faunal Reserve)

Obszar Chronionego Krajobrazu

Baltowskim OCK

Busko-Zdroj OCK

Checinsko-Malogoskim OCK

Dolina Radwi OCK

Dolina Wkry i dolnego biegu rzeki Lydyni OCK

Jezioro Szczecineckie OCK

Kieleckie OCK

Koneckim OCK

Koszalinski Pas Nadmorski OCK

Obszar lesny na poludnie od Lidzbarka i

Okolice Kalisza Pomorskiego OCK

Okolice Mlawy i Ilowa OCK

Okolice Polanowa OCK

Okolice Regimina OCK

Okolice Zydowo-Bialy Bor OCK

$\begin{array}{lrr}\text { II } & 21,164 & 1955 \\ \text { II } & 5,198 & 1933 \\ \text { V } & 14,840 & 1989 \\ \text { II } & 4,844 & 1960\end{array}$

IV

11,630

1,117

1,833

3,022

1,232

2,935

1,000

1,714

1,798

2,677

12,684

4,116

1,357

1,287

4,166

5,324

1,046

1,826

4,116

1957

1952

1976

1967

1982

1973

1956

1985

1982

1984

1967

1970

1969

1961

1977

1963

1984

1989

1970

1973

1973

1973

1975

1977

1975

1973

1973

1975

1975

1975

1975

1975

1975

1975 
Poland, contd ...

Pilicy OCK

VIII

Pojezierze Drawskie OCK

VIII

Srodkowy odcinek na prawnym brzegu Narwi OCK

VIII

Staszowskim OCK

VIII

Szydlowieckim OCK

VIII

Wloszczowskim OCK

Wschodnio-Beskidzki OCK

Zagnansko-Suchedniowskim OCK

VIII

VIII

VIII

$\begin{array}{rr}7,000 & 1973 \\ 100,053 & 1975 \\ 6,600 & 1975 \\ 1,400 & 1973 \\ 2,900 & 1093 \\ 4,100 & 1973 \\ 162,800 & 1972 \\ 21,000 & 1973\end{array}$

\section{Landscape Parks}

Bolimowski PK

Brodnickj PK

Chelmski PK

Doliny Slupi PK

Drawski PK

Gor Opawskich PK

Gory Sw. Anny PK

Gostyn sko-Wloclawski PK

Inski PK

Kaszubski PK

Kazimierski PK

Kozienicki PK

Krasnabrodzki PK

Ksiazanski PK

Lagowski PK

Lasy Janowskie PK

Mazowiecki PK

Mazurski PK

Mierzeja Wislana PK

Nadmorski PK

Narwianski PK

Poleski PK

Popradzki PK

Przedborski PK

Pszczewski PK

Puszczy Knyszynskiej PK

Puszczy Solskiej PK

Slezanski PK

Snieznickj PK

Sobiborskj PK

Stolowogorski PK

Strzelecki PK

\begin{tabular}{rrr} 
V & 25,900 & 1986 \\
V & 22,240 & 1985 \\
V & 23,500 & 1983 \\
V & 120,201 & 1981 \\
V & 63,642 & 1979 \\
V & 4,830 & 1988 \\
V & 5,780 & 1988 \\
V & 51,344 & 1979 \\
V & 51,843 & 1982 \\
V & 34,544 & 1983 \\
V & 38,670 & 1979 \\
V & 45,535 & 1983 \\
V & 40,184 & 1988 \\
V & 4,500 & 1981 \\
V & 10,070 & 1985 \\
V & 62,950 & 1984 \\
V & 25,510 & 1986 \\
V & 69,219 & 1977 \\
V & 22,390 & 1985 \\
V & 27,610 & 1978 \\
V & 47,915 & 1985 \\
V & 27,500 & 1983 \\
V & 78,000 & 1987 \\
V & 31,120 & 1988 \\
V & 57,587 & 1986 \\
V & 125,349 & 1988 \\
V & 115,246 & 1988 \\
V & 12,200 & 1988 \\
V & 28,800 & 1981 \\
V & 19,000 & 1983 \\
V & 13,600 & 1981 \\
V & 10,300 & 1983 \\
\hline & &
\end{tabular}




\section{National Parks of Romania}

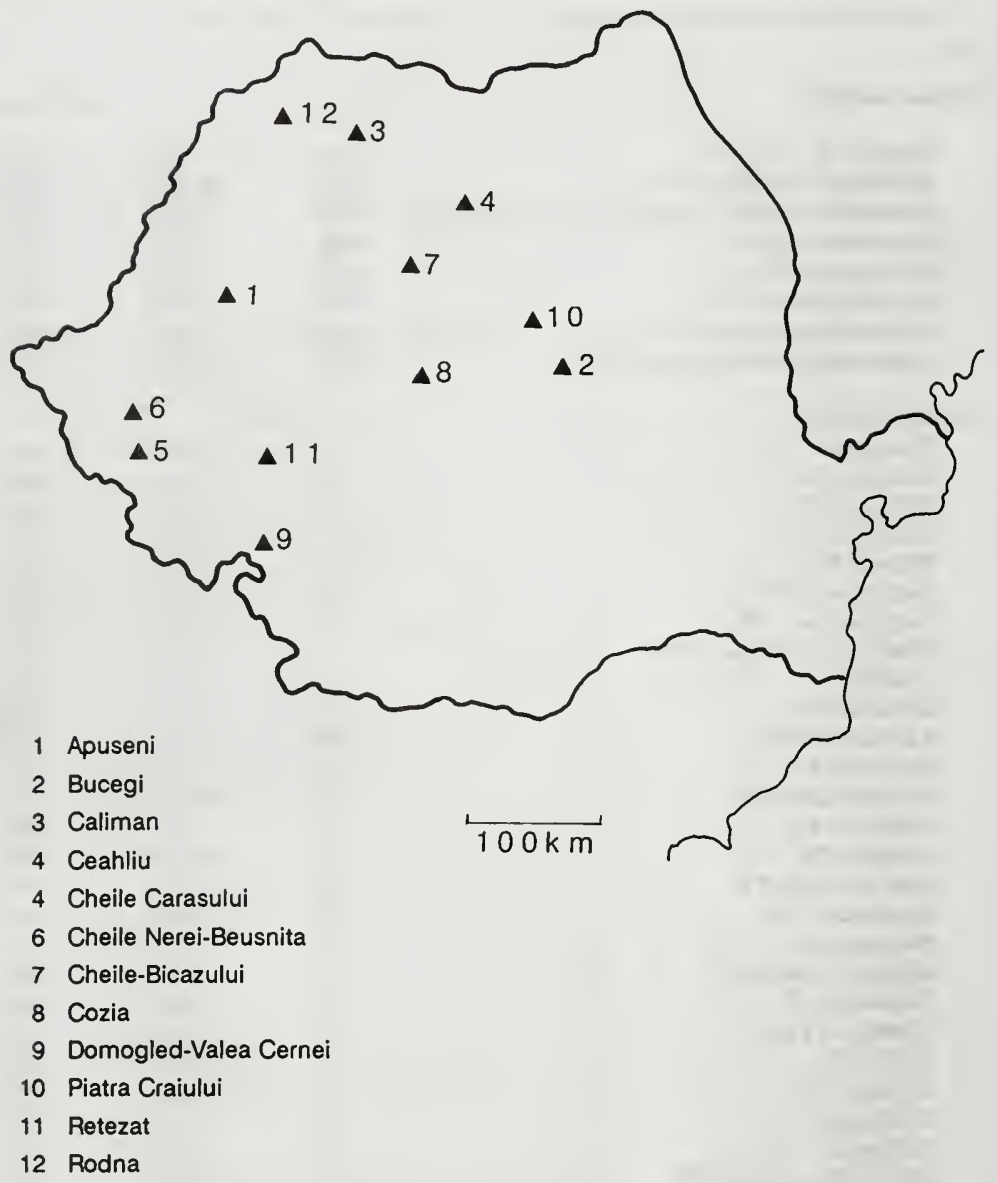


Poland, contd ...

Suwalski PK
Szczecinski PK
Trojmiejski PK
Tucholski PK
Wdzydzki PK
Wigierski PK
Wzniesienie Elblaskie PK
Zaleczanski PK
Zespol Jurajskich PK
Zespol Parkow Ponidzia PK
Zespol Swietokrzyskie PK
Zywiecki PK

Biosphere Reserves

Babia Gora National Park

Bialowieza National Park

Slowinski National Park

World Heritage Sites

Bialowieza National Park

\section{Proposed}

Biebrzanski NP

Mazurski NP

Stolowogorski NP

Szczecinski NP

\section{ROMANIA}

\author{
National Parks \\ Apuseni NP \\ Bucegi NP \\ Caliman NP \\ Ceahliu NP \\ Cheile Carasului NP \\ Cheile Nerei-Beusnita NP \\ Cheile-Bicazului NP \\ Cozia NP \\ Domogled-Valea Cernei NP \\ Piatra Craiului NP \\ Retezat NP
}

$\begin{array}{lrr}\text { V } & 14,901 & 1976 \\ \text { V } & 22,384 & 1982 \\ \text { V } & 33,107 & 1979 \\ \text { V } & 52,928 & 1985 \\ \text { V } & 17,650 & 1983 \\ \text { V } & 21,301 & 1976 \\ \text { V } & 33,292 & 1985 \\ \text { V } & 14,278 & 1979 \\ \text { V } & 246,276 & 1980 \\ \text { V } & 82,648 & 1986 \\ \text { V } & 100,625 & 1988 \\ \text { V } & 57,587 & 1986\end{array}$

$\begin{array}{rrr}\text { IX } & 1,741 & 1976 \\ \text { IX } & 5,316 & 1976 \\ \text { IX } & 18,069 & 1976\end{array}$

X

PRO

PRO

PRO

PRO
1982

1985

1983

1976

1985

1980

1986

1986

1976

1976

$(4,000)$ 
Romania, contd ...

Rodna NP

\section{Narure Reserves}

Bicaz (narrow Gorge) and Lacul Rosu NR

Bucegi NR

Caliman NR

Cheile Bicazului NR

Cheile Carasului NR

Cheile Nerei-Beusnita NR

Cozia NR

Padurea-Letea NR

Perisor-Zatoane-Sacalin NR

Periteasca-Gura Portita NR

Piatra Craiului NR

Pietrile Boghii-Pietroasa NR

Pietrosu Mare NR

Rosca-Buhaiova-Hrecisca NR

Rosca-Letea NR

Saritoarea Bohodejului NR

Scarisoara-Belioara NR

Sesul Craiului-Belicara NR

Sfintu Gheorghe-Perisor-Palade NR

Snagov Forest and Snagov Lake NR

\section{Nature Parks}

Gradistea Muncelului-Cioclovina NatP

\section{Forest Reserves}

Ceahlau-Politele cu crini FoR

Domogled-Tesna-Virful lui Stan FoR

Tismana FoR

Biosphere Resenves

Pietrosul Mare Nature Reserve

Retezat National Park

Rosca-Letea Reserve

\section{Unclassified}

Bila-Lala NR

Proposed

Delta Dunarii NP
V

56,700

1990

IV

5,369

3,748

IV

1,625

IV

3,241

IV $\quad 1,025$

$\begin{array}{lr}\text { IV } & 11,098 \\ \text { IV } & 7,284\end{array}$

IV

V

IV

IV

IV

IV

IV

IV

IV

IV

IV

IV

5,212

16,400

3,900

1,459

1,737

5,865

14,600

16,400

1,950

6,507

6,507

15,000

1,767

1955

1943

1955

1982

1943

1938

1961

1961

1958

1971

1932

1961

1961

1981

1941

1941

1952

V

6,030

1979

IV

IV

IX

3,068

1979

IX

20,000

1979

IX

18,145

1979

IV

5,135

1973

PRO 
Romania, contd -

Drocea NP

PRO

Histria (Grindul Lupilor Marchelul) NR

PRO

$(1,410)$

\section{UNION OF SOVIET SOCIALIST REPUBLICS}

Biosphere Reserves

Biosphere Reserve of the West Estonian Archipelago

IX

$1,560,000$

1990

Lake Baikal Region Biosphere Reserve

IX 559,100

1986

U.S.S.R. - Armenia S.S.R.

National Parks

Sevan NP

II

150,000

1978

Zapovedniki

Dilizhanskiy $\mathbf{Z}$

Khosrovskiy $\mathbf{Z}$

Shikaokhskiy Z

24,232

\section{U.S.S.R. - Azerbaydzhan S.S.R.}

\section{Zapovedniki}

Ak-Gel'skiy Z

Geigel'skiy Z

Girkanskiy Z

Ilisuinsky Z

Ismaillinskiy $\mathbf{Z}$

Karayazskiy $\mathbf{Z}$

Kyzyl-Agachskiy Z

Pirkulinskiy $\mathbf{Z}$

Shirvanskiy $\mathbf{Z}$

Turianchaiskiy $\mathbf{Z}$

Zakatal'skiy Z

U.S.S.R. - Byelorussian S.S.R.

Zapovedniki

Berezinskiy Z

Prypyatskiy Z 


\section{National Parks of the Western Republics of the Soviet Union}

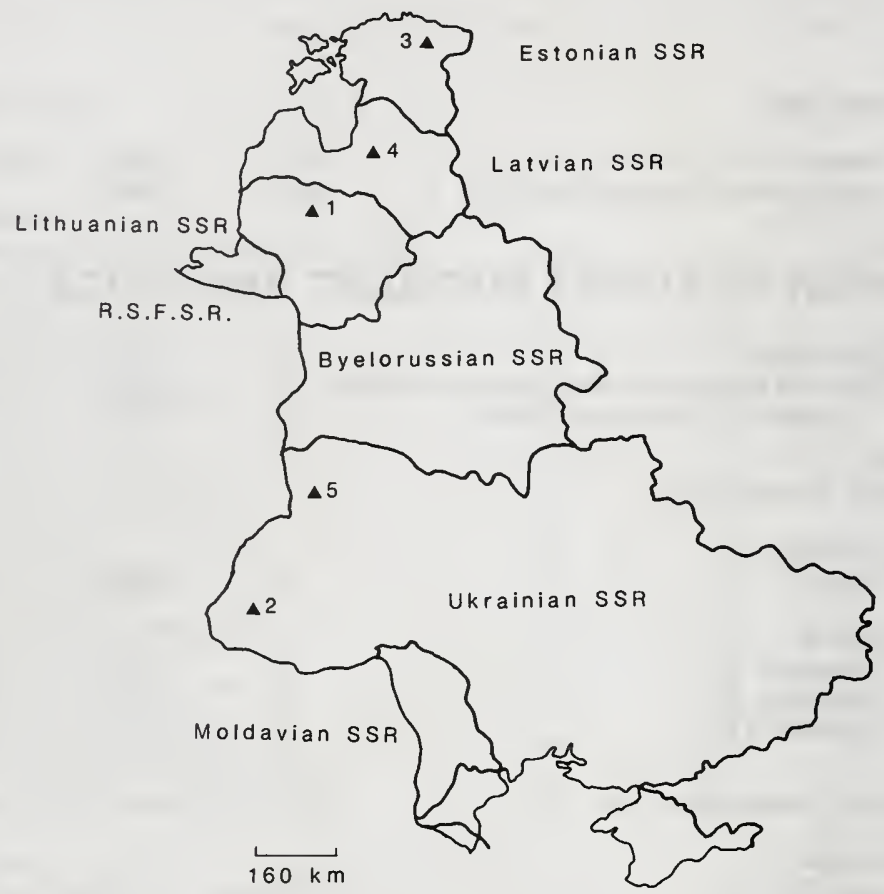

\section{Estonlan S.S.R.: 3 Lakhemaaskiy}

\section{Latvian S.S.R: $\quad 1$ Gauya}

Lithuanian S.S.R: 4 Lithuanian

Ukrainian S.S.R: 2 Karpatskiy

5 Shatskiy 
Byelorussian S.S.R, contd ..

Hunting Reserves

Belovezhskaya Pushcha HR

Telekhanskoye HR

IV

87,577

1940

IV $\quad 10,947$

1977

Biosphere Reserves

Berezinskiy Zapovednik

IX

76,201

1978

U.S.S.R - Estonia S.S.R.

National Parks

Lakhemaaskiy NP

II

64,911

1971

\section{Zapovedniki}

Endlaskiy Z

Matsaluskiy Z

Nigulasskiy Z

Vil'sandiyskiy Z

Viydumyaeskiy Z

$\begin{array}{lrl}\text { I } & 8,162 & 1985 \\ \text { I } & 39,697 & 1957 \\ \text { I } & 2,771 & 1957 \\ \text { I } & 10,689 & 1910 \\ \text { I } & 1,194 & 1957\end{array}$

U.S.S.R. - Georgia S.S.R.

National Parks

Tbilisskiy NP

II

19,410

1973

Zapovedniki

Adzhametskiy $\mathbf{Z}$

Akhmetskiy Z

Algetskiy Z

Borzhomskiy Z

Kazbegskiy Z

Kintrishskiy Z

Lagodekhskiy Z

Liakhvskiy Z

Mariamdzhvarskiy $\mathbf{Z}$

Pitsyundo-Myusserskiy Z

Pskhu-Gumistinskiy Z

Ritsinskiy Z

Saguramskiy Z

Vashlovanskiy $\mathbf{Z}$ 


\section{National Parks of the Central and Eastern Republics of the Soviet Union}

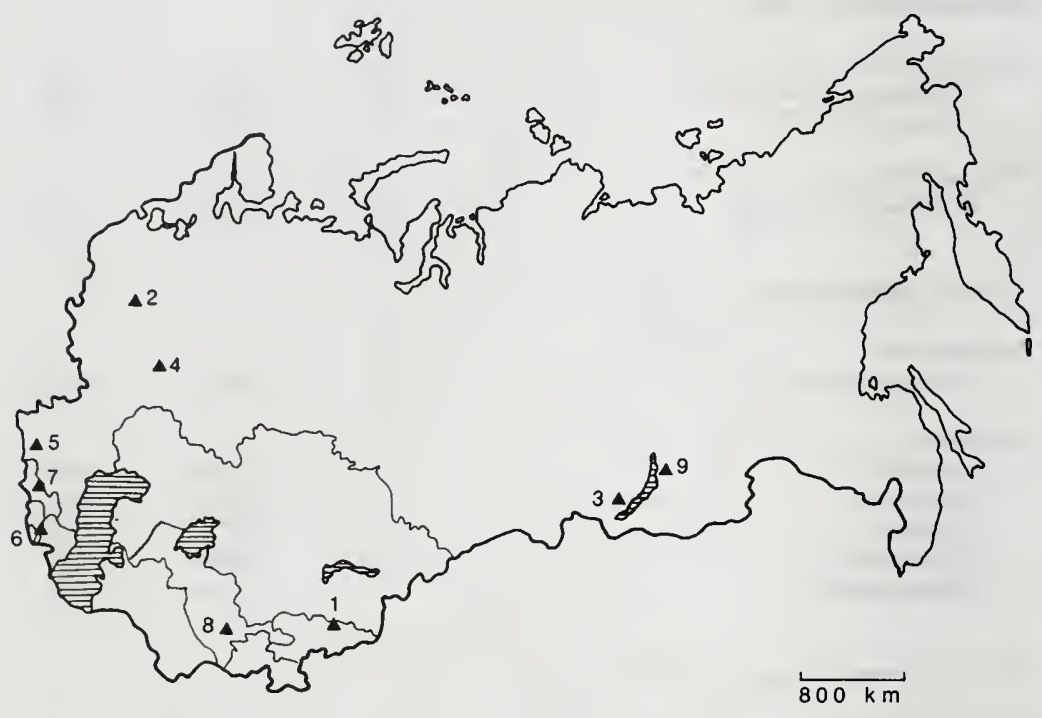

1 Aa-Aroha

2 Losinyy Ostrov

3 Pribaikalski

4 Samarskaya Luka

5 Sochinskiy

6 Sevan

7 Tbilisskiy

8 Uzbekskoy (Uzbekistan People's Park)

9 Zaibaikalski 


\section{U.S.S.R. - Kazakhstan S.S.R.}

\section{National Parks}

Bayanaul'sky NP

II

45,500

1985

Zapovedniki

Aksu-Dzhabagly Z

Alma-Atinskiy Z

Barsakel'messkiy Z

Kurgal'dzhinskiy Z

Markakol'skiy Z

Naurzumskiy Z

Ustiyurtskiy Z

$\begin{array}{rrr}\text { I } & 75,094 & 1927 \\ \text { I } & 73,342 & 1961 \\ \text { I } & 18,300 & 1939 \\ \text { I } & 237,138 & 1968 \\ \text { I } & 75,040 & 1976 \\ \text { I } & 87,694 & 1934 \\ \text { I } & 223,300 & 1984\end{array}$

Ramsar Wetland Sites

Kourgal'dzhin and Tengiz Lakes RW

Lakes of the Lower Turgay and Irgiz RW

R $\quad 260,500$

1976

R 348,000

\section{U.S.S.R - Kirghizia S.S.R.}

National Parks

Ala-Archa NP

II

19,400

1976

Zapovedniki

Besh-Aral'skiy Z

Issyk-Kul'skiy Z

Narynskiy Z

Sary-Chelekskiy Z

I 116,732

1979

I 18,999

1948

18,260

1983

23,868

1959

Ramsar Wetland Sites

Issyk-kul Lake RW

R

629,800

Biosphere Resenves

Chatkal Mountains Biosphere Reserve

IX

71,400

1978

U.S.S.R. - Latvia S.S.R.

National Parks

Gauya NP

II

83,750

1973

Zapovedniki

Grini Z 
Latvia S.S.R, contd ...

Krustkalny Z

Slitere Z

Teychi Z
2,902

1977

15,037

1921

19,047

\section{U.S.S.R - Lithuania S.S.R}

National Parks

Lithuanian SSR NP

II

30,000

1974

\section{Zapovedniki}

Chapkyalyay Z

Kamanos Z

Zhuvintas Z

\section{U.S.S.R. - Moldavia S.S.R.}

\section{Zapovedniki}

Kodry Z

Redenskiy Les Z

\section{U.S.S.R - R.S.F.S.R}

\section{National Parks}

Bashkiriya NP

Losinyy Ostrov NP

Mariy Chodra NP

Pribaikalskiy NP

Priel'brusskiy NP

Samarskaya Luka NP

Sochinskiy NP

Zabaikalskiy NP

$\begin{array}{rrr}\text { II } & 98,134 & 1986 \\ \text { II } & 10,058 & 1983 \\ \text { II } & 36,600 & 1985 \\ \text { II } & 412,750 & 1986 \\ \text { II } & 101,000 & 1986 \\ \text { II } & 128,000 & 1984 \\ \text { II } & 190,000 & 1983 \\ \text { II } & 269,300 & 1986\end{array}$

\section{Zapovedniki}

Altaiskiy Z

Astrakhanskiy Z

Azas Z

Baikalo-Lenskiy Z

Barguzinskiy Z

Bashkirskiy Z 
R.S.F.S.R, contd .

Bassegi Z

Baykal'skiy Z

Bol'shekhekhtsizskiy Z

Bryanskiy Les Z

Bureinskiy $\mathbf{Z}$

Dagestanskiy Z

Dal'nevostochnyy Z

Darvinskiy Z

Dauzsky Z

Il'menskiy Z

Kabardino-Balkarskiy Z

Kandalakshskiy Z

Kavkazskiy Z

Kedrovaya Pad' Z

Khinganskiy Z

Khoperskiy Z

Kivach Z

Komsomol'skiy Z

Kostomukhskiy Z

Kronotskiy Z

Kuril'skiy Z

Laplandskiy Z

Lazovskiy $\mathbf{Z}$

Les na Vorskle Z

Magadanskiy Z

Malaya Sos'va Z

Mordovskiy Z

Nizhne-Svirskiy Z

Okskiy Z

Olekminskiy $\mathbf{Z}$

Ozenbuzgskiy Z

Pechoro-Ilychskiy Z

Pinezhskiy Z

Pozonaiskiy $\mathbf{Z}$

Prioksko-Terrasnyy Z

Putozanskiy Z

Sayano-Shushenskiy Z

Severo-Osetinskiy $\mathbf{Z}$

Shul'gan Tash Z

Sikhote-Alinskiy Z

Sokhondinskiy Z

Stolby Z

19,422

165,724

45,123

11,778

358,444

19,061

64,316

112,630

631,300

30,380

74,099

58,100

263,277

17,897

97,836

16,178

10,460

63,866

47,457

$1,099,000$

65,365

278,436

116,524

1,038

883,805

92,921

32,148

40,972

22,911

847,102

21,653

721,322

41,244

56,669

4,945

$1,887,251$

390,368

28,999

22,531

347,052

211,007

47,154
1982

1969

1963

1987

1987

1987

1978

1945

1986

1920

1976

1932

1924

1916

1963

1935

1931

1963

1983

1967

1984

1930

1957

1979

1982

1976

1935

1980

1935

1984

1989

1930

1975

1988

1948

1988

1976

1967

1986

1935

1973

1925 
R.S.F.S.R, contd

Taymyrskiy Z
Teberdinskiy Z
Tsentral'nochernozemnyy Z
Tsentral'novesnoy Z
Tsentralno-Sibirskiy Z
Ussuriyskiy Z
Ust'Lenskiy Z
Verkhne-Tazovskiy Z
Visimskiy Z
Vitimskiy Z
Volzhsko-Kamskiy Z
Voronezhskiy Z
Vrangel Island Z
Yuganskiy Z
Yuzhno-Uzalskiy Z
Zavidovskiy Z
Zeyskiy Z
Zhigulevskiy Z

Biosphere Resenves

Astrakhanskiy Zapovednik

Barguzinskiy Zapovednik

Kavkazskiy Zapovednik

Kronotskiy Zapovednik

Laplandskiy Zapovednik

Oka River Valley Biosphere Reserve

Pechoro-Ilychskiy Zapovednik

Sayano-Shushenskiy Zapovednik

Sikhote-Alin Zapovednik

Sokhondinskiy Zapovednik

Tsentral'nochernozem Zapovednik

Tsentral'nolesnoy Zapovednik

Tzentralnosibirskii Biosphere Reserve

Voronezhskiy Zapovednik

$\begin{array}{lrr}\text { IX } & 63,400 & 1984 \\ \text { IX } & 263,176 & 1916 \\ \text { IX } & 263,477 & 1978 \\ \text { IX } & 1,099,000 & 1984 \\ \text { IX } & 278,400 & 1984 \\ \text { IX } & 45,845 & 1978 \\ \text { IX } & 721,322 & 1984 \\ \text { IX } & 389,570 & 1984 \\ \text { IX } & 340,200 & 1978 \\ \text { IX } & 211,000 & 1984 \\ \text { IX } & 4,795 & 1978 \\ \text { IX } & 21,348 & 1985 \\ \text { IX } & 5,000,000 & 1986 \\ \text { IX } & 31,053 & 1984\end{array}$

\section{U.S.S.R - Tadzhikistan S.S.R.}

\section{Zapovedniki}

Dashti-Dzhumskiy Z

Ramit Z

Tigrovaya Balka Z 


\section{U.S.S.R. - Turkmenistan S.S.R.}

\section{Zapovedniki}

Amu-Dar'inskiy Z

Badkhyzskiy Z

Kaplankyrskiy Z

Kopetdagskiy $\mathbf{Z}$

Krasnovodskiy Z

Kugitangskiy Z

Repetekskiy Z

Syunt-Khasardagskiy Z

$\begin{array}{rrr}\text { I } & 87,680 & 1941 \\ \text { I } & 570,000 & 1979 \\ \text { I } & 49,793 & 1976 \\ \text { I } & 262,037 & 1928 \\ \text { I } & 27,100 & 1986 \\ \text { I } & 34,600 & 1928 \\ \text { I } & 29,700 & 1976\end{array}$

Ramsar Wetland Sites

Krasnovodsk and North-Cheleken Bay RW

R $\quad 188,700$

Biosphere Reserves

Repetek Zapovednik

IX

34,600

1978

\section{U.S.S.R. - Ukrainian S.S.R.}

National Parks

Karpatskiy NP

II $\quad 50,303$

Shatskiy NP

II

82,500

1983

\section{Zapovedniki}

Askaniya Nova Z

Dunaiskie Plavni Z

Kanevskiy Z

Karadagskiy Z

Karpatskiy Z

Luganskiy Z

Polesskiy Z

Rastoch'e Z

Ukrainskiy Stepnoy Z

Yaltinskiy Z

Hunting Reserves

Azovo-Sivashskoye HR

Dneprovsko-Teterevskoye HR 


\section{National Parks of the Socialist Federal Republic of Yugoslavia}

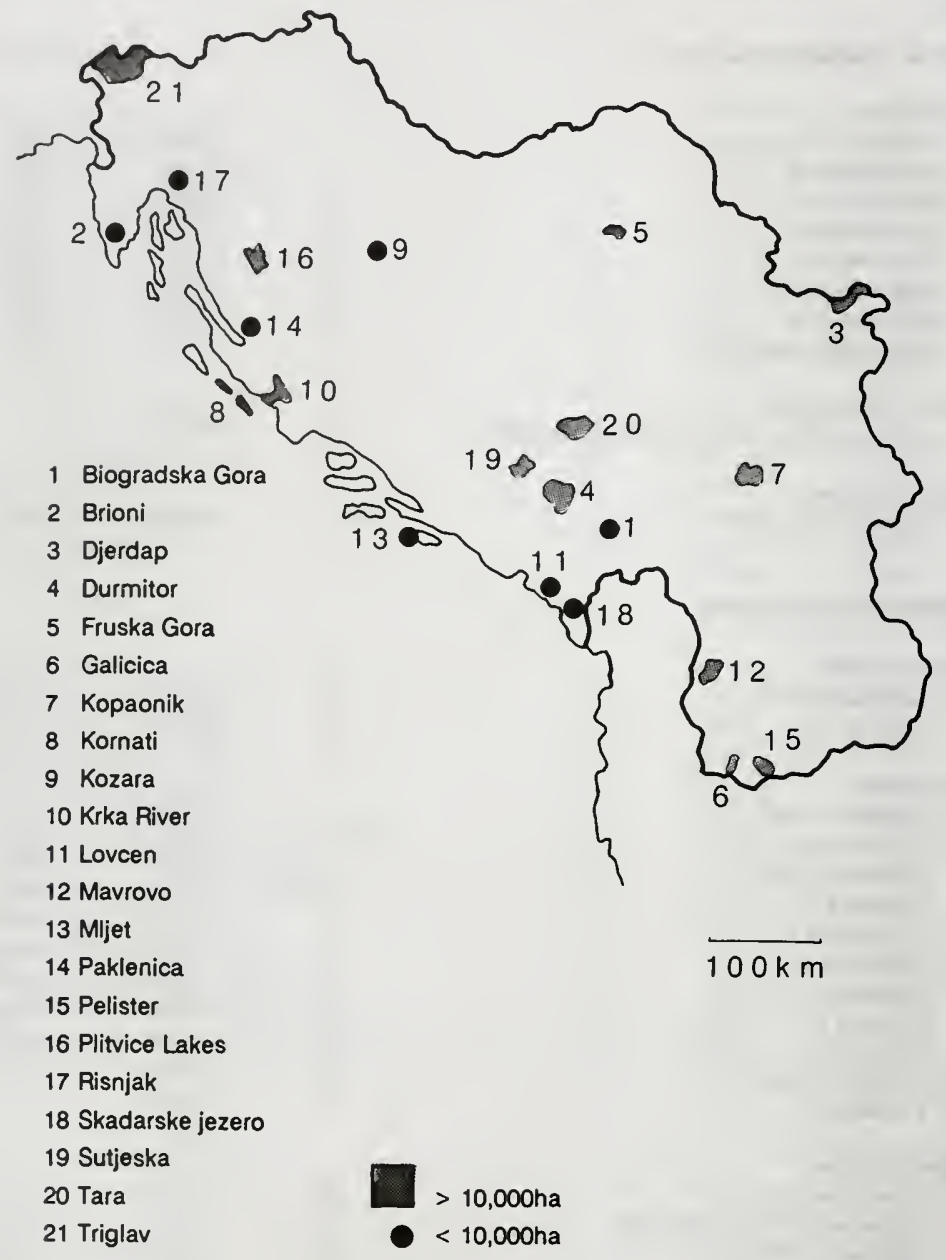


Ukrainian S.S.R., contd ..

Biosphere Reserves

Askaniya-Nova Zapovednik

IX

33,307

1985

Chernomorskiy Zapovednik

IX

87,348

U.S.S.R. - Uzbekistan S.S.R.

National Parks

Uzbekistan People's Park NP

II

31,503

1978

\section{Zapovedniki}

Baday-Tugay Z

Chatkal'skiy Z

Gissarskiy Z (Kyzylsuyskiy \& Mirakinskiy)

Kitabskii Z

Kyzylkumskiy Z

Nuratinskiy $Z$

Suzkhanskiy Z

Zaaminskiy $\mathbf{Z}$

Zeravshanskiy $\mathbf{Z}$

$\begin{array}{rr}5,929 & 1971 \\ 35,686 & 1947 \\ 87,538 & 1983 \\ 5,378 & 1979 \\ 10,141 & 1971 \\ 22,537 & 1975 \\ 28,014 & 1986 \\ 15,600 & 1959 \\ 2,352 & 1975\end{array}$

\section{YUGOSLAVIA}

\section{National Parks}

Biogradska Gora NP

Brioni NP

Djerdap NP

Durmitor NP

Fruska Gora NP

Galicica NP

Kopaonik NP

Kornati NP

Kozara NP

Krka River NP

Lovcen NP

Mavrovo NP

Mljet NP

Paklenica NP

Pelister NP

Plitvice Lakes NP

Risnjak NP

II

V

V

II

V

II

II

II

V

II

II

II

II

II

II

II

V

II
3,400

4,660

63,500

33,000

25,398

22,750

11,800

22,400

3,375

14,200

2,400

73,088

3,100

3,617

12,500

19,172

3,014
1952

1983

1983

1952

1960

1958

1981

1980

1967

1985

1952

1949

1960

1949

1948

1949

1953 
Yugoslavia, contd ...

Sara NP

Skadarske jezero NP

Sutjeska NP

Tara NP

Triglav NP

$\begin{array}{lll}\text { II } & 39,000 & 1986 \\ \text { II } & 40,000 & 1983 \\ \text { II } & 17,250 & 1965 \\ \text { II } & 19,175 & 1981 \\ \text { II } & 84,805 & 1981\end{array}$

Nature Reserves

Bijele i Samarske Stijene NR

Deliblatska Pescara NR

Hajducki i Rozanski Kukovi NR

Jorgov kamen NR

Kopacki Rit NR

Korab NR

Kotorsko Risanski Zaliv NR

Malostonski Zaljev NR

Neretva Delta NR

Obedska Bara NR

Obedska bara Kod Kupinova III NR

Ohrid (Ohridsko) jezero NR

Otok Krk Rta Glavine do Uvale Mala Luka NR

Planina Vodno NR

Prasuma perucica NR

Senecka planina NR

Veliki i Mali Strbac ra Trajonovum tablom NR

Zvijezda NR

I

V

IV

I

IV

V

I

IV

V

IV

IV

IV

IV

IV

IV

1,500

1988

1967

1988

2,601

12,000

10,389

1,200

17,501

1979

1983

1968

1968

1958

1969

1970

1954

1988

1975

1950

1,124
2,007

$\begin{array}{rr}\text { III } & 1,600 \\ \text { I } & 1,400\end{array}$

1968

1959

2,730

1970

5,285

1967

23,000

1958

1977

17,680

4,301

1988

1,000

1970

Suma od Krivulj na Jakusici NM

Landscape Parks

Robanov Kot LP

Topla LP

Velebit RNaP

Vidova gora LP

Zvecevo na papuku LP

$\begin{array}{rr}\text { V } & 1,580 \\ \text { V } & 1,345 \\ \text { VIII } & 200,000 \\ \text { V } & 1,800 \\ \text { V } & 2,586\end{array}$

1987

1966

1981

1970

1966 
Yugoslavia, contd ...

Historical Sanctuaries

Selo Trsic i okalina marastira HS

v

1,308

1965

Regional Nature Parks

Biokovo RNaP

Gornje Podunavljc RNaP

Grmija RNaP

Kopacki Rit (Kopacevo Marshes) RNaP

Palic-Ludas RNaP

Panonija RNaP

Rajac RNaP

Resava RNaP

Stari Begej RNaP

Suboticka suma RNaP

Tribevic RNaP

Visacke planine RNaP

Zahorina RNaP

Zvijezda na Planini Tara RNaP

$\begin{array}{rrr}\text { V } & 19,550 & 1981 \\ \text { V } & 10,325 & 1982 \\ \text { IV } & 1,126 & 1987 \\ \text { VIII } & 10,510 & 1976 \\ \text { V } & 6,360 & 1982 \\ \text { VIII } & 3,937 & 1975 \\ \text { VIII } & 1,200 & 1963 \\ \text { V } & 10,000 & 1957 \\ \text { V } & 1,327 & 1986 \\ \text { VIII } & 4,431 & 1982 \\ \text { V } & 1,000 & 1954 \\ \text { VIII } & 4,177 & 1982 \\ \text { V } & 2,000 & 1954 \\ \text { V } & 1,893 & 1971\end{array}$

\section{Specially Protected Areas}

Brioni National Park and Commemorative Site

(SpPA)

SPA

Kornati Islands National Park (SpPA)

Krka National Park (SpPA)

Limski zaljev Nature Reserve (SpPA)

Malostonski Zaljev Nature Reserve (SpPA)

Mljet National Park (SpPA)

Neretva Delta Nature Reserve (SpPA)

Paklenica National Park (SpPA)

SPA

SPA

SPA

SPA

SPA

SPA

SPA

4,000

1983

6,900

1980

14,200

1985

1,473

1979

10,389

1983

4,619

1961

7,430

1954

3,616

1954

Biosphere Reserves

Reserve ecologique du Bassin de la Riviere Tara

IX

200,000

1976

Velebit Mountain

IX

150,000

1977

World Heritage Sites

Durmitor National Park

Kotor WHS

Ohrid

Plitvice Lakes National Park

$\begin{array}{rr}\mathrm{X} & 32,000 \\ \mathrm{XC} & 12,000 \\ \mathrm{X} & 38,000 \\ \mathrm{X} & 19,200\end{array}$




\section{IUCN - The World Conservation Union}

Founded in 1948, IUCN - the World Conservation Union - is a membership organisation comprising governments, non-governmental organisations (NGOs), research institutions and conservation agencies in 120 countries. The Union's objective is to promote and encourage the protection and sustainable utilisation of living resources.

Several thousand scientists and experts from all continents form part of a network supporting the work of IUCN's six Commissions: threatened species, protected areas, ecology, sustainable development, environmental law, and environmental education and training. The Union's thematic programmes include tropical forests, wetlands, marine ecosystems, plants, the Sahel, Antarctica, population and sustainable development and women in conservation. These activities enable IUCN and its members to develop sound policies and programmes for the conservation of biological diversity and sustainable development of natural resources.

\section{East European Programme}

IUCN's East European Programme was established in 1987 with financial support from the Rockefeller Brothers' Fund. The Programme has built up an uparalleled store of information on conservation issues in eastern, central and south-eastern Europe. Dissemination of this information is being carried forward through the EEP Report and Research Series.

Further information on the Programme and its publications may be obtained from the IUCN Publications Unit, 219c Huntingdon Road, Cambridge, CB3 ODL, UK. 



\section{Published by IUCN}

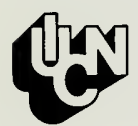

This book is part of

THE IUCN CONSERVATION LIBRARY

For a free copy of the complete catalogue please write to: IUCN Publications Unit, World Conservation Monitoring Centre, 219c Huntingdon Road, Cambridge, CB3 ODL, UK. 